DANIELA MANTOVANI TORDINO

\title{
V ING - RELAÇÕES HÍBRIDAS DAS IMAGENS AO VIVO NA CULTURA CONTEMPORÂNEA
}

\author{
Dissertação apresentada ao Programa de \\ Pós-Graduação em Artes Visuais, Área de \\ Concentração Poéticas Visuais, Linha de \\ Pesquisa Multimeios, da Escola de \\ Comunicação e Artes da Universidade de \\ São Paulo, como exigência parcial para \\ obtenção do Título de Mestre em Artes \\ Visuais, sob a orientação da Profa. Dra. \\ Sílvia Laurentiz.
}

SÃO PAULO 
Banca Examinadora 


\section{Resumo}

Este trabalho analisa a projeção e manipulação de imagens ao vivo no contexto da arte e tecnologia. As performances dos VJs - visual jockeys - têm sido cada vez mais requisitadas nos eventos direcionados à cultura eletrônica e as imagens geradas estabelecem relações híbridas com a música, o cinema, a videoarte e outras linguagens artísticas contemporâneas. A rápida expansão e ação desta forma de manifestação propulsionou a realização desta dissertação, que objetiva compreender essas relações com base na observação das apresentações, entrevistas estruturadas com agentes do meio e na leitura dos poucos textos existentes sobre 0 assunto, visto que a atividade de $V$ Jing é recente e aberta à experimentações que surgem a cada dia. É parte integrante deste trabalho um DVD com o vídeo "VJing: imagens da cena", que longe de ser uma experimentação artística, trata-se do registro de performances de VJing realizadas em casas noturnas, festivais e nos circuitos artísticos.

Palavras-chave - arte, vjing, vj, vídeo, imagens. 


\section{Abstract}

This work analyses the process of projecting and manipulating live images in the context of art and technology. VJs (visual jockeys) performances have been increasingly requested at electronic culture events and the generated images establish hybrid connections with music, cinema, video art and other contemporary artistic languages. The rapid increase of this kind of manifestation has incited the making of this dissertation, which aims at comprehending these connections based on observation of performances, interviews with the $\mathrm{VJ} \mathrm{s}$ and by reading the few existing texts about the subject, for $V J$ ing is recent and open to experiments that are held each day. A DVD with the video "VJing: images of a scene" is an essential part of the work and, far from being an artistic experimentation, it's a register of live visuals performances presented at clubs, festivals and artistic circuits.

Keywords - art, vjing, vj, video, images. 
Para meu pai, Cláudio, por me estimular a estudar, sempre.

Para minha mãe, Ozana, pelo incentivo incondicional.

Aos meus avós, Amadeu e Hosana, Nicola (in memorian) e Vera, por ensinarem tantas coisas que não se aprendem na escola.

Ao Kiko Ferraroni, companheiro para tudo e para toda a vida. 


\section{AGRADECIMENTOS}

À orientadora Silvia Laurentiz, pelas preciosas observações.

Aos VJ s Spetto e Bete Rum, responsáveis pela minha incursão ao universo do VJ ing.

A todos os VJS que colaboraram com este trabalho. 


\section{SUMÁRIO}

INTRODUÇÃO: 0 cenário de VJ ing na tecnocultura............................................... 8

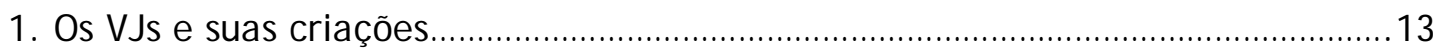

2. Antecedentes da projeção e manipulação de imagens ao vivo.............................27

3. Sob a ótica da visualidade

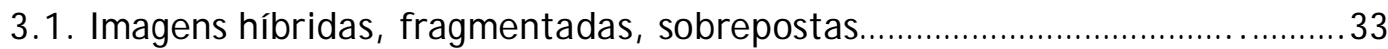

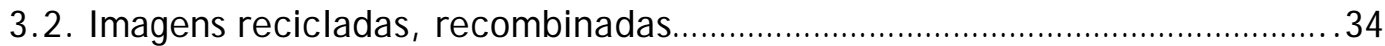

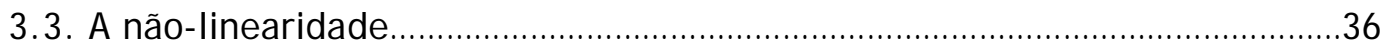

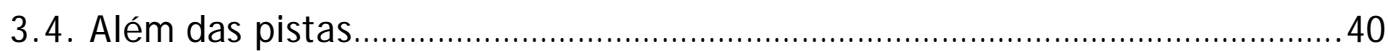

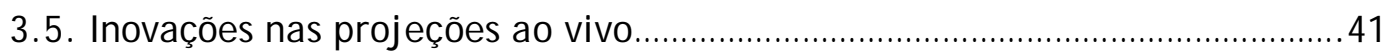

4. A linguagem musical atuando no processo

4.1. A tecnologia viabilizadora das performances.............................................. 45

4.2. A recriação do espaço .............................................................................49

4.3. 0 jazz e o improviso durante as apresentações..........................................49

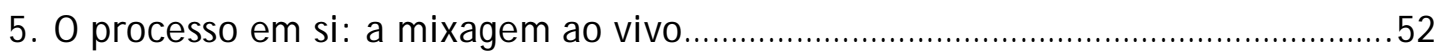

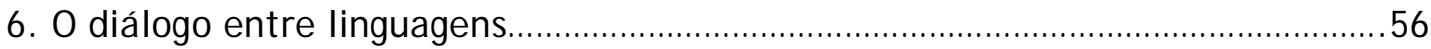

CONSIDERAÇÕES FINAIS.....................................................................

REFERÊNCIAS BIBLOGRÁFICAS.........................................................72

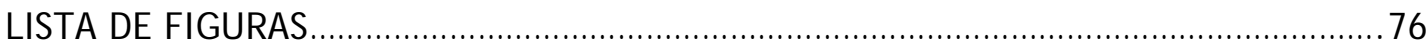

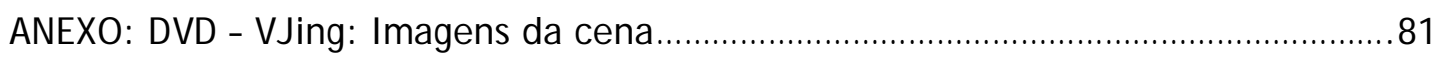




\section{Introdução: o cenário de $\mathbf{V}$ ing na tecnocultura}

Obras que utilizam o vídeo em suas elaborações são recorrentes desde a década de 1960, mas foi a partir dos anos noventa, com a maior facilidade para aquisição de equipamentos e programas, que as experimentações nessa área se intensificaram. A evolução tecnológica e o barateamento de hardwares e softwares alteraram 0 rumo das artes e de seus criadores, que passaram a usufruir suas múltiplas possibilidades como jamais havia sido possível anteriormente. Trabalhos que antes só seriam realizáveis dentro de produtoras e estúdios equipadíssimos, passaram a ser viabilizados em estruturas menores, caseiras até. A digitalização permitiu que diversas artes como a música, a fotografia, o vídeo e o cinema, fossem mescladas na composição de uma única obra. Edmond Couchot afirma que "as técnicas de figuração numérica modificam a arte na medida em que são empregadas para controlar todas as imagens automáticas (fotografia, cinema, televisão), pois estas serão transmutadas em números para poderem ser registradas, tratadas, difundidas, conservadas e manipuladas" (COUCHOT, 1993:45).

Nessa conjuntura, a música eletrônica de pista conquistou seu espaço e proporcionou a eclosão do trabalho do VJ - visual jockey ${ }^{1}$-, responsável pela projeção e edição ao vivo de imagens em clubes, raves, festivais e galerias. Além das atrações musicais, esses locais passaram a oferecer o improviso do vídeo ao vivo acompanhando o ritmo da música tocada pelo DJ. Segundo Arlindo Machado:

com o surgimento da cena techno, entramos numa nova fase de simbioses, até porque nesses ambientes musicais fortemente mediados por máquinas, não existe mais performance musical no sentido clássico dos termos, mas processamento técnico do som através da manipulação de sintetizadores e samplers, programação de computadores e a invocação de equipamentos eletrônicos cada vez mais próximos da tecnologia videográfica (MACHADO, 2000:184).

\footnotetext{
1 Paul Spinrad, em seu livro The VJ Book, define VJ como a abreviação de Video J ockey, uma contrapartida ao Disc Jockey, mas acredita ser Visual Jockey o nome mais apropriado (2005:13). Também é possível referir-se ao VJ como Visual J ammer, forma menos encontrada.
} 
Assim como os DJ S mixam suas músicas, durante as performances os VJs mixam imagens previamente selecionadas, que são manipuladas: distorcidas, sobrepostas, fundidas e acrescidas de efeitos, através de programas e uma mesa de edição. 0 nome VJ, criado no final da década de setenta por um grupo de videoartistas que se apresentavam na boate nova-iorquina Peppermint Lounge, surgiu por conta dessas semelhanças com a atividade do DJ. Mas há muito mais do que a simples tentativa de sincronia entre som e imagem. As características do espaço onde acontecem as apresentações, como seu tamanho, arquitetura, iluminação e a quantidade e disposição dos telões onde as imagens são projetadas, determinam 0 tipo de fruição do público. A combinação dessas variáveis evocam os sentidos e podem transformar o local em um ambiente propício à sinestesia, uma experiência imersiva. A atividade dos VJ s, como observa Patrícia Moran, "é um fenômeno do entretenimento e da invenção audiovisual que propõe e/ou é proposto em um momento histórico em que a arte e a comunicação procuram promover a estimulação sensório-motora" (MORAN, 2004:2).

No Brasil, o marco da consolidação ${ }^{2}$ da atividade de VJing foi a primeira e única edição do Red Bull Live Images ${ }^{3}$ realizada em setembro de 2002, em São Paulo e que contou com as performances ao vivo dos principais VJ $\mathrm{s}$ brasileiros em um galpão onde o público ficava rodeado pelas projeções. 0 evento trouxe visibilidade para o VJ ing, que estava restrito ao circuito underground da música eletrônica de pista, como raves, casas noturnas e festas. O Festival Eletronika de Novas Tendências Musicais ${ }^{4}$ também contribuiu para o crescimento da cena, por ser um dos primeiros festivais a incluir VJ s em sua programação. Em 2003, a organização do festival de música eletrônica Skol Beats contratou VJs para projetarem em todas as tendas onde se apresentavam os DJ s. A partir desse momento os eventos patrocinados por instituições privadas, preocupadas em associar a imagem de suas marcas à vanguarda tecnológica e à contemporaneidade, passaram a requisitar a

\footnotetext{
${ }^{2}$ As performances de VJ s no Brasil tiveram início em 1999/2000.

${ }^{3}$ O Red Bull Live Images contou com as apresentações de J odele Larcher (RJ), Spetto (SP), Embolex (SP), Bijari (SP), Lucas (RJ), Raimo (SP), Alexis (SP), Palumbo (SP) e Feitoamãos (BH).

${ }^{4}$ O Eletronika acontece desde 1999, em Belo Horizonte, idealizado por Aluizer Malab, Marcos Boffa e J efferson Santos.
} 
presença de VJs em festivais multimídia como o Nokia Trends, o TIM Festival e 0 Motomix. Paralelamente, os eventos alternativos nunca deixaram de existir, como por exemplo a festa TEMP ${ }^{5}$, que reúne DJ s, VJs, videomakers e performers. Em eventos patrocinados, os investimentos em equipamentos para projeções ao vivo costuma ser maior, viabilizando novas experimentações. Em contrapartida os VJ S às vezes precisam seguir regras impostas pelas empresas, como não veicular cenas incompatíveis com as imagens das marcas dessas instituições ou exibir seus logotipos durante as projeções.

Percebe-se as diferenças das propostas de cada VJ ao verificar-se suas referências, fontes de pesquisa, modos de captação e tratamento das imagens, sendo que muitas delas não são de autoria própria, mas baixadas da rede ou escaneadas. Como bem descreve Christine Mello, "trata-se de imagens integrantes do acervo universal das redes de informação interligadas da contemporaneidade" (MELLO, 2004:54). O videoartista e VJ Lucas Bambozzi assinala que faz sentido que essas imagens não tenham dono, já que vivemos em um mundo que permite a reprodução infinita. "Por outro lado, nesse terreno devassado, é a afirmação pontual de estéticas pessoais que gera algum diferencial" (BAMBOZZI, 2005:2). 0 desafio é transformar as referências acumuladas e esse acervo universal disponível em uma proposta estética consistente, uma vez que saber utilizar programas e equipamentos está ao alcance de todos. A democratização ocorrida por conta da revolução tecnológica permite ao amador ocupar a posição de criador,

dando a não importa quem a possibilidade de se exprimir realizando seus próprios documentos que ele ou ela pode ter a pretensão de qualificar como obras. 0 estudo desses objetos redobra a difícil questão do estatuto de seu autor e relança 0 debate inaugurado por Duchamp no início do século passado sobre a fronteira entre arte e não arte (POISSANT, 2003:118).

\footnotetext{
${ }^{5}$ As edições da Temp - Temporary Eletronic Musik Party, organizadas por Bruno Tozzini e Daniel Gonzáles eram realizadas em espaços urbanos alternativos e contestavam a elitização e 0 conformismo das festas de música eletrônica bancadas por grandes empresas.
} 
Assim como em outras vertentes da arte tecnológica, nem todas as criações são relevantes. Enquanto alguns VJS se contentam em utilizar somente imagens baixadas da rede e serem meros manipuladores de softwares, outros buscam alicerçar seus trabalhos na mistura de linguagens (vídeo, animação, fotografia), na videoarte ou resgatam elementos da performance.

O objetivo deste trabalho, porém, não é classificar as obras dos VJ S, mas analisar as questões pertinentes às imagens produzidas e suas relações, no contexto de uma época marcada pela fragmentação, recombinação, efemeridade $e$ multisensorialidade, onde o VJ desempenha um papel de canalizador de tendências. Para o embasamento desta pequisa, buscou-se a teoria existente sobre arte e tecnologia, além dos escassos textos acadêmicos sobre o assunto.

Esta dissertação foi dividida em seis capítulos: o primeiro capítulo, "Os VJ s e suas criações", apresenta os pioneiros do VJing no Brasil e outros mais novos na cena. Através da descrição dos métodos de produção das imagens e informações obtidas em entrevistas, percebe-se as diferenças entre os trabalhos mencionados.

O segundo capítulo, "Antecedentes da projeção e manipulação de imagens ao vivo", traz as influências de invenções como os color organs, da história da animação - como as criações de Oskar Fischinger e Normam McLaren -, do início do cinema, da arte de performance e a contribuição de artistas como Nam J une Paik para o surgimento desta nova forma de manifestação artística.

O terceiro capítulo, "Sob a ótica da visualidade", analisa as questões da imagem pertinentes ao VJing e aborda conceitos como hibridização, recombinação, autoria, narratividade, entre outros. Apresenta também algumas performances fora do ambiente das pistas e inovações nos suportes e formatos de projeções. 
O quarto capítulo, "A linguagem musical atuando no processo", evidencia as relações entre as imagens e a linguagem musical que permeiam a projeção e manipulação de imagens ao vivo, como na tecnologia utilizada, nas influências de alguns estilos musicais na recriação do espaço onde ocorrem as apresentações e no improviso, também associado ao jazz.

O quinto capítulo, "O processo em si: a mixagem ao vivo" apresenta as características que determinam 0 tipo de fruição do público durante as apresentações, como acontece a participação do espectador e o que faz com que as performances de VJing sejam únicas.

O sexto capítulo, "O diálogo entre linguagens", estabelece relações do VJing com outras linguagens artísticas contemporâneas, como a arte sonora, o grafitti eletrônico, a web art, mobile art, intervenções urbanas, games e instalações interativas.

As considerações finais apontam para outros modos de interação do público durante as performances e para a reconfiguração do VJing em novas manifestações artísticas, fruto do diálogo constante com as linguagens mencionadas no sexto capítulo. 


\section{Os V s e suas criações}

A seleção dos VJS foi realizada a partir de uma matéria escrita para a Revista Simples, em maio de $2003^{6}$. Os entrevistados eram os principais expoentes do VJing naquele momento. Com o crescimento da cena, novos VJs surgiram e foram incluídos nesta dissertação.

Alexis Anastasious é considerado pelos demais VJs o pioneiro na arte de VJing no Brasil. Ex-estudante de Relações Internacionais em Brasília, decidiu ser VJ após conferir a apresentação multimídia do grupo alemão Kraftwerk ${ }^{7}$ no Free Jazz 98, em São Paulo, marcada pela sincronia das músicas com as imagens projetadas. No ano seguinte, começou a se apresentar. "Eu não tinha noção alguma de edição de vídeo, usava duas VHS e uma picapezinha que soltava imagens psicodélicas, era bem tosco", conta ${ }^{8}$. Atualmente utiliza equipamentos sofisticados como DVJ ${ }^{9}$, mixers de vídeo, áudio e está em constante pesquisa de novos formatos e suportes para projeções. Entre suas referências está o cinema mudo, que considera o oposto do trabalho de VJing, já que nele o músico criava a trilha em cima do filme, enquanto o VJ produz as imagens em cima da música.

\footnotetext{
6 "Império dos Sentidos" in Revista Simples, n21, edição mai/ jun 2003, minha autoria.

7 www. kraftwerk.com, acessado em 20.jan. 2008.

8 Declaração concedida para a matéria "Império dos Sentidos" - Revista Simples, nำ21, edição mai/ jun 2003.

${ }^{9}$ O DVJ , da Pioneer, possibilita a manipulação de DVDs como discos de vinil e será melhor abordado no capítulo 4.
} 


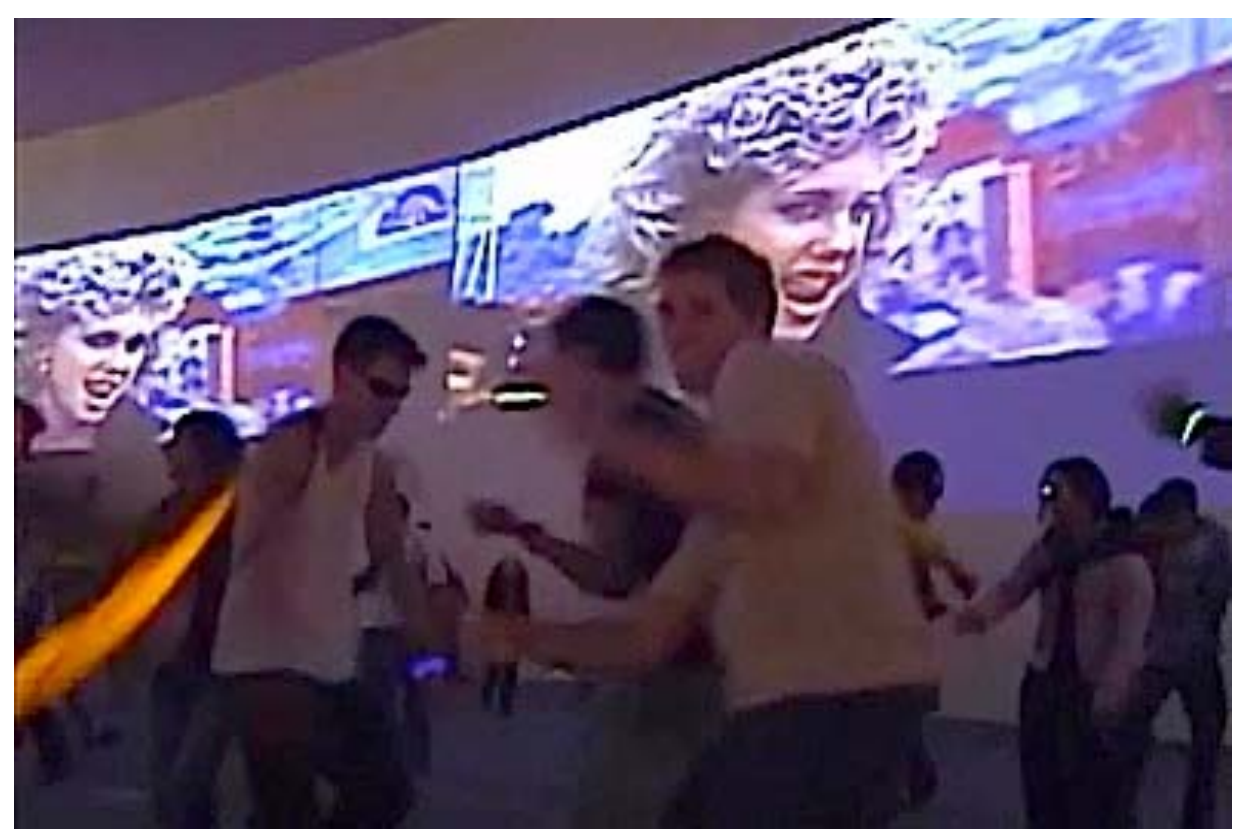

Figura 1 - VJ Alexis: remix de filmes no Skol Beats 2006.

Já o programador Ricardo Lara ou Spetto, como é conhecido, começou a se apresentar como VJ no circuito underground, acompanhando DJ s de techno. Ele construiu um software para VJing, o VRStudio ${ }^{10}$, que associa as imagens selecionadas no banco de dados às teclas do computador, possibilitando assim a "digitação" dessas imagens e sua manipulação. Há nas projeções de Spetto uma certa preocupação em subversão da ordem, seja através de mensagens a favor da pirataria ou de imagens que ridicularizem personalidades como o presidente George W. Bush, utilizando para isso todo o ambiente digital que o envolve: imagens da web, TV e "lixo eletrônico". Spetto acredita que as cores exercem influência na reação do público e faz uso delas para controlar o que ele chama de "temperatura da pista" ${ }^{11}$.

\footnotetext{
${ }^{10}$ Disponível no site www.visual radio.com.br, acessado em 20.jan. 2008.

${ }^{11}$ Declaração concedida para a matéria "Império dos Sentidos" - Revista Simples, no21, edição mai/ jun 2003.
} 


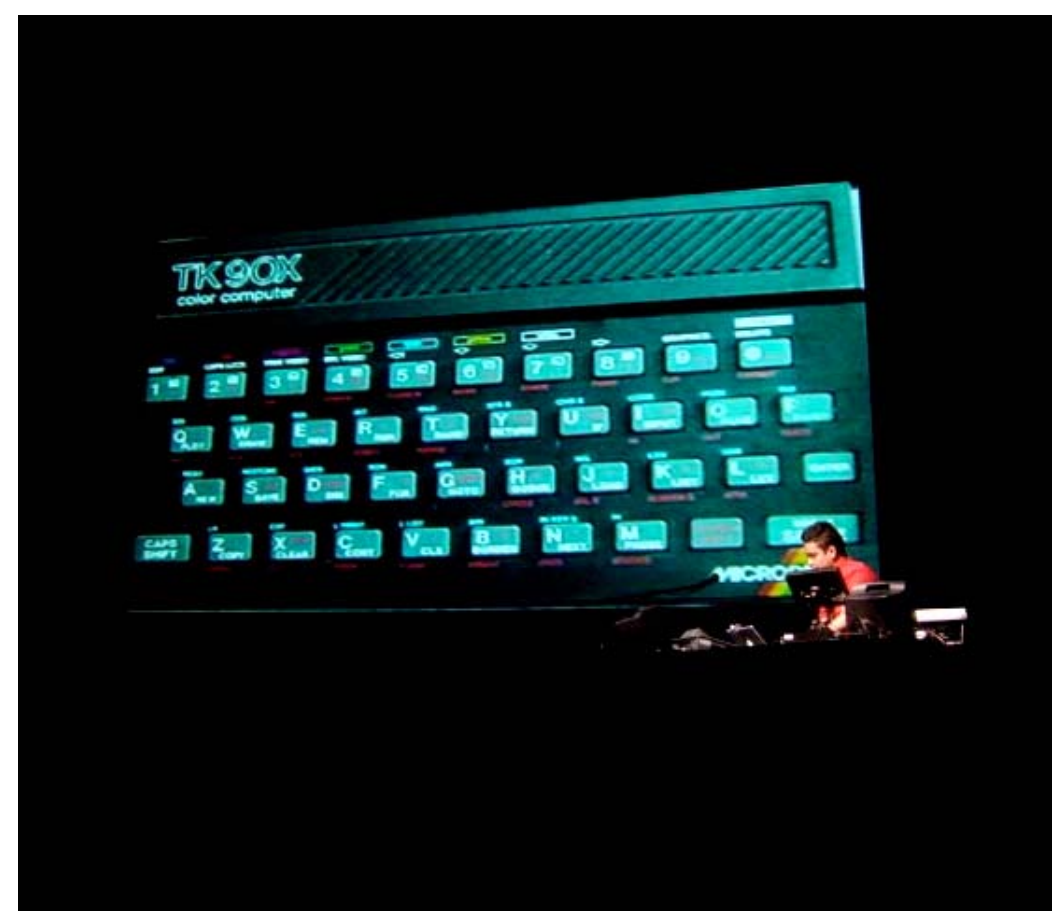

Figura 2 - VJ Spetto no Instituto Cultural Itaú, 2005.

Atualmente fora da cena de VJing, o artista plástico e multimídia Ângelo Palumbo possui trabalho marcante e diferenciado. Sua estréia como VJ foi na rave Ecosystem 2001, em Manaus. Para ele, o VJ é um “tocador de imagens" ${ }^{12}$ e em suas obras utiliza mais o scanner do que a captação em vídeo. Sua apresentação é iconográfica, uma descarga de imagens de cores fortes, que acompanha a velocidade da música e provoca uma comunicação subliminar, "bombardeando" os neurotransmissores e colocando em prática os conhecimentos adquiridos quando foi fundador e coordenador do Núcleo de Estudos e Pesquisas em Psicologia Virtual do Hospital Albert Einstein, em São Paulo.

${ }_{12}$ Declaração concedida para a matéria "Império dos Sentidos" - Revista Simples, no21, edição mai/ jun 2003. 


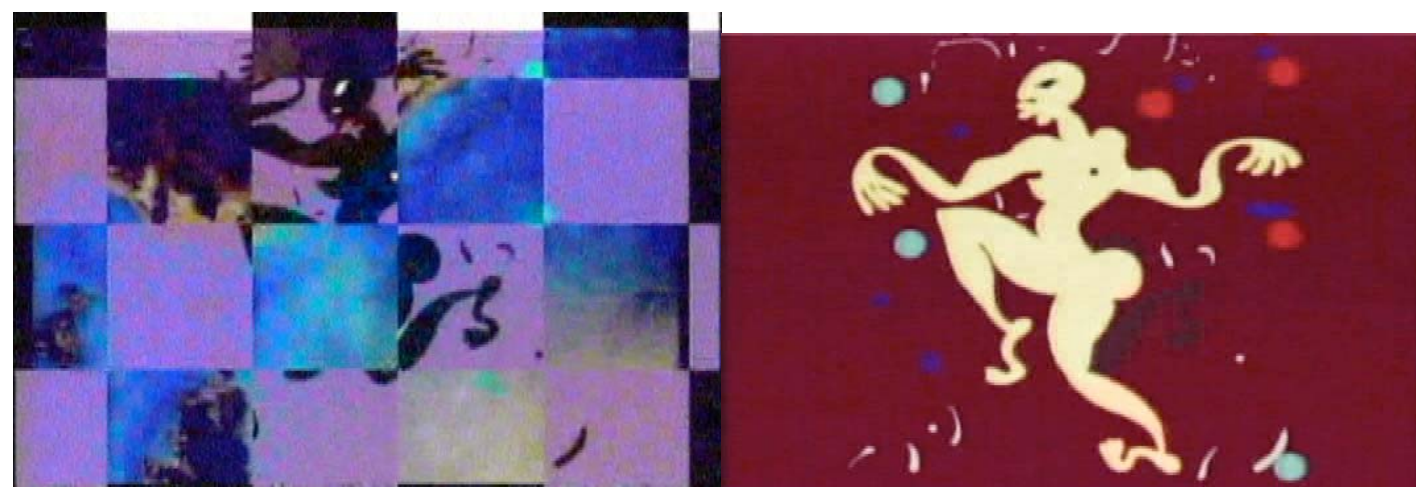

Figura 3 - Proj eção de Palumbo.

O artista Luiz Duva cria e realiza vídeos, documentários, vídeo-instalações e performances. Sua primeira apresentação como VJ foi em julho de 2000 no clube paulistano Lov.e, juntamente com o produtor Eraldo, do grupo musical Water Fronthouse. No Red Bull Live Images, onde foi curador, ele apresentou 0 impactante trabalho "Vermelho Sangue" ${ }^{13}$, que mostrava a imagem de um casal intercalada a imagens de vísceras, cenas de uma endoscopia realizada no próprio artista, uma verdadeira "viagem interior". Sua dupla foi o músico experimental Wilson Sukorski. Ele conta que levou as cenas pré-gravadas, fizeram alguns ensaios e, no momento da apresentação, se comunicavam através de olhares. Duva escreve as cenas, grava as imagens e manipula as cores no computador. Para ele o VJ utiliza o ambiente sensorial proporcionado pela música para a projeção. "Não há narrativa e sim, a desconstrução de um movimento", explica ${ }^{14}$.

\footnotetext{
${ }^{13}$ Trecho disponível em vídeo no site: www. liveimages. com. br, acessado em 20.jan. 2008.

${ }^{14}$ Declaração concedida para a matéria "Império dos Sentidos" - Revista Simples, no21, edição mai/jun 2003.
} 


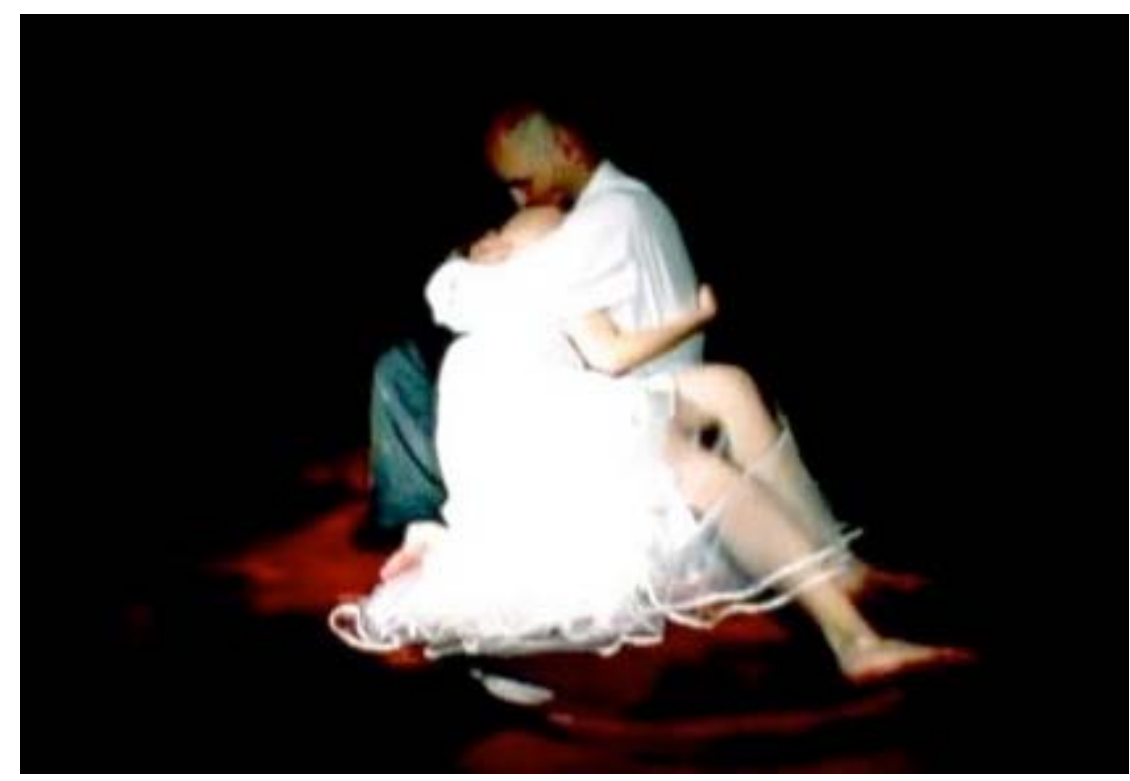

Figura 4 - "Vermelho Sangue", de Duva.

Coletivos são comuns na cena de VJing. O Embolex se formou em 2000 e já se apresentou ao lado de diversos DJ s na Europa e no Brasil. Fernão Ciampa acredita que os conhecimentos de cada integrante, quando somados, viabilizam obras que não seriam realizáveis por uma única pessoa. Como referências do grupo, cita os filmes "Bang Bang", de Andrea Tonacci e "O Homem da Câmera", de Dziga Vertov $^{15}$. Seus trabalhos são totalmente baseados na edição ao vivo, onde as seqüências de imagens já tratadas - gravadas com participação de atores ou captadas das ruas ou TV -, só adquirem sentido no momento da mixagem. 0 grupo inovou a cena paulistana em 2003 com o projeto Embolex Whiteout, realizado na boate underground Hole. No local pequeno e escuro, diversos VJs se revezavam para projetar em três telões estrategicamente posicionados na pista de dança. Não havia como fugir do impacto das imagens atreladas às batidas marcadas do techno em alto e bom som.

${ }^{15}$ Declaração concedida para a matéria "Império dos Sentidos" - Revista Simples, no21, edição mai/jun 2003. 


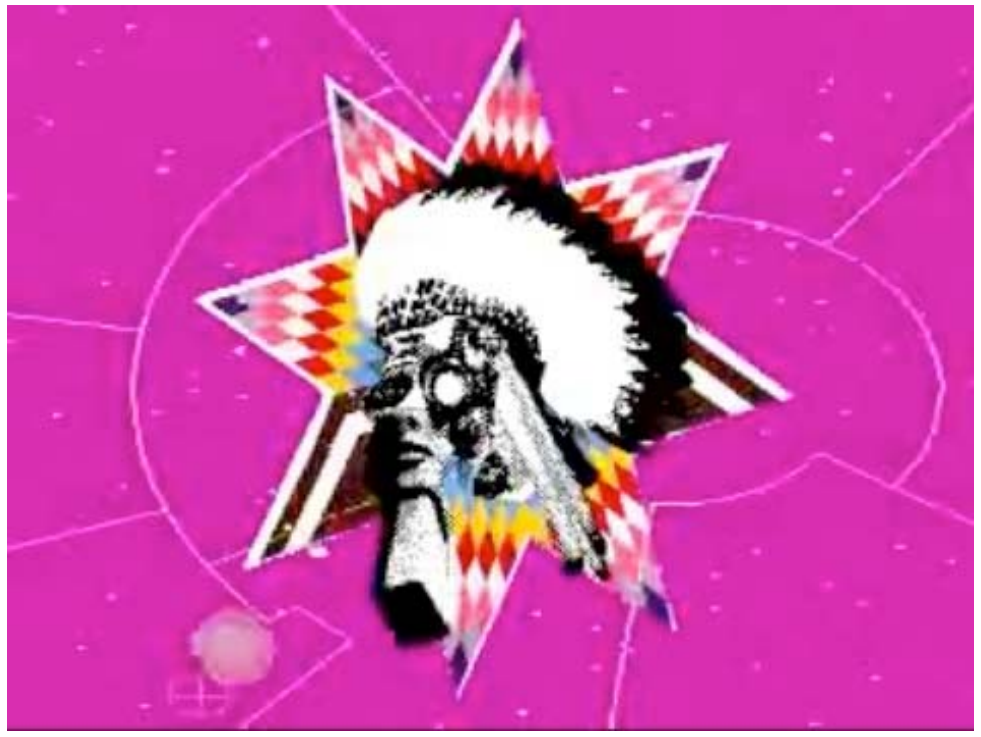

Figura 5 -Embolex no show do Afrika Bambaataa, Skol Beats 2007.

Outro coletivo, o Bijari, se formou em 1997 através de um grupo de amigos alunos da FAU-USP, que alugaram uma casa para servir de ateliê e estúdio de produção multimídia. As imagens utilizadas em suas apresentações são todas de autoria do grupo, que utilizam softwares como Final Cut, After Effects, Flash, Streamline e 3D Studio. Além de participarem dos principais festivais de música do país, como Motomix, TIM Festival e Skol Beats, estiveram presentes na 8a Bienal de Havana, em 2003, e na 1a Bienal do Fim do Mundo em Ushuaia (2004), onde exibiram trabalhos que incorporavam intervenção urbana e vídeo ao vivo ${ }^{16}$. No Red Bull Live Images exibiram projeções com os temas "Realidade Transversa", sobre o trabalho informal e "Antipop", que questionava a glamurização. Vendedores de rua e motoboys também participaram da performance.

\footnotetext{
${ }^{16}$ www. bijari.com.br, acessado em 20.jan. 2008.
} 


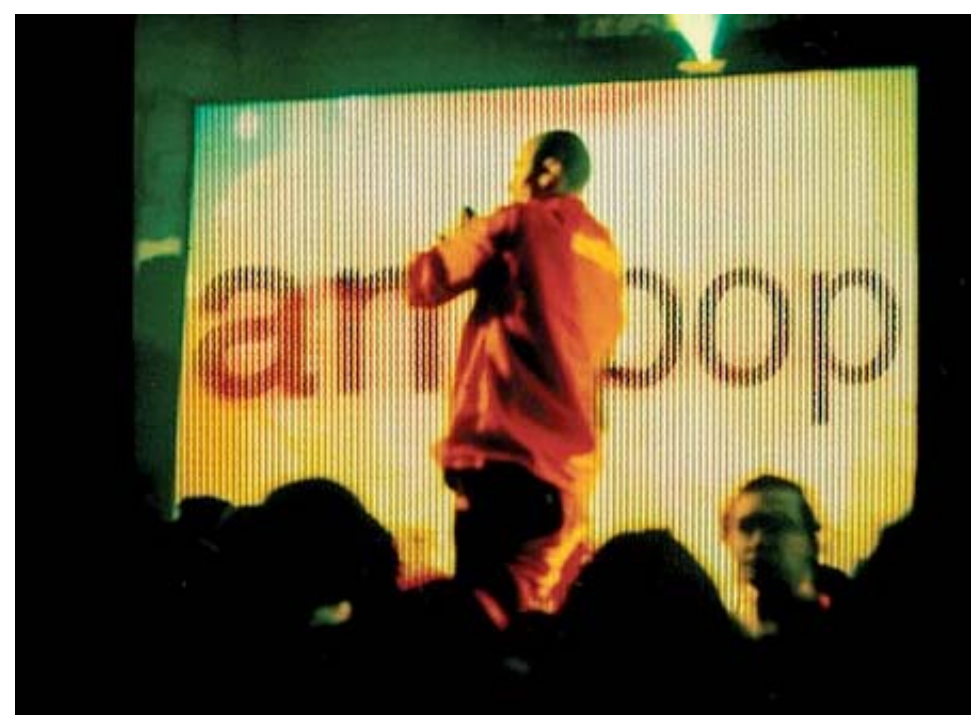

Figura 6 - Proj eção do Bijari no Red Bull Live Images

Mais um representante do trabalho em grupo, o coletivo mineiro feitoamãos/FAQ é formado por profissionais que trabalham há mais de dez anos com vídeo em atividades comerciais, produções artísticas e autorais, entre eles, o videoartista Lucas Bambozzi, também autor de artigos sobre VJing. Nesse tempo, eles puderam acompanhar todo o desenvolvimento tecnológico da edição. Buscam realizar trabalhos em arte eletrônica de forma coletiva, com a participação de convidados e misturam imagens gravadas e digitalmente processadas com textos de autoria própria ou não. Em performance realizada na abertura do Festival Internacional de Curta-Metragens de Belo Horizonte, em julho de 2001, eles conectaram quatro computadores a quatro projetores e, através de uma mesa de corte, remontaram o filme "O Homem da Câmera", de Vertov, ao vivo". Para Bambozzi, há neste filme uma "fina sintonia com as linguagens do universo digital, que se utiliza de layers e sugere o hipertexto, o fragmento, a repetição, a reciclagem e a simultaneidade" (BAMBOZZI, 2003:63). Em setembro de 2005 apresentaram "Carro-Bomba: guia anti-pânico e inversões rotativas" no 15 o FILE $^{18}$, misto de performance e vídeo ao vivo, onde o público ficava em meio às explosões de bombinhas enquanto conferia as imagens e mensagens projetadas nos telões.

\footnotetext{
${ }^{17}$ Trecho da performance disponível no www. feitoamaos. com. br, acessado em 20.jan. 2008.

${ }_{18} 015$ o Festival de Linguagem Eletrônica aconteceu em setembro de 2005, em São Paulo, sob a curadoria de Ricardo Barreto e Paula Perissinotto.
} 


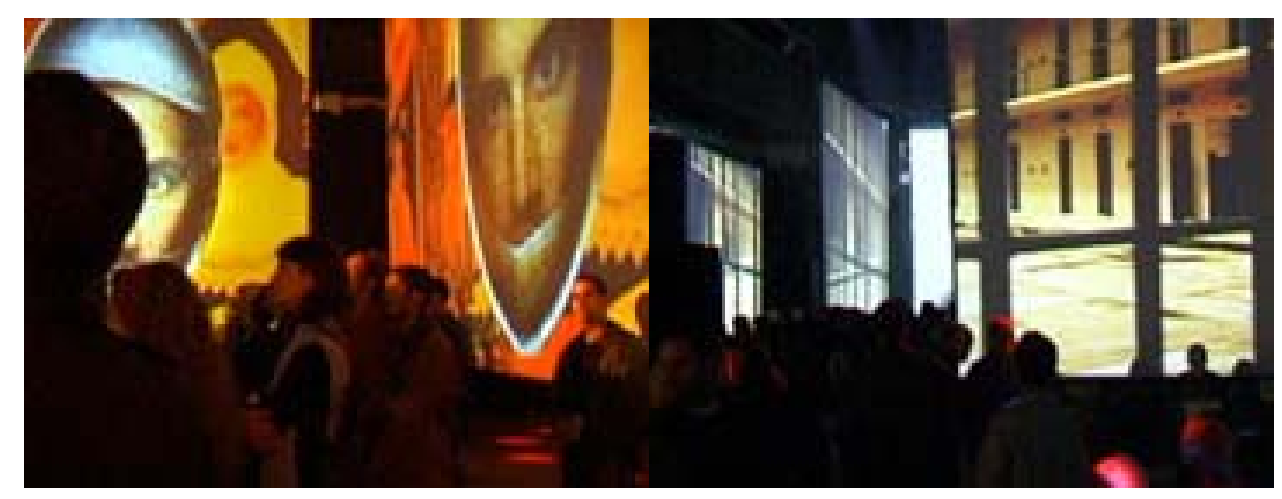

Figura 7 - "Dziga Vertov reenquadrado", do Feitoamãos/ FAQ

Mestre do corte ao vivo com várias câmeras simultâneas, o diretor de TV carioca Jodele Larcher também atua como VJ. Fez carreira na Rede Globo, onde dirigiu novelas, mais de cem videoclipes para o programa Fantástico e, em 2001, comandou a transmissão ao vivo do Rock in Rio III, captada por trinta e quatro câmeras. Atualmente comanda a produtora Innova e a Azóia Lab ${ }^{19}$, laboratório de criação de artes visuais, multimídia e manipulação de imagens ao vivo. 0 trabalho "Arpoador", uma animação com fotografias sob direção de Fernanda Ramos, faz parte da primeira compilação de vídeos de VJ s em DVD, o VJ BR, e foi premiado na categoria independente do 140 Gramado Cine Vídeo ${ }^{20}$.

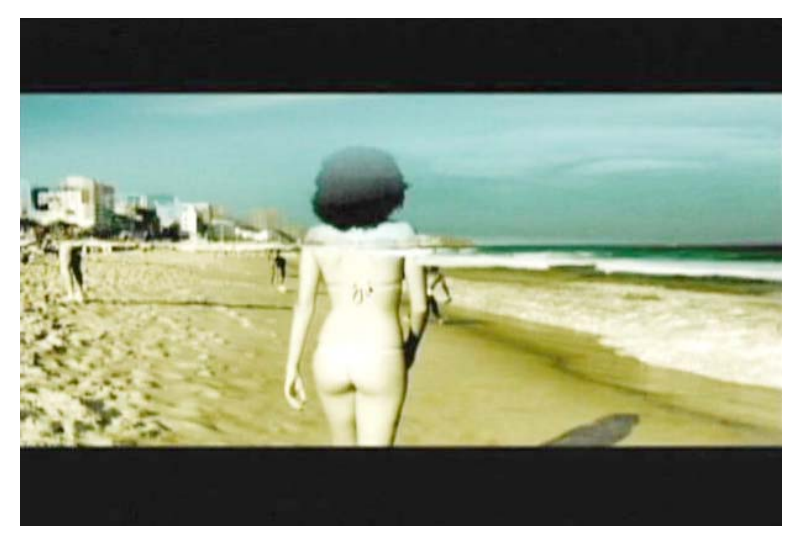

Figura 8 - "Arpoador", da Azóia Lab.

\footnotetext{
${ }^{19} \mathrm{http}$ :// inova.tv, acessado em 20. jan. 2008.

${ }^{20}$ O 140 Gramado Cine Vídeo, realizado em agosto de 2005, teve o júri formado por Pedro Zimmermann e J aime Lerner.
} 
O coletivo Desconstrução, de Brasília, formou-se em 2003 e seus três integrantes possuem experiências profissionais bem diversificadas: design, administração de empresas e engenharia de redes. A maioria das imagens utilizadas nas projeções são criadas no computador ou baixadas da rede e tratadas. Um dos componentes do grupo, o VJ Erms, compara o processo ao ato de cozinhar: "pega uma imagem, mistura com outra, experimenta, joga outra em cima, renderiza, prova de novo. Ficou bom, vai para o banco de imagens, ficou ruim, vai para a lixeira" ${ }^{21}$. No início as projeções aconteciam com maior frequência na cena eletrônica, mas com 0 tempo o trabalho se diversificou e começaram a se apresentar em shows de artistas como Nação Zumbi, Cordel do Fogo Encantado, Mundo Livre, Jorge Ben, entre outros. Erms acredita que nos shows há menos improvisação, mas a sincronia entre som e imagem é maior. Uma vez que se sabe com antecedência quais músicas serão tocadas, é possível compor previamente as imagens que melhor se adequam a cada uma delas.

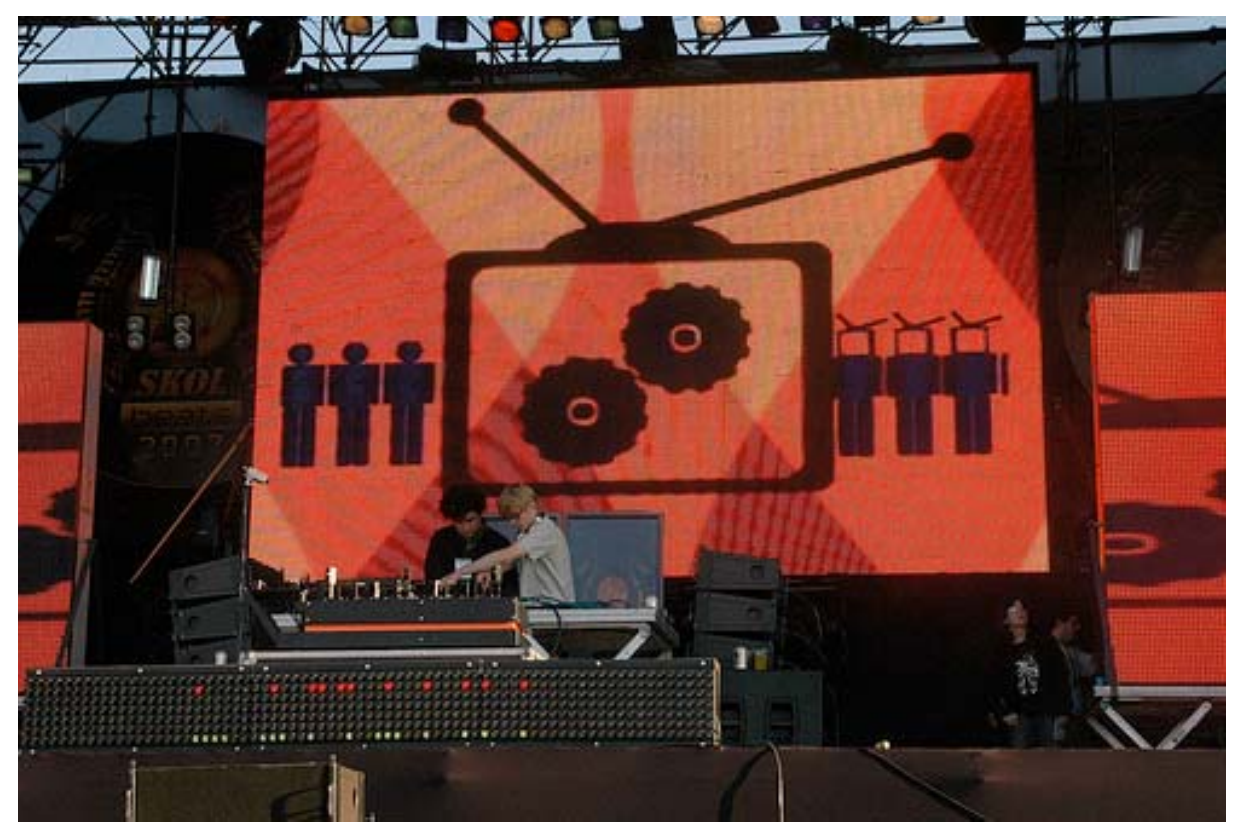

Figura 9 - Coletivo Desconstrução, show do Simian Mobile Disco no Skol Beats 2007.

\footnotetext{
${ }^{21}$ Declaração em entrevista concedida em 06 de novembro de 2007, pela internet.
} 
Enquanto os integrantes do Desconstrução utilizam apenas imagens disponíveis na rede, o VJ Impar, como é conhecido o designer e músico Henrique Roscoe, de Belo Horizonte, opta por projetar imagens de sua autoria sem utilizar câmeras de vídeo para a captação. Suas imagens são inteiramente criadas no computador ou desenhadas à mão e escaneadas. Formas abstratas e desenhos vetoriais constituem a base do seu trabalho. Além de acompanhar DJs na cena musical eletrônica, Impar se apresenta juntamente com 3nity (Tadeus Mucelli) no projeto audiovisual $A D D D^{22}$, surgido com o intuito de complementar a relação entre audição e visão, buscando total sincronia entre som e imagem. Nas projeções ao vivo, formas geométricas e não figurativas inspiradas no Construtivismo Russo, Expressionismo Abstrato e Neo-Plasticismo, se movem de acordo com ondas sonoras e sinais eletrônicos digitais gerados em software específico para produção musical.

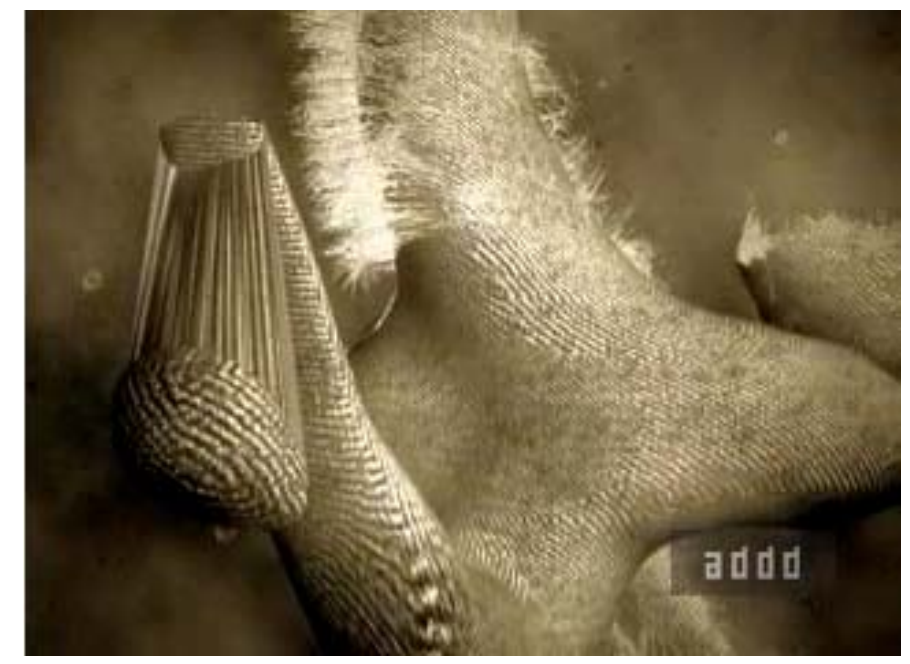

Figura 10 - "Estofado robô felpudo", do proj eto audiovisual ADDD.

A proposta do coletivo Laborg é proporcionar uma experiência multisensorial através da projeção de paisagens visuais, sem 0 uso de programas ou computadores. A maneira que seus integrantes criam as imagens é inusitada. Substâncias comuns como água, óleo e pigmentos são despejadas em aquários e as imagens resultantes dessas misturas são captadas por câmeras de vídeo, que por

\footnotetext{
${ }^{22}$ www.addd.com. br, acessado em 20.jan. 2008.
} 
sua vez são conectadas a um mixer para a edição ao vivo. Para conseguir os efeitos desejados o Laborg faz uso, entre outros aparatos, de uma lente macro e iluminação apropriada. Batidas no aquário, injeção de substâncias com seringas e zoom com a câmera são recursos para que haja sincronia com a música. As imagens obtidas são formas orgânicas: bolhas, jatos, gotas, formas abstratas, explosões de cores e texturas que revelam a beleza presente nos detalhes e na simplicidade. 0 Laborg se apresentou pela primeira vez no FILE Hipersônica $2005^{23}$ como um projeto audiovisual, com timbres e samplers obtidos de instrumentos acústicos e percussão corporal, editados e seqüenciados para acompanhar as imagens. Outros trabalhos ${ }^{24}$ foram realizados especialmente para serem exibidos em cinemas ou teatros, exigindo maior atenção do público.

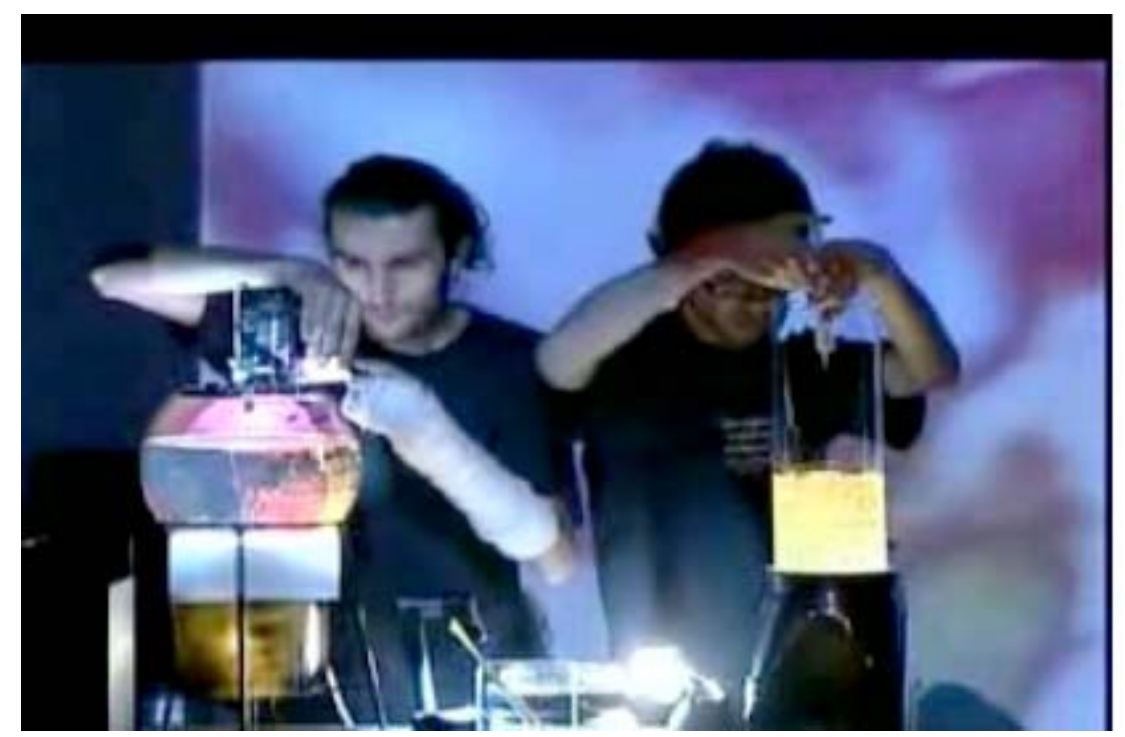

Figura 11 - Produção das imagens durante apresentação do Laborg, Hipersônica 2006.

${ }^{23}$ O Hipersônica fez parte da programação do 15 Festival de Linguagem Eletrônica realizado em setembro de 2005, em São Paulo e foi coordenado por Daniel Gonzáles.

${ }^{24}$ Disponíveis no http:// myspace. com/laborg, acessado em 20.j jan. 2008. 
Apresentações audiovisuais, também denominadas AV sets, são cada vez mais comuns na cena de VJing brasileira. Ao invés de acompanharem DJ $s$ em suas performances, neste tipo de trabalho os artistas são protagonistas de um espetáculo audiovisual, mixando sons e imagens ao vivo. Normalmente são realizadas por uma dupla ou um coletivo, como nos casos dos já citados ADDD e Laborg - onde integrantes de diversas áreas se complementam -, mas também podem ser protagonizadas por uma só pessoa, no caso dela ser DJ e VJ, por exemplo. Esses sets costumam oferecer maior sincronia entre áudio e vídeo, pois são frutos de um trabalho conjunto e há conhecimento prévio do que será executado, diferentemente do que ocorre em uma pista de dança, onde o VJ tenta acompanhar as batidas das músicas sem saber 0 que 0 DJ irá tocar. As apresentações de artistas consagrados no exterior inspirou os VJ $\mathrm{S}$ brasileiros a experimentarem esse caminho. Três dos VJ s presentes na lista dos Top $20 \mathrm{VJ} s$ do mundo eleitos pela revista DJ Mag ${ }^{25}$, em 2005, exibiram seus trabalhos por aqui: as duplas Cold $\mathrm{Cut}^{26}$, Ecletic Method ${ }^{27}$ e Addictive TV ${ }^{28}$. Na apresentação do Addictive TV, seus integrantes mixaram o filme "Cidade de Deus" 29 ao vivo e a simultaneidade da música com as imagens - cada clique da câmera fotográfica em uma cena do filme, cada tiro -, era impressionante. Essa sincronia é possível utilizando-se loops $^{30}$ de aúdio do filme para compor a música, além dos equipamentos usados durante o show como o DVJ, da Pioneer, que permite fazer scratches ${ }^{31}$ com as imagens.

\footnotetext{
${ }^{25}$ Revista inglesa especializada em música eletrônica de frequência mensal: www.djmag.com, acessado em 20.jan. 2008.

${ }^{26}$ O Cold Cut se apresentou no TIM Festival de 2005, realizado no Rio de J aneiro: www. coldcut. net

${ }^{27}$ Apresentação no Lov.e, em São Paulo, junho de 2006: www. ecleticmethod. net

${ }^{28}$ Performance no Mube, São Paulo - Motomix Festival, setembro de 2006: www. addictive.com

29 "Cidade de Deus" foi dirigido por Fernando Meirelles (Brasil, 2002).

${ }^{30}$ Trecho de música ou vídeo que se repete.

${ }^{31}$ Movimento de girar o vinil para frente e para trás com a ponta dos dedos, em velocidades variadas, como se "arranhasse" o disco. A criação do scratch é atribuída ao DJ Grand Wizard Theodore, em 1977.
} 


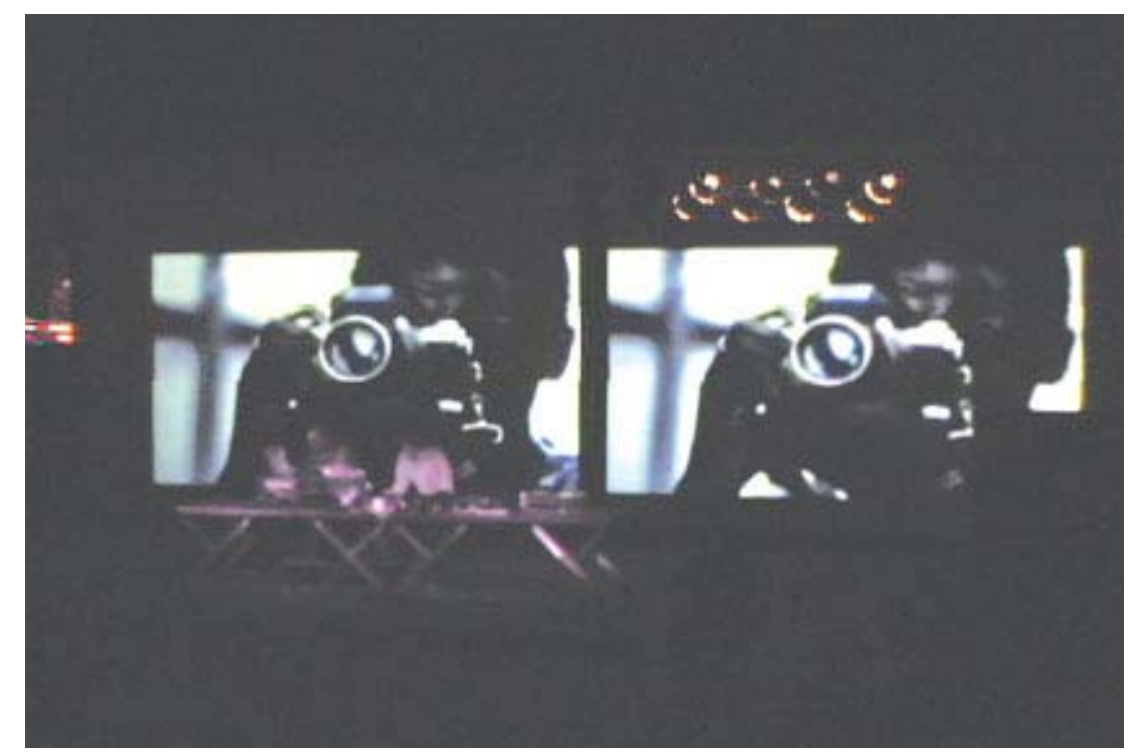

Figura 12 - Addictive TV mixa o filme "Cidade de Deus", no Mube, São Paulo.

O VJ e DJ brasileiro Robson Victor ${ }^{32}$ também optou por mixar filmes em algumas de suas performances, como a realizada no $F A D^{33}$. O filme escolhido foi "O lluminado" 34 . Para ele, "cada cena completa possui a mesma estrutura básica de uma música eletrônica: início, uma parte um pouco mais tensa, uma caída e a volta com força total". ${ }^{35}$ Ele criou a música utilizada na apresentação em cima dessa estrutura, ao mesmo tempo em que acrescentava efeitos no vídeo e no áudio.

Outros VJ S ainda são citados no decorrer desta dissertação. A VJ Bete Rum, como é conhecida Fabiana Bártholo, se apresenta desde 2002 em casas noturnas e festivais, entre eles o AVIT LA - realizado na Argentina em 2004 - e o Skol Beats. Também é fundadora do Coletivo Virtual ${ }^{36}$, uma proposta colaborativa baseada na web com o objetivo de mixar trechos de vídeos dos participantes durante as apresentações ao vivo - e que será melhor analisada na discussão sobre autoria.

\footnotetext{
${ }^{32}$ O VJ Robson Victor se apresenta desde 2004: www. robsonvictor.com. br, acessado em 20.jan. 2008. ${ }^{33}$ O FAD - Festival de Arte Digital foi realizado no Espaço Funarte - Casa do Conde, Belo Horizonte, em 29 de setembro de 2007.

34 "O lluminado" - título original "The Shining", foi dirigido por Stanley Kubrick (EUA, 1980).

${ }^{35}$ Declaração em entrevista concedida em 20 de novembro de 2007, pela internet.

36 Mais informações sobre o Coletivo Virtual estão disponíveis no capítulo 3.
} 
Kiko Ferraroni começou a projetar em 2005, após ser um dos selecionados para participar de sete dias de imersão no workshop Motomix, onde sob coordenação de profissionais das áreas de música, artes visuais e tecnologia, produziu em conjunto com os outros participantes as imagens exibidas na festa de encerramento do evento $^{37}$. Desde então se apresenta em eventos direcionados à música eletrônica, como o show da DJ francesa Miss Kittin ${ }^{38}$, onde projetou ao lado do VJ Spetto, o TIM Festival ${ }^{39}$, entre outros.

O VJ Albuk se apresenta desde 2003. É um dos moderadores da lista de discussão na internet $\mathrm{VJBR}{ }^{40}$ e também um dos produtores da primeira coletânea de VJ $\mathrm{S}$ lançada em DVD. Adepto do software livre, escolheu o VJing como tema para seu trabalho de conclusão da graduação ${ }^{41}$, com apresentação do projeto prático "Imagem Rara", uma performance de VJing com projeção de grafismos e imagens tridimensionais a partir de músicas da banda Teatro Mágico, que incorpora circo, teatro e poesias em seus shows.

Mariana K e Milena Zafir formam a dupla mm não é confete, que atua desde 2003 em apresentações de VJing, web art e performances urbanas como a "Manifestese! Todo mundo artista" 42 - carrinho de camelô transformado em uma ilha audiovisual que percorre as ruas de São Paulo, transmitindo depoimentos das pessoas ao vivo para site na internet. Também são autoras da "Performance-VJ ingWireless", que será detalhada no capítulo 5: "O processo em si: a mixagem ao vivo".

37 O Motomix é um evento promovido pela Motorola. Na festa de encerramento, realizada em setembro no Espaço das Américas, em São Paulo, os VJs projetaram imagens para os shows dos artistas Superdiscount, The Youngsters, Alex Kid e MC Solaar.

${ }^{38}$ A apresentação ocorreu em dezembro de 2005, no Espaço M, em São Paulo.

${ }^{39}$ No TIM Festival, realizado em outubro de 2005, no MAM, Rio de J aneiro, se apresentou como VJ ao lado de Spetto, Bijari, Akira e Nirvana.

40 O fórum de discussão VJ BR foi criado em 2003 pelo VJ pixel e entre seus membros estão VJ S, acadêmicos e curiosos.

41"O Visual Jockey e o hacking do vídeo", sob orientação do Prof. Dr. Almir Antônio Rosa, foi realizado como conclusão do Curso Superior do Audiovisual - ECA - USP.

${ }^{42}$ www. manifesto21. com. br, acessado em 20.01. 2008. 


\section{Antecedentes da projeção e manipulação de imagens ao vivo}

Ao recorrermos à história da animação, do cinema, da videoarte e da arte em geral, observamos que diversas criações e técnicas podem ser relacionadas à atividade de $\mathrm{VJ}$ ing.

0 processo de seleção de determinadas imagens por meio do teclado do computador - como faz o VJ Spetto com seu programa VRStudio -, ou utilizando-se um teclado musical via protocolo MIDI, bastante usado nas apresentações, assemelha-se aos experimentos realizados em 1743 pelo jesuíta e matemático francês Louis-Bertrand Castel, responsável pelo projeto do primeiro instrumento que possibilitava "tocar cores", um protótipo do que mais tarde viria a se tornar 0 color organ (PEACOCK, 1988:399). Com ele, som e imagem poderiam ser produzidos simultaneamente, através da associação das cores às notas musicais. Ou às invenções de Thomas Wilfred, que em 1922, inova criando o Clavilux, composto por seis projetores regulados por um teclado conectado a um banco de slides. 0 instrumento projetava elementos gráficos em uma tela, enquanto 0 performer controlava a intensidade das cores. Os trabalhos de Wilfred e seu Clavilux eram tão extraordinários, que os críticos da época comparavam suas proj eções à Aurora Boreal (PEACOCK, 1988:403). É interessante mencionar aqui a performance realizada em 1996 por Toshio Iwai e Ryuichi Sakamoto, "Music Plays Images x Images Play Music" ${ }^{43}$. No concerto multimídia transmitido em tempo real via internet, enquanto Sakamoto tocava um dos dois pianos presentes no palco, as notas da peça musical eram representadas visualmente por luzes em um grande telão semi-transparente. Quando essas luzes caíam sobre o segundo piano, este começava a tocar. Apesar de toda tecnologia envolvida, as imagens são semelhantes às obtidas pelo Clavilux de Wilfred.

\footnotetext{
${ }^{43}$ A performance foi realizada na Art Tower Mito, na cidade de Mito, J apão em 16 de dezembro de 1996. Mais informações no site:

www. aec. at/ en/ archives/ prix_archive/ prix_proj ekt. asp?iProj ectID=2494, acessado em 20.jan. 2008.
} 


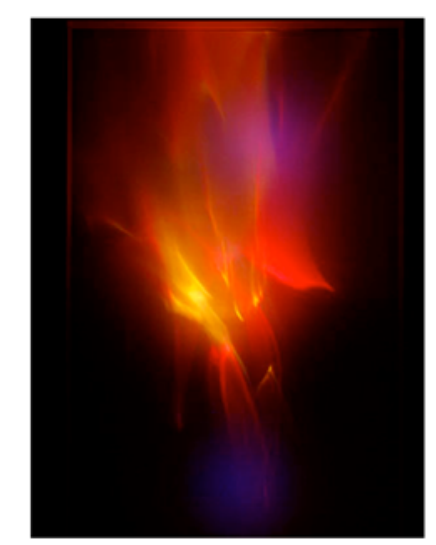

Figura 13 - Clavilux - Thomas Wilfred, 1922
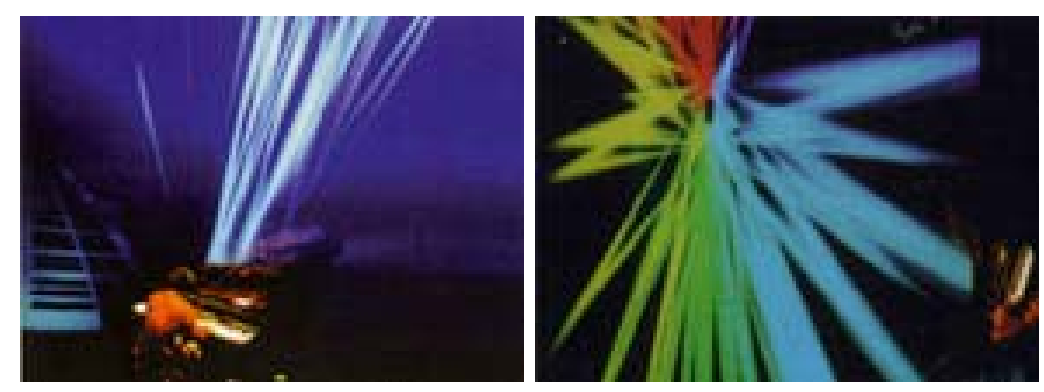

Figura 14 - "Music Plays Images x Images Play Music" - Toshio Iwai e Ryuichi Sakamoto, 1966

É difícil imaginar o surgimento do vídeo ao vivo sem as inúmeras criações existentes na história da animação, desde a invenção da lanterna mágica por Athanasius Kircher, em 1645, que possibilitava a projeção de slides pintados em lâminas de vidro, passando pelo praxinoscópio de Emile Reynaud, em 1877, e tantas outros experimentos que foram aperfeiçoando a técnica da projeção. Mas no século XX, há dois artistas extremamente importantes que são comumente citados como influência e parte da história do VJing: Oskar Fischinger e Norman McLaren. Nos anos 30, o alemão Fischinger, além de ter inventado o seu color organ, o Lumigraph, criou diversas técnicas. Conforme assinala Alberto Lucena, "ele não apenas expandiu o universo estético da animação abstrata como contribuiu com uma série de dispositivos e engenhosas inovações técnicas, como 0 método para criação sintética de som no filme"(LUCENA, 2002:86). Como 
exemplo, ele confeccionou uma máquina que efetuava cortes de fatias finas de blocos de cera, revelando formas inusitadas. Depois de fotografadas frame a frame, as imagens apresentavam abstrações em movimento. Essas configurações adaptadas à música atingiram extrema sincronia entre som e imagem. Fischinger ainda colaborou com Disney na produção do longa-metragem "Fantasia", de 1940, um marco na história da animação e exemplo de obra que privilegia a simultaneidade entre imagem e música. 0 pintor e animador britânico Norman McLaren, assim como Fischinger, utilizava o método direto na película. Como conta Lucena, "na ânsia pelo controle do tempo e do movimento, McLaren também se decidiu por desenhar o som. A animação sintética do som foi especialmente desenvolvida para a criação original de trilhas sonoras, em perfeita sincronia com o movimento e as características visuais dos desenhos" (LUCENA, 2002:94). As animações de McLaren poderiam perfeitamente serem projetadas numa pista de dança.

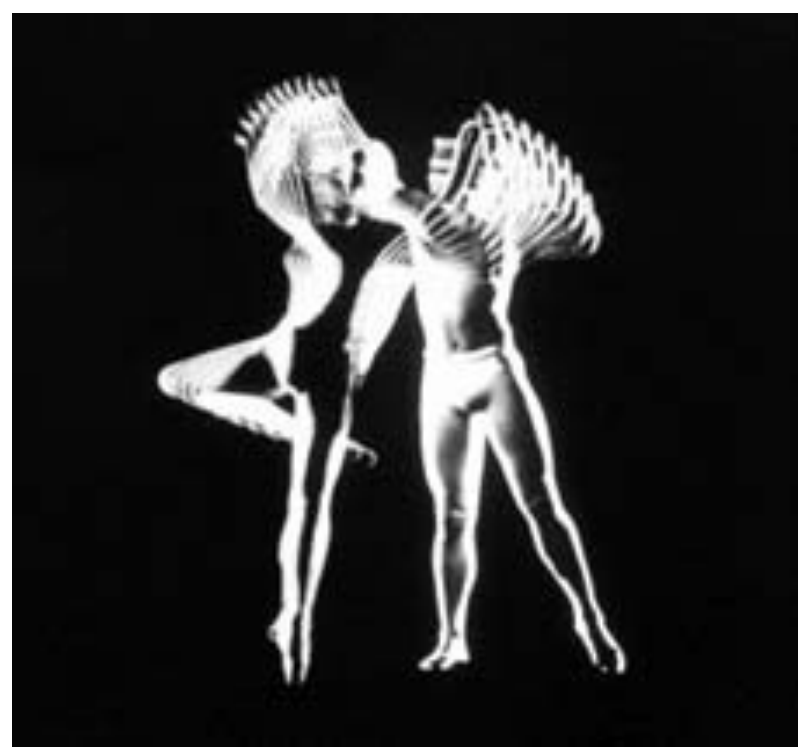

Figura 15 - "Pas de deux", de Norman McLaren.

Podemos também relacionar as performances de VJs com o início do cinema, quando os filmes eram exibidos em feiras, circos, teatros de ilusionismos, parques de diversões, cafés e vaudeviles - espaços originários do teatro de variedades e 
que em 1896 eram a forma mais freqüente de diversão popular (COSTA, 2005:40). Conforme aponta Mello, "nesse período o filme era uma entre outras várias razões que faziam com que as pessoas compartilhassem esses ambientes de convivência tão popular nos grandes centros urbanos" e conclui que "encontramos, de certo modo, a realidade desse cinema do início do século 20 reconfigurada nos ambientes das pistas de dança e nos modelos de apresentação dos DJ S e dos VJ s" (MELLO in http://p.php.uol.com.br/tropico/html/textos/1645,1.shl). Moran também foi buscar no cinema associações para discorrer sobre o VJing, mas recorreu à montagem de Eisenstein, para ela um processo tanto de construção de significados e conceitos quanto de afetação da percepção do espectador: "os princípios e métodos de Eisenstein falam de um tipo de espaço e fruição que se nos anos 20 e 60 eram desenvolvidos principalmente pelas vanguardas, hoje estão nas ruas, fazem parte da noite, são produto de consumo pop" (MORAN, 2004:15).

Movimentos surgidos ao longo da história da arte foram essenciais para a arte contemporânea e a eclosão do vídeo ao vivo. Podemos citar vários exemplos: as Seratas do Movimento Futurista na década de 1910, que reunia artistas de diversas vertentes para a leitura de manifestos, recitais poéticos, música e pintura; as obras de Duchamp e o movimento dadaísta, que defendia a combinação de elementos ao acaso; as colagens de imagens da action painting exercida por Pollock nos anos quarenta ou as assemblages de Kurt Schwitters, com a incorporação de diversos materiais à pintura. Essas contribuições culminaram, nos anos sessenta, na arte de performance, que buscava "uma vasta abertura entre todas as formas de expressão artística, diminuindo de um lado a distância entre vida e arte, e, por outro lado, que os artistas se convertessem em mediadores de um processo social" (GLUSBERG, 1987:12). Renato Cohen contrapõe a idéia de interdisciplina proposta na teoria de Gesamtkunstwerk ${ }^{44}$ de Wagner, onde a música se integra com a dança, o cenário e a iluminação de forma harmônica e linear, à interdisciplina presente na performance, onde a composição das linguagens ocorre por justaposição, colagem (COHEN, 1989:50). Segundo Cohen, a livre-associação e

\footnotetext{
${ }^{44}$ Termo alemão que significa "obra de arte completa", atribuído ao compositor Richard Wagner.
} Refere-se a uma apresentação de ópera que conjuga música, teatro, canto, dança e artes plásticas. 
a collage ${ }^{45}$ estão presentes na estrutura da performance, tanto no processo de criação, quanto na elaboração final (1989:61). Essas características também foram incorporadas na arte de VJing: a livre-associação e a justaposição estão presentes em todo o processo criativo, assim como a linguagem multidisciplinar, a mistura entre a arte e a vida e as colagens de imagens, potencializadas atualmente pelos recursos digitais para captação, tratamento, edição e manipulação dessas imagens.

Em seu livro Expanded Cinema, Gene Youngblood descreve diversos eventos intermidiáticos que faziam uso dos recursos tecnológicos da época, como o Kinetic Theatre, de Carolee Schneemann - que privilegiava a experiência sensória em suas proj eções - e os concertos experimentais de J ohn Cage. Em 1958, J ordon Belson se uniu ao compositor Henry J acobs e juntos eles realizaram os Vortex Concerts, onde abstrações visuais eram projetadas na cúpula do Morrison Planetarium, em São Francisco, ao som de música eletrônica (YOUNGBLOOD, 1970:388). Se estes concertos fossem realizados nos dias de hoje, Belson e Jacobs não poderiam ser considerados VJ s?

Na mesma década, nascem as experiências da videoarte, que surgiu a partir de tentativas de subversão do uso da TV e através da incorporação do improviso, outra importante característica do VJing, a ser analisada posteriormente. Temos então as contribuições de Nam J une Paik e suas transmissões ao vivo, como "Good Morning, Mr. Orwell", ligando três países em um programa via satélite na virada do ano de 1984 ou "Wrap Around the World", realizada em 1988 durante as Olimpíadas de Seul, quando imagens de várias partes do mundo foram mixadas e retransmitidas via satélite em tempo real. Machado ressalta que "a matriz dos clipes dançantes está nos vídeos musicais que Paik fez nos anos 70", como a coletânea "Global Groove", de 1973 (MACHADO, 2000:179), que “mixa" imagens de dança, comerciais, performance da violoncelista Charlotte Moorman, entre outras.

45 "Collage caracteriza a linguagem e a colagem em si é apenas uma das partes do processo de criação que inclui a seleção, a picagem e a montagem de imagens encontradas, ao acaso, de diversas fontes." (COHEN, 1989:60). 
Paik cria ainda, juntamente com o engenheiro eletrônico Shuya Abe, o sintetizador de imagens, segundo Machado:

capaz não apenas de distorcer a figura renascentista construída pela câmera, mas também de gerar imagens inéditas, sem necessidade de recorrer ao trabalho de enunciação da velha câmera obscura. Um dispositivo de teclados e botões favorece a modulação dos sinais de luminância, cor e saturação, de modo a permitir a um "intérprete" criar na tela do monitor paisagens abstratas em mutação constante, semelhantes às paisagens sonoras que se obtêm num sintetizador de música eletrônica (MACHADO, 1988:119).

A partir das criações de Paik, as imagens puderam ser "tocadas", distorcidas, misturadas, colorizadas, multiplicadas e manipuladas.

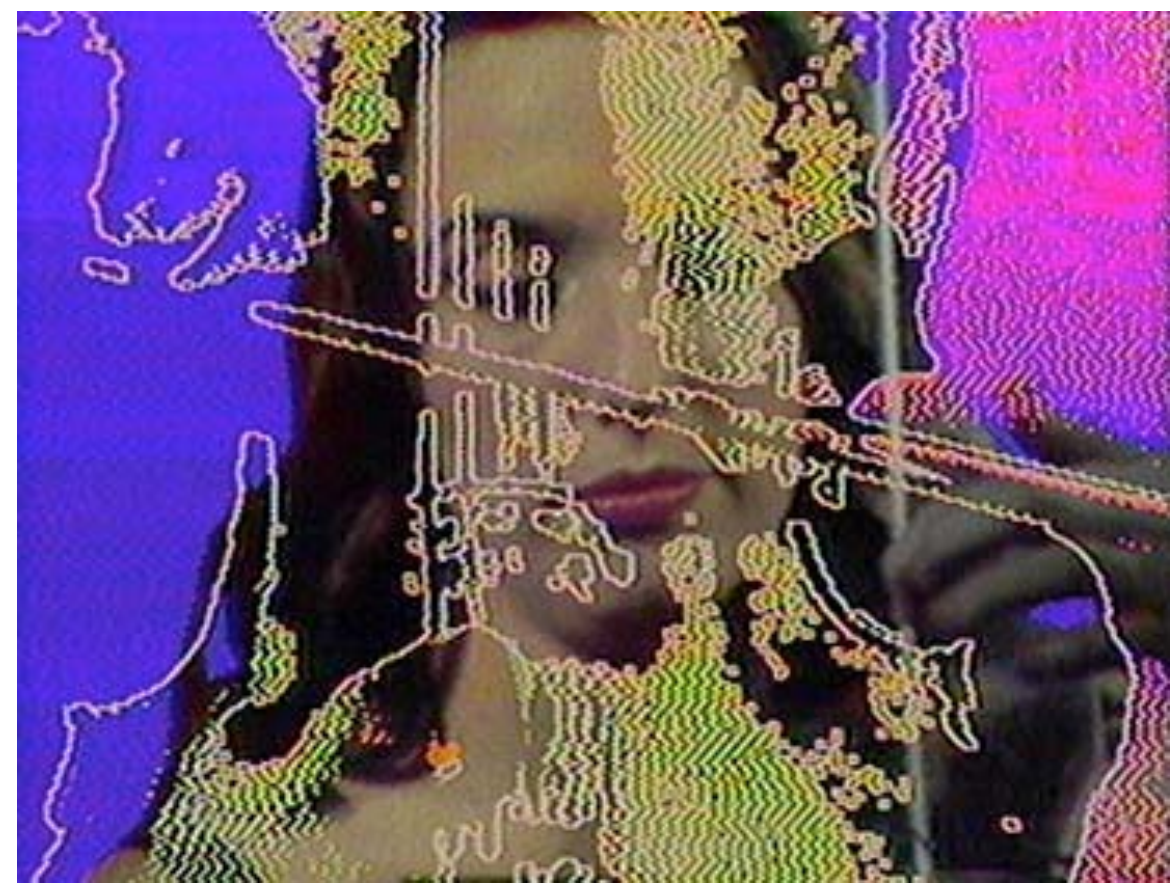

Figura 16 - "Global Groove”, Nam J une Paik, 1973. 


\section{Sob a ótica da visualidade}

\section{1 Imagens híbridas, fragmentadas, sobrepostas}

As imagens projetadas pelos VJs são resultantes do uso da tecnologia, que possibilita, através da digitalização, o intercâmbio entre artes diversas como 0 vídeo, a música, a fotografia, as artes plásticas e a utilização, pelo artista, de incontáveis referências fragmentadas, que após recombinadas, adquirem outro significado. Como salienta Couchot, "a ordem numérica torna possível uma hibridação quase orgânica das formas visuais e sonoras, do texto e da imagem, das artes, das linguagens, dos saberes instrumentais e dos modos de pensamento e percepção" (COUCHOT, 1988:47).

A hibridização é uma constante na arte de VJing. Fotos, trechos de filmes, imagens baixadas da rede, capturadas por câmeras de vídeo, criadas em programas de design gráfico, desenhadas à mão e escaneadas ou até mesmo captadas durante a apresentação - imagens do público dançando, por exemplo -, são utilizadas pelos VJs. Essas imagens situam-se no que Raymond Bellour conceitua como "EntreImagens", espaço de todas as passagens, "um lugar, físico e mental, múltiplo" onde "foto, cinema e vídeo se encontram e se misturam em uma multiplicidade de sobreposições e configurações pouco previsíveis" (BELLOUR, 1997:14). O resultado dessa mistura ao vivo dependerá do trabalho de pré-produção realizado pelo VJ e sua habilidade para selecionar e mixar imagens, além de fatores externos como a qualidade do projetor, tamanho e quantidade de suportes para projeções - telões, plasmas, videowall -, iluminação e a disposição da bancada onde situa-se o VJ, com bom ângulo de visão do telão ou monitores à disposição para acompanhar as imagens projetadas.

Mas se por um lado a tecnologia potencializa possibilidades, de outro pode causar uma pasteurização das obras produzidas, caso o VJ se limite a ser mero operador de softwares. O excesso de uso de efeitos disponíveis nos programas para VJing, por exemplo, contribui para essa pausterização, já que são facilmente 
indentificáveis por conhecedores dos programas. Couchot afirma que "o principal desafio do artista é mudar a destinação originária desses modelos que são concebidos para produzir conhecimento e não arte, ir além de sua acumulação tecnológica, interpretá-los e traduzi-los para o seu próprio sistema simbólico" (COUCHOT, 1988:46).

Assim, mesmo levando-se em conta que atualmente há programas específicos para VJing, isto é, concebidos para produzir arte, é necessário que o artista não se restrinja aos recursos oferecidos, o que não significa que este precise ser um programador ou técnico, a ponto de branquear a "caixa preta" para ser "o verdadeiro sujeito da transformação criadora", como defendia Vilém Flusser (FLUSSER, 2002:15).

Isto também significa dizer que a intenção de se fazer arte, o conhecimento e background do artista, seu contexto cultural, olhar e posicionamento crítico, devem corroborar para uma estética peculiar e um viés poético diferenciado entre os procedimentos e resultados apresentados pelos diferentes profissionais desta área.

Durante a pesquisa realizada para esta dissertação, observou-se que os VJ s que possuem trabalhos relevantes vão além da manipulação de programas. São artistas multimídia, interdisciplinares, conhecedores de equipamentos, programas de tratamento e edição, pesquisadores de novas formas de projeção e com sensibilidade para interpretar as manifestações do público presente, selecionar as imagens mais adequadas no momento e mixá-las com maestria.

\section{2 Imagens recicladas, recombinadas}

A autoria das imagens utilizadas no VJing é outro ponto interessante a se observar. Muitas delas são trechos de filmes, vídeos, programas de TV, fotos baixadas da internet, em um processo semelhante ao que acontece na cena musical eletrônica, 
onde trechos de músicas são sampleados para comporem uma nova mistura. Mas o procedimento não é exclusivo da arte de VJing. Pierre Lévy constata nas artes virtuais o "declínio das duas figuras que até agora garantiram a integridade, a substancialidade e a totalidade possível das obras: o autor e o registro" (LÉVY, 1997:95). O descaso com os direitos autorais é comum no meio. De acordo com o coletivo de artistas Critical Art Ensemble ${ }^{46}$, “hoje se pode argumentar que o plágio é aceitável, até mesmo inevitável, dada a natureza da existência pós-moderna com sua tecno-infra-estrutura" (2001:85). E enfatiza: "um dos principais objetivos do plagiador é restaurar o fluxo dinâmico e instável do significado, apropriando-se de fragmentos da cultura e os recombinando". Muitos VJ S inclusive disponibilizam seus acervos de imagens para outros usarem. Um bom exemplo dessa cultura de reapropriação é o trabalho do Coletivo Virtual, idealizado pela VJ Bete Rum. Qualquer pessoa pode acessar o site do Coletivo e "postar" seu loop de vídeo, que automaticamente fica disponível para uso dos visitantes. As apresentações do Coletivo são realizadas por colaboradores do site, que mixam todo esse conteúdo ao vivo, "costurando uma colcha de retalhos". Segundo a VJ, o objetivo é fomentar um processo contínuo de criação e recriação onde todos possam ser "artesãos digitais". Após tratamento e manipulação das imagens, estas são inseridas em um novo contexto e adquirem outros significados. Essa recombinação é a essência do trabalho de VJing.

\footnotetext{
${ }^{46}$ O Critical Art Ensemble é um coletivo de cinco ativistas, focado na exploração das intersecções
} entre arte, teoria crítica, tecnologia e política radical. 


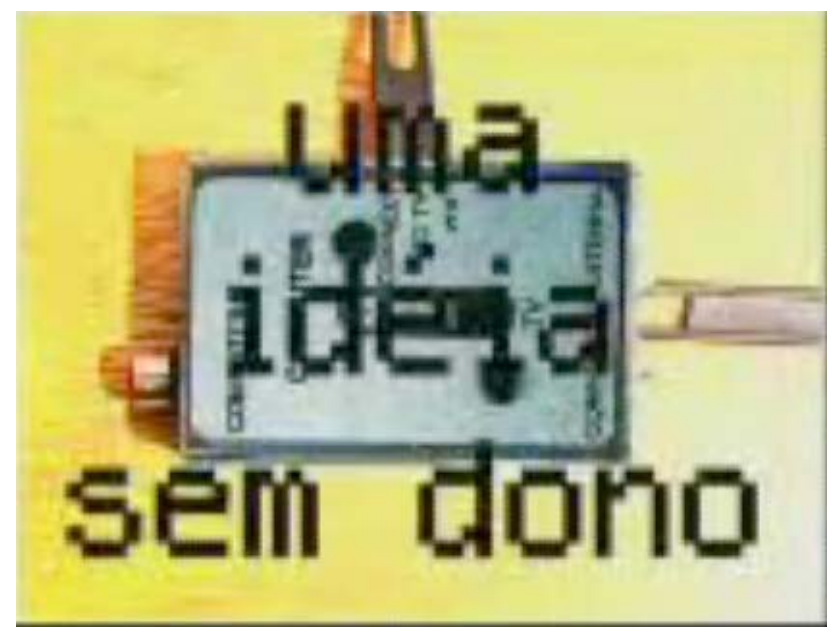

Figura 17 - "Uma idéia sem dono. Um coletivo sem estrela", projeção do Coletivo Virtual.

\subsection{A não-linearidade}

Na projeção e manipulação de imagens ao vivo na cena da música eletrônica de pista - casas noturnas, festivais e raves -, há dispersão do público. O VJ não é a atração principal do evento, que tem como finalidade, o entretenimento. As pessoas vão para conferir o DJ ou banda, beber, dançar, paquerar. Como observa Moran, "as imagens acontecem entre um diálogo e outro, entre um gole e outro, entre um beijo e outro" (MORAN, 2004:20). A música alta, o ambiente escuro, a iluminação, o deslocamento do público, tudo isso em conjunto com as imagens, estimulam os sentidos. Machado observa a ausência de uma narrativa linear, já que "em locais onde o público predominantemente vai para dançar, não faz sentido imagens que exigem acompanhamento, contemplação, atenção fixa na tela". Os "videoclipes endereçados aos clubbers", como ele denomina, apresentam "padrões de estimulação retiniana muito semel hantes aos padrões rítmicos da música, o que as aproxima fortemente daquela iconografia pulsante que Nam June Paik transformou em arte e expressão de uma sensibilidade contemporânea" (MACHADO, 2000:179). 
Muitas projeções são compostas por imagens sem relações umas com as outras, onde um trecho de vídeo se transforma em uma animação, que muda para um grafismo e assim por diante. Ou ainda são constituídas somente por imagens abstratas, como no caso dos sets do VJ 1mpar. Esse fenômeno é característico da arte tecnológica, onde "transita-se por uma lógica do provável, através de lógicas não-lineares, estruturadas nas permutações disponíveis do mosaico eletrônico" (DOMINGUES, 1993: 104).

A ausência de narrativa linear, porém, não implica que as imagens escolhidas no momento da apresentação sejam sempre desconexas. Mesmo fragmentadas, recortadas, distorcidas, as imagens em sequência - misturadas às palavras ou não podem promover associações, provocar insights, transmitir mensagens. Como exemplo, podemos analisar um trecho de uma projeção realizada pelo VJ Kiko Ferraroni $^{47}$ durante apresentação na casa noturna Clash. Em determinado momento, é exibida a imagem de um toca-discos com um disco de vinil girando. Um zoom aproxima a imagem e vemos o vinil como um globo terrestre. A aproximação continua e mostra o buraquinho no meio do disco. Como se olhássemos através dele, uma outra imagem surge e vemos um homem segurando um vinil no alto de sua cabeça, no qual se lê a palavra "FREE". Podemos interpretar essa seqüência de diversas formas: uma exaltação ao vinil, objeto de trabalho do DJ que comanda a pista e à música de modo mais amplo, um protesto à supertaxação do disco de vinil importado, excessivamente tributado e que prejudica DJ s, produtores e músicos, ou ainda uma alusão à liberdade de utilização de trechos de músicas - samplers -, sem o pagamento de direitos autorais. Mello compara a montagem dos filmes de Eisenstein e o cinema de associação de Vertov ao vídeo ao vivo, onde há "a necessidade de elaboração de um processo de analogia entre uma e outra imagem, deixando a cargo do público a construção final dos sentidos do trabalho" (MELLO, 2004:64).

\footnotetext{
${ }^{47}$ As imagens citadas foram projetadas na casa noturna Clash Club, São Paulo, em 03 de junho de
} 2007. 
No 160 Festival Internacional de Arte Eletrônica SESC_Videobrasil, o cineasta britânico Peter Greenway apresentou a "Tulse Luper Live Performance" ${ }^{48}$, um trabalho de live images exibido ao ar livre, projetado simultaneamente em três telões e na parede de um edifício. Ao anunciar sua obra, Greenway decretou a morte do cinema convencional e declarou-se favorável à ausência de narrativa, um "cinema de imagens" no lugar de um "cinema de palavras". Através de uma interface touch screen, Greenway acionava seu banco de imagens composto por fragmentos de filmes sobre a vida de Tulse Luper. As belas imagens eram então cortadas, fundidas e sobrepostas ao vivo, sem muitos efeitos, manipuladas mais como se utilizasse uma mesa de edição, do que um software para VJ ing. Em alguns momentos a mesma imagem ocupava os três telões, em outros elas entravam em tempos diferentes: primeiramente no segundo telão, depois no primeiro e em seguida no terceiro, provocando uma sequência em loop. Apesar de não existir narrativa linear, a projeção obedecia uma lógica: o conteúdo das noventa e duas maletas de Luper. Ao estabelecer uma comparação com os filmes, Gabriel Menotti observa que ao libertar a vida de Tulse Luper da linearidade do cinema, Greenway "ofusca sua personagem" e, ao recriar o espaço onde acontece a projeção, faz com que "a imagem seja renegada à condição de cenário" (MENOTTI, 2007:75). Durante a apresentação, trechos dos filmes eram exibidos com áudios dos mesmos, enquanto um DJ comandava a música, sem sincronia com as imagens. A música parecia mais ter o intuito de "criar um clima" para a projeção do que fazer as pessoas dançarem. O cineasta, pouco atento às reações do público, tinha o ol har direcionado aos telões, discordando portanto de Menotti quando este descreve que Greenway "define os rumos da apresentação sob o escrutínio constante da audiência" (2005: 73).

\footnotetext{
${ }^{48}$ A apresentação, definida como uma performance de VJing pelo grupo que promove a turnê www. notv.com - foi realizada na área externa do Sesc Avenida Paulista, em 30 de setembro de 2007. A estréia da Tulse Luper Live Performance foi em 17 de junho de 2005, nos 12 telões do Club 11, em Amsterdã e a noite também contou com a apresentação do VJ Spetto. O filme "The Tulse Luper Suitcases", de Greenway, reconstitui a trajetória do escritor galês Tulse Luper através de noventa e duas maletas encontradas ao redor do mundo.
} 


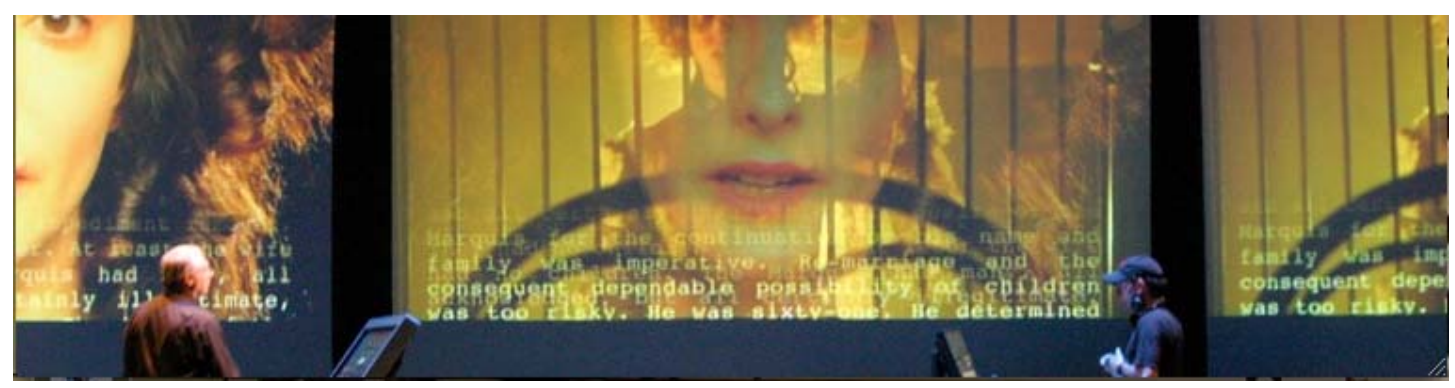

Figura 18 - "Tulse Luper Live Performance", realizada no 160 Videobrasil, São Paulo.

Percebe-se que o impacto no público poder ter sido diferente no caso de pessoas que tiveram ou não algum contato com o projeto "The Tulse Luper Suitcases", composto por filmes, livros, programas de TV, DVDs, websites e exposição com o conteúdo das noventa e duas maletas de Luper realizada nas dependências do Sesc. Como afirma Menotti, "o foco do projeto não se revela em cada um desses obj etos, e sim como organização que Ihes dá coerência, na relação que estabelece entre as mídias às quais eles se integram" (MENOTTI, 2007:69). Para o primeiro grupo, as referências colaborariam para uma maior compreensão do trabalho. Estabelecendo uma comparação com o set audiovisual da dupla inglesa Addictive TV, já mencionado nesta dissertação, seria a mesma situação caso algumas pessoas presentes não tivessem assistido ao filme "Cidade de Deus", o que seria pouco provável. Mas a absoluta sincronia entre som e imagem e o ritmo da projeção, neste caso, causavam maior dinamismo. Greenway propõe um cinema para outros tipos de ambiente, ao ar livre ou em casas noturnas, feito para as pessoas dançarem. Paradoxalmente, a performance vista no Videobrasil pareceu mais apropriada à tradicional sala de cinema, diferentemente da apresentação dos VJ S do Addictive TV. 


\subsection{Além das pistas}

As performances em cinemas, teatros e galerias exigem outro tipo de contemplação, já que diferentemente do que ocorre na cena musical, a atenção do público está voltada para a tela. O coletivo Laborg possui trabalhos audiovisuais para serem exibidos exclusivamente em teatros ou cinemas, como o "Fluxo 04" 49. Com o público sentado, eles acreditam que este possa usufruir uma experiência imersiva mais intensa.

O ON_OFF - Experiências em Live Image, ${ }^{50}$ tem como objetivo exibir criações de artistas que se utilizam de diversos meios e linguagens para compor e mixar imagens. Na 3a edição do evento o VJ Alexis apresentou, juntamente com o DJ Gen, uma performance audiovisual denominada "Repentismo Visual", na qual um vídeo de sua autoria, intitulado "Christiane F, Drogada e Publicitária", era mixado com campanhas anti-drogas veiculadas na TV, além de trechos de filmes, programas, documentários e videoclipes. As imagens eram exibidas no telão principal e em duas TVs de plasma situadas em frente ao público. De tempos em tempos, essas imagens eram deslocadas para as paredes laterais do teatro com a utilização de um projetor móvel. Alexis acredita que o conteúdo exibido neste tipo de apresentação é totalmente diferente dos utilizados nas pistas de dança e shows, onde algumas regras precisam ser seguidas, como não utilizar imagens claras, sincronizá-las com a música, entre outras.

Já Luiz Duva costuma levar obras suas exibidas nos circuitos artísticos para as pistas, manipulando-as de maneira diferente. Um exemplo foi a projeção de "Vermelho Sangue", já mencionado anteriormente, durante o show do DJ inglês Fatboy Slim ${ }^{51}$. Ao invés de um pequeno grupo, o público era composto por uma platéia de milhares de pessoas. No lugar do teatro ou galeria, a Praia do Flamengo. A música experimental de Wilson Sukorski foi substituída pela eletrônica do DJ.

\footnotetext{
${ }^{49}$ Vídeo disponível no www. youtube.com/watch?v=DDK7UQSkVYQ, acessado em 11 de dezembro de 2007.

${ }^{50}$ A 3ạ edição do ON_OFF, realizada no Itaú Cultural, aconteceu de 26 a 29 de setembro de 2007.

${ }^{51} \mathrm{O}$ DJ Fatboy Slim se apresentou no Nokia Trends, na Praia do Flamengo, Rio de J aneiro, em 07 de fevereiro de 2004.
} 
Como observa Moran, a música de Fatboy e a praia solicitaram de Duva uma manipulação menos detalhista, com duração menor das imagens (MORAN, 2004:11).

\subsection{Inovações nas projeções ao vivo}

Novos formatos e suportes para a projeção e manipulação de imagens ao vivo têm surgido, apesar de que a maior parte dos eventos continuam presos ao modelo do cinema. Menotti observa que "a projeção concentrada em um ponto único do ambiente, provoca uma catástrofe gravitacional no espaço cognitivo. Seu enorme peso semântico curva o espaço em sua direção, atraindo corpos e atenções como um buraco negro" (MENOTTI in http:/ / netart. incubadora.fapesp. br/ portal/ Members/ menotti/ rants/ wetware/03_ cinema/ ?searchterm=None).

Em grandes festivais a disposição mais comumente encontrada é a de um telão central no palco e mais dois laterais, projeções nas paredes das tendas, painéis GLEC (confeccionados com lâmpadas LED) ou videowall. No show do DJ Erick Morillo, em Brasília ${ }^{52}$, o coletivo Desconstrução apresentou seu trabalho em quase 360 e de projeção em telões que contornavam a pista, contribuindo para uma experiência imersiva.

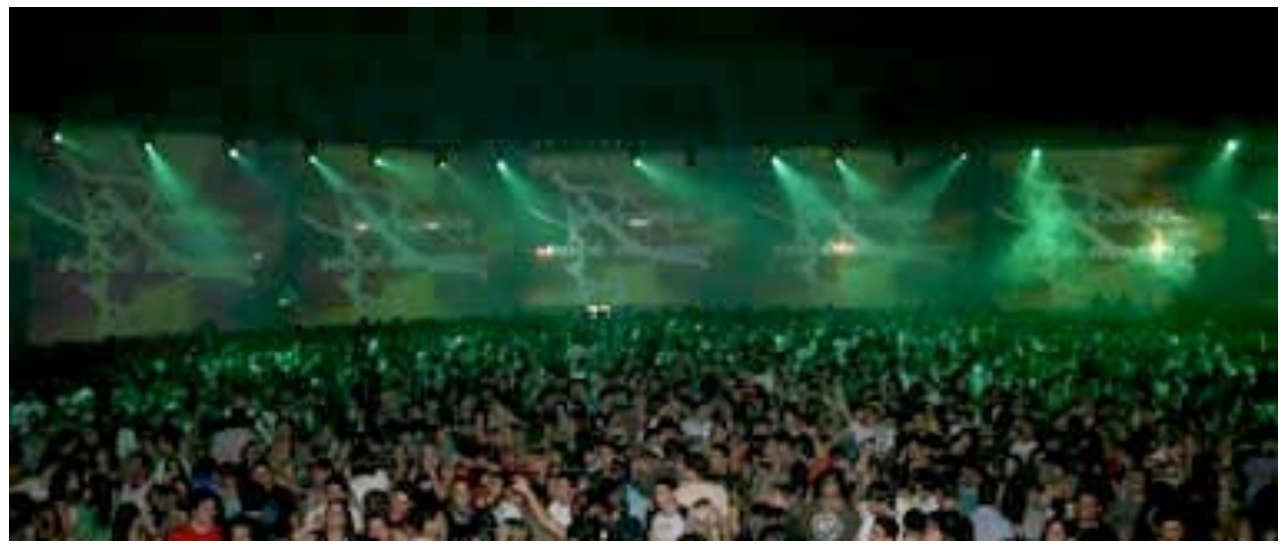

Figura 19 - Coletivo Desconstrução no show do DJ Erick Morillo, Brasília.

\footnotetext{
${ }^{52}$ Apresentação ocorrida em 27 de outubro de 2007 no Centro Ulysses Guimarães, Brasília.
} 
O VJ Alexis possui uma equipe de artistas, animadores, engenheiros de projeções e produtores, a Visual Farm, com o objetivo de pesquisar e desenvolver novos formatos de projeção, viabilizados através de trabalhos comerciais realizados para empresas. Ao invés de usar os telões, Alexis tem utilizado outros tipos de suportes: esculturas de tecido tensionadas, telas quase translúcidas que permitem um efeito holográfico na imagem projetada ou quadriláteros de telas com oito projetores (dois de cada lado) dispostos internamente, possibilitando a visualização das imagens tanto do lado de dentro, quanto do lado de fora da estrutura. Na exposição Ecos do Planeta ${ }^{53}$, sobre a Mata Atlântica, a projeção foi utilizada para criar um ambiente sensorial. Um projetor móvel fixado no centro de uma sala redonda girava, fazendo com que bichos "corressem" e "voassem" ao redor do público.

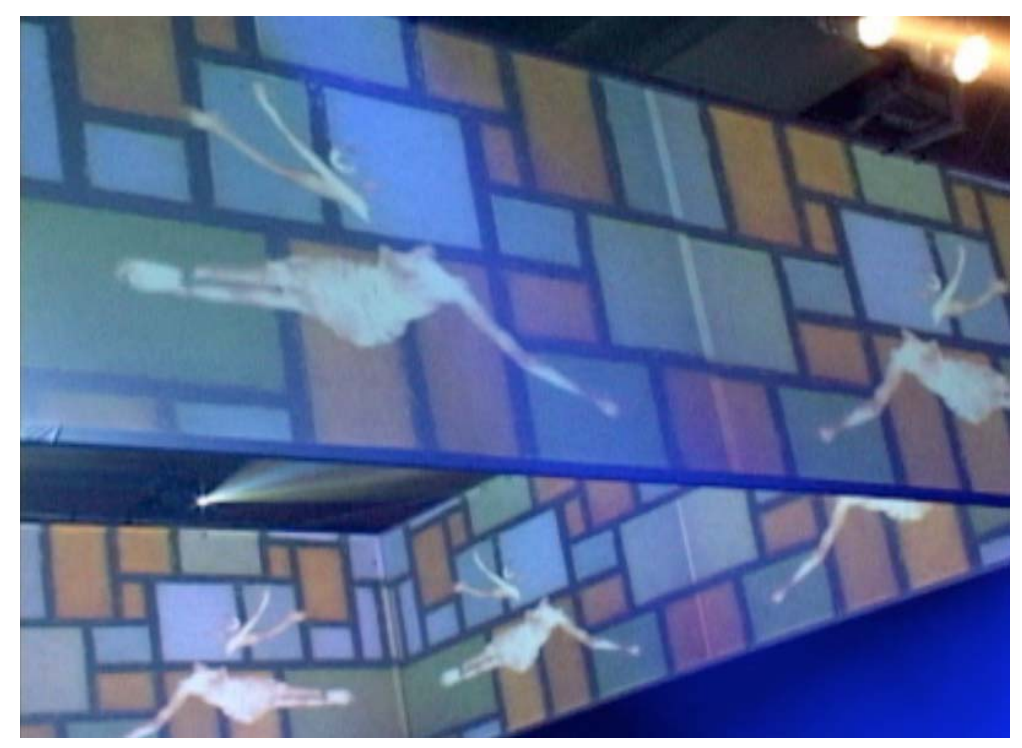

Figura 20 - Quadrilátero de projeção, da Visual Farm.

\footnotetext{
${ }^{53}$ A exposição Ecos do Planeta aconteceu no prédio da Bienal do Parque do Ibirapuera, em São Paulo, de 3 a 7 de outubro de 2007.
} 
Outro exemplo é a projeção realizada na Fonte do Pão de Açúcar ${ }^{54}$. Neste caso a água foi utilizada como suporte. Um projetor com lente muito potente situava-se a cerca de sessenta metros de distância da fonte, uma "tela" de dez metros de altura. Foram necessários muitos estudos e ensaios para realização do trabalho, pois a quantidade de água teve que ser regulada de modo que as imagens projetadas ficassem nítidas. Com o tema "A Água e a Natureza", a imagem de uma mulher emergia das águas e dançava ao som de clássicos da música, incluindo uma versão eletrônica de "Singing in the Rain". Os movimentos e a luz da bailarina, somados ao sons dos jatos de água e à música, resultaram em um espetáculo onírico.

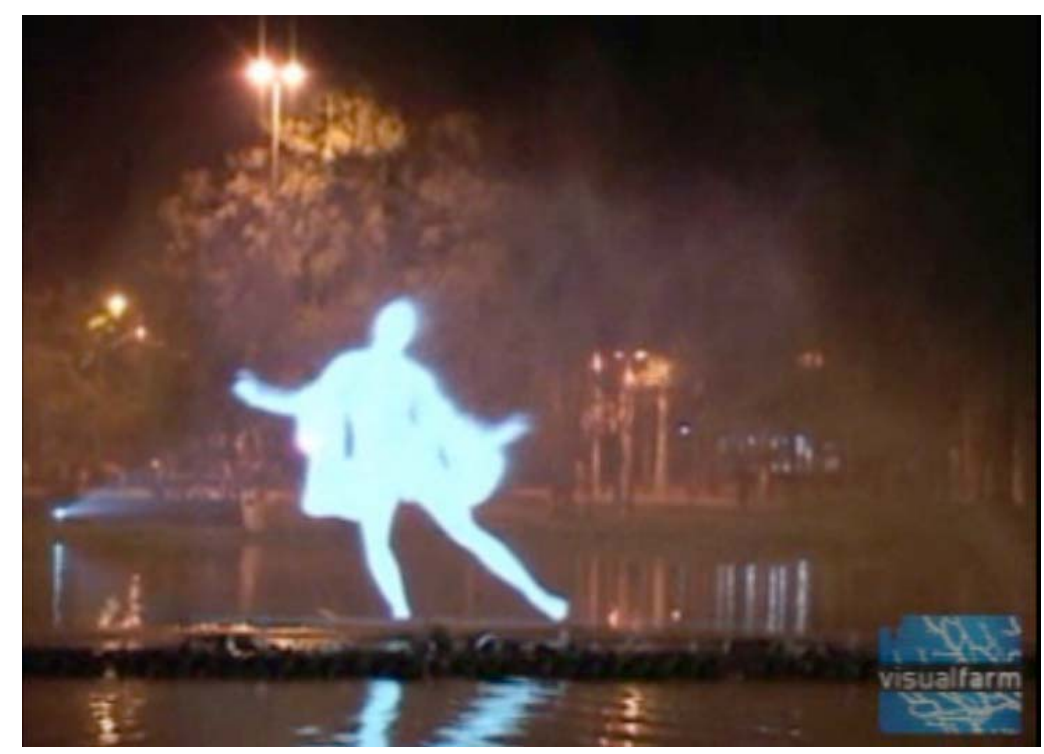

Figura 21 - VJ Alexis e Visual Farm, Fonte do Pão de Açúcar, Parque do Ibirapuera.

\footnotetext{
${ }^{54}$ Evento realizado no aniversário no Parque do Ibirapuera, entre os dias 5 e 27 de agosto de 2007, com proj eções de Alexis/ Visual Farm e trilha da Scratch Studios.
} 
O VJ Spetto se especializou em projeções multitelas de grandes formatos. Por conta disso, foi convocado para "embrulhar" o Royal Festival Hall ${ }^{55}$, em Londres, com projeções. Eram doze telas de doze por nove metros ao redor do edifício, onde foram projetadas imagens criadas especialmente para o evento por VJs e videoartistas, como Ryoichi Kurokawa, Summit Sankar e o coletivo Laborg, mixadas com material do acervo do British Film Institute. Em uma projeção comum, as telas mostrariam imagens repetidas. Com as multitelas, diversos projetores exibem a mesma imagem em grande escala - 1920x480 pixels por exemplo, três vezes a dimensão convencional -, pois cada um projeta uma parte da imagem. Spetto acredita que as luzes e projeções são capazes de transformar arquitetura do local: "o poder da luz transpondo a rigidez do concreto, aço, ferro, criando um ef eito Iúdico inesperado, feito ao vivo, multicolorido, em grande escala" 56.
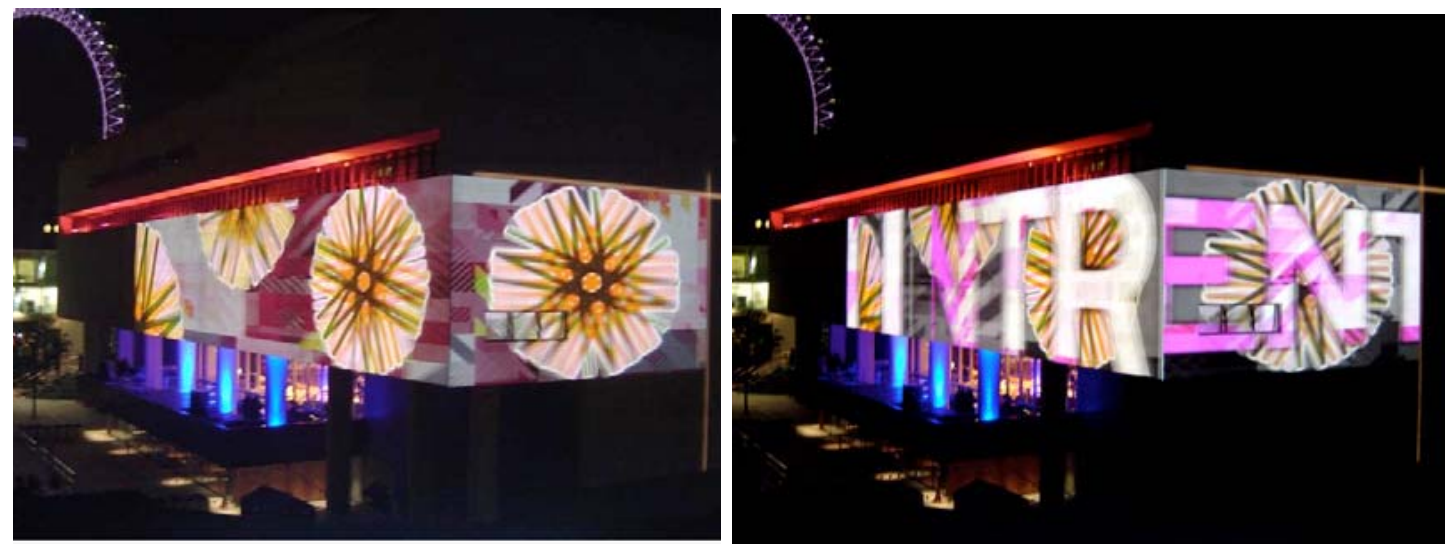

Figura 22 - Projeções multitelas do VJ Spetto no Royal Festival Hall, Londres.

\footnotetext{
${ }^{55}$ O evento no Royal Festival Hall fez parte das comemorações da chegada do verão londrino no Launch Events Southbank Centre 2007 e foi realizado nos dias 8 e 9 de junho, sob curadoria artística de Pedro Zaz.

${ }^{56}$ Fonte: http:// blog. visualradio.com. br/2007/ 06/ 15/ 33, acessado em 5 de dezembro de 2007.
} 


\section{A linguagem musical atuando no processo}

\subsection{A tecnologia viabilizadora das performances}

Os equipamentos básicos usados pelos VJ s assemelham-se em suas funções aos dos DJ S: dois laptops que armazenam as imagens e um mixer ${ }^{57}$. Podem ser utilizados também aparelhos como o DVJ, da Pioneer, que permite a manipulação de um DVD como se este fosse um disco de vinil, tornando possível a realização de scratches, por exemplo. 0 efeito do scratch foi anteriormente explorado nas imagens através da técnica do scratch video nos anos oitenta - a partir da gravação do zapping em alta velocidade em uma fita VHS e a manipulação dessas imagens em mesas de edição -, mas não o scratch no sentido original do termo, o movimento com a mão. É interessante observar que equipamentos digitais para manipulação de imagens sejam criados para simular efeitos analógicos pertencentes ao mundo musical. Segundo Bambozzi "esse fenômeno se caracteriza menos pelo desafio de se buscar novas linguagens a partir de novas tecnologias do que pelo emprego de novas técnicas para a reprodução de procedimentos analógicos, de um contexto prédigital $^{58 " ~(B A M B O Z Z I, ~ 2005: 5) . ~ E m ~ a p r e s e n t a c ̧ o ̃ e s ~ a u d i o v i s u a i s ~ p o d e ~ s e r ~ u s a d o ~ u m ~}$ mixer para áudio e vídeo como o Numark AVM02, que viabiliza transições ${ }^{59}$ de uma imagem para outra, de uma música para outra. Assim como na música tocada pelos DJ S, a mixagem é inerente ao VJing, pois permite combinações múltiplas definidas no calor das apresentações ao vivo.

\footnotetext{
${ }^{57}$ Para mixar as imagens são usadas mesas de edição de televisão, mixers específicos para VJ ing (mais recentes) ou o próprio software.

58 Aqui Bambozzi refere-se ao aparelho Final Scratch, da Stanton, que permite que músicas disponíveis em um computador sejam tocadas como se estivessem em um LP, através de vinis especiais que armazenam códigos e rodam no programa Linux.

${ }^{59}$ Essas transições recebem o nome de crossfades.
} 


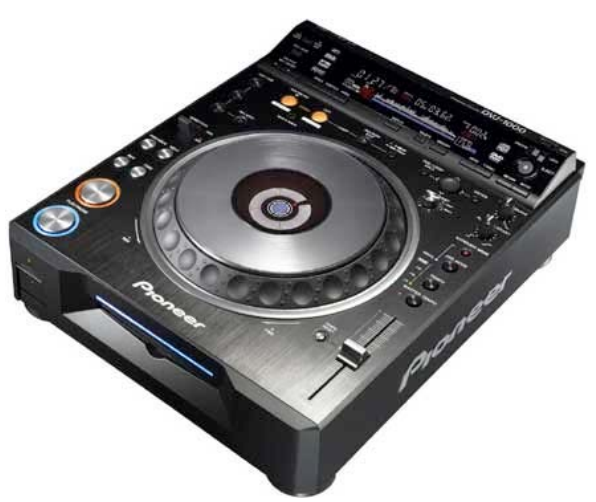

Figura 23 - DVJ -1000, da Pioneer.

A linguagem musical também está presente no uso do protocolo MIDI (Musical Instrument Digital Interface) em computadores conectados a instrumentos musicais, sendo mais comuns os teclados. Através da associação das teclas e botões ao software usado para a projeção, cria-se uma interface musical e pode-se "tocar" as imagens selecionadas, além de acionar mais de um efeito simultaneamente, o que não é possível através do teclado ou mouse do computador. O VJ Albuk, por exemplo, adaptou uma unidade de efeitos de guitarra, "composto por controles giratórios que permitem controlar as transparências das camadas de vídeo, parâmetros de efeitos, a velocidade dos loops e fazer scratch visual" (VIEIRA, 2007:19). Bambozzi enfatiza a importância da possibilidade de se "afastar do referencial do computador e do anacrônico teclado 'qwert', que pouco tem a ver com a música ou a imagem" (BAMBOZZI, 2005:6).

Os softwares para VJing, em suas lógicas e interfaces, são semelhantes aos usados em performances musicais, espetáculos de teatro ou dança. 0 Isadora ou 0 MAX/MPS, por exemplo, servem para ambos. VJ Albuk classifica os softwares em duas categorias principais: sintetizadores e samplers. Os primeiros geram imagens através de cálculos, onde a partir de um ponto inicial a imagem segue um fluxo: efeitos, mixagens, inputs externos, até o resultado final. São exemplos o VisualJ ockey, Isadora, VDMX e GePhex. Já os samplers operam em tempo real, 
disparando loops, sobrepondo camadas e gerando transparências entre os vídeos. Possibilitam também adicionar efeitos e capturar imagens de câmeras e sinais de vídeos externos. Resolume, Flowmotion, Modul8, Grid e VeeJ ay estão entre eles (VIEIRA, 2007:11-12). A declaração de Mark Coniglio, criador do Isadora, é uma evidência da busca pela linguagem musical. Ele afirma ter escrito o software não apenas como um programador, mas também como compositor, já que estudou com Morton Subotnick, um dos pioneiros da música eletrônica $(2005: 86){ }^{60}$.

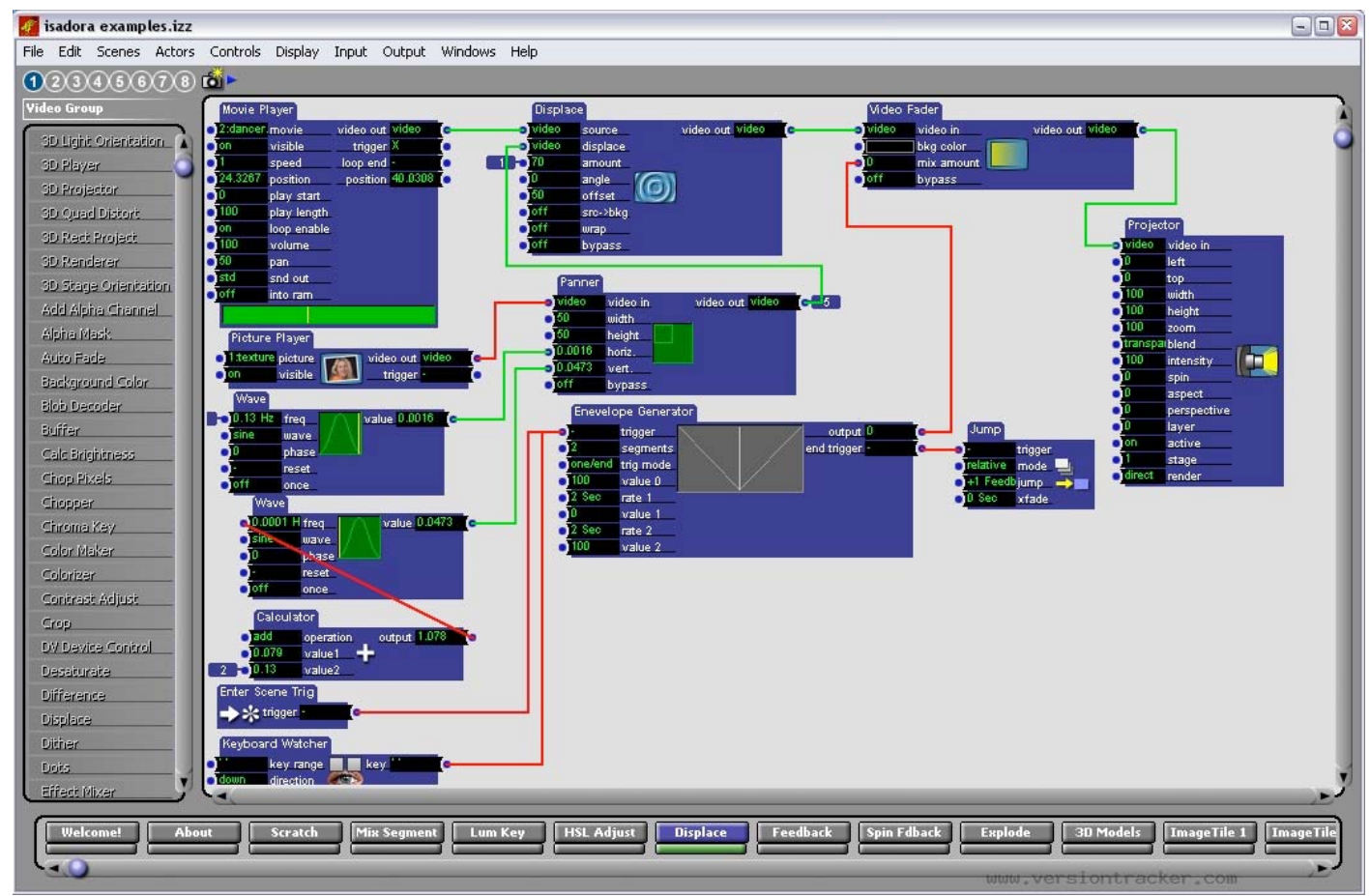

Figura 24 - Interface do programa Isadora.

${ }^{60}$ A declaração de Mark Coniglio foi concedida em entrevista para o livro The VJ Book, de Paul Spinrad. Informações completas na bibliografia. 


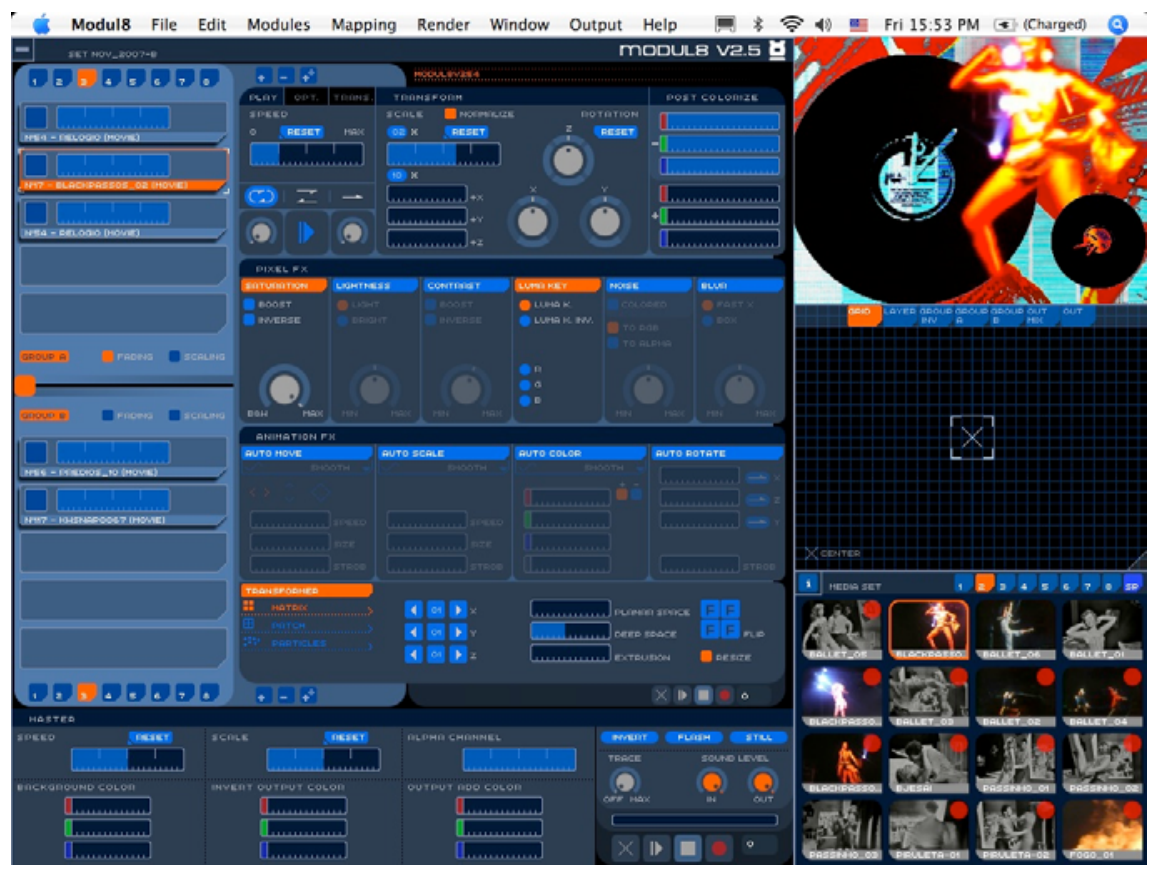

Figura 25 - Interface do programa Modulat8.

Assim como na cena musical contemporânea, a internet possui papel fundamental na formação e disseminação do VJing. Além do acervo de imagens disponíveis na rede, há softwares livres e fóruns de discussão, como o brasileiro VJ BR ${ }^{61}$ e 0 internacional VJ Central, com artigos, informações sobre equipamentos, calendário de eventos e vídeos cadastrados por VJ s de todo o mundo. Em artigo, Kim Cascone enfatiza o papel da internet na divulgação da música digital e no auto-didatismo de seus compositores, que a utiliza tanto como ferramenta de aprendizado, quanto como meio de distribuição de seus trabalhos, em um "loop de feedback cultural" ${ }^{62}$ (CASCONE, 2000:17). Segundo o autor, pela primeira vez na história a produção criativa está extremamente ligada à distribuição.

\footnotetext{
${ }^{62}$ "The artist completes a cultural feedback loop in the circuit of the Internet: artists download tools and information, develop ideas based on that information, create work reflecting those ideas with the appropriate tools, and then upload that work to a World Wide Web site where other artists can explore the ideas embedded in the work".
} 


\subsection{A recriação do espaço}

O VJ Spetto acredita que a proposta do VJing é criar outra ambiência, através da reconstrução do espaço onde acontece a apresentação ${ }^{63}$. Essa transformação do espaço também era ocasionada pela música concreta nos anos quarenta. Robin Minard ressalta a importância deste estilo musical para as artes visuais e a formulação de um conceito onde os sons, seus contextos espaciais e os elementos visuais tornam-se uma coisa só, criando um espaço multisensorial. Segundo o autor, as idéias do compositor Pierre Schaeffer "libertaram os sons de seus contextos originais e estabeleceram uma estrutura onde o som foi colocado à disposição do artista como um novo material, para ser trabalhado e moldado com todas as formas do processo criativo abstrato" (MINARD, 2002:48, traduzido). Simon Emmerson, por sua vez, enfatiza que a música eletroacústica alterou a relação ouvinte/ performer/compositor e contribuiu para a mudança dos espaços de realização de concertos, inadequados para as necessidades contemporâneas, pois "o ouvinte procura um espaço multimídia, que mistura música, imagens e socialização" (EMMERSON, 2001:19, traduzido). É exatamente esta relação que é encontrada nos clubes noturnos e eventos artísticos contemporâneos.

\subsection{0 jazz e o improviso durante as apresentações}

Além de visual jockey, em outros países o VJ também recebe o nome de visual jammer. Este nome estabelece um elo com a música e talvez seja até mais apropriado, já que assim como nas jam-sessions, o improviso move as performances de $\mathrm{VJ}$ ing. A comparação com 0 jazz torna-se portanto, inevitável e tem sido recorrente em artigos e trabalhos acadêmicos. Para estabelecer essa comparação, faz-se necessário o entendimento de como acontecem as improvisações neste tipo de música. Conforme explica André Francis, as

${ }^{63}$ Declaração para a matéria "Império dos Sentidos" - Revista Simples, no21, edição mai/ jun 2003. 
improvisações geralmente contam com tema e acompanhamento. Há improvisações coletivas e individuais. Nas coletivas, é possível improvisar a partir de qualquer tema e o improvisador costuma se apoiar sobre estruturas simples, de doze, dezesseis e trinta e dois compassos. Nas individuais pode-se parafrasear, quando se respeitam as linhas principais da curva melódica ou executar variações livres, quando se baseia sobre as harmonias do tema para criar uma nova linha melódica. Essas duas formas de improvisação podem vir interpenetradas. No free-jazz, os músicos improvisam sem qualquer base, o que faz com que o resultado seja totalmente imprevisível (FRANCIS, 1997: 275-276). Pode-se perceber que o risco faz parte das apresentações, mas este parece ser calculado, pois estruturalmente a peça se preserva coerente. Já a improvisação sem base alguma é arriscada.

Nas performances de VJing em clubes, normalmente o VJ não sabe quais músicas serão tocadas pelo DJ, mas a estrutura da música eletrônica é previsível. Este tipo de música e suas vertentes - house, techno, trance, drum'n'bass - são regidas por batidas por minuto (bpm), em compassos compostos por dezesseis ou trinta e duas batidas, que marcam a entrada ou saída de elementos que as compõem. Sincronizar as imagens com a música portanto, é tarefa fácil e os próprios softwares permitem essa sincronia. Mas diferentemente do que acontece nas apresentações de jazz, não há diálogo entre o VJ e o DJ, pois este dificilmente está atento às imagens projetadas. Mia Makela observa que "os VJ s fazem com que as imagens reajam à música com bases rítmicas mais do que constroem performances audiovisuais onde imagem e som estão em diálogo constante" (MAKELA, 2006: 35 - traduzido). O VJ Alexis acredita que entrar em sintonia com 0 "clima" da música é igualmente importante, pois somente imagens pulsantes seguindo as batidas, torna a projeção desinteressante ${ }^{64}$. Para que isso aconteça os VJs apontam o feeling como elemento essencial durante a improvisação. O VJ Robson Victor atribui à sua experiência como DJ o fato de prever as possíveis variações que a música possa sofrer e dessa forma mixar as imagens mais adequadas $^{65}$. Já as performances audiovisuais são executadas geralmente por

\footnotetext{
${ }^{64}$ Declaração em entrevista concedida no dia 3 de dezembro de 2007, gravada em vídeo.
}

${ }^{65}$ Declaração em entrevista concedida no dia 20 de novembro de 2007, pela internet. 
duplas compostas por DJ e VJ. Neste caso há diálogo entre os artistas, pois ambos têm conhecimento prévio do que será apresentado, muitas vezes com marcações pré-determinadas para viradas, efeitos e transições.

Umberto Eco discorre sobre o improviso na transmissão direta de televisão, que segundo o autor, é "uma montagem improvisada e simultânea ao fato captado e montado" (ECO, 2005:182) e a compara a uma jam-session, onde os componentes improvisam "dentro de uma linha de congenialidade que Ihes permite uma criação coletiva, simultânea, extemporânea e todavia orgânica" (ECO, 2005:185). Machado também observa que diferentemente dos meios audiovisuais anteriores, na televisão ao vivo o controle do material transmitido é realizado no próprio ato da emissão, concluindo que "a tentativa se confunde com o resultado, o ensai o com o produto final" (MACHADO, 2000:131). Essa mistura entre tentativa e resultado pode ser constatada no VJ ing, mas ao contrário do que ocorre em uma transmissão direta de televisão, o processo de pré-produção existe, já que a captação e o tratamento das imagens são anteriores à montagem ao vivo.

Outra característica importante das jam-sessions é a participação do público durante a performance. Conforme relata Carlos Calado, o jazzman utiliza a improvisação para se expressar à platéia, que "ao receber essa expressão sob a forma de música, também se manifesta e interfere no processo, aplaudindo um solo, batendo palmas e pés, dançando ou mesmo gritando" (CALADO, 1989:18-19). Processo semelhante acontece nas pistas de dança, onde a reação do público funciona como referencial para que o VJ defina cores, efeitos, velocidade e repetição das imagens projetadas. Esta relação será mais bem detalhada no próximo capítulo. 


\section{0 processo em si: a mixagem ao vivo}

Como já mencionado anteriormente, durante a projeção e manipulação de imagens ao vivo, as características do espaço onde acontece a apresentação: tamanho, iluminação, quantidade e disposição de telões ou outros suportes de projeção, juntamente com a música tocada pelo DJ, determinam o tipo de fruição do público. Ambientes como clubes noturnos - telas múltiplas, som alto e pessoas dançando - tendem a estimular os sentidos, ao mesmo tempo em que provocam uma certa dispersão. Processo semelhante ao que Giselle Beiguelman aponta como a desespetacularização da arte, decorrente do "contexto de fruição pautado pelo nomadismo da cultura da mobilidade" e pelo estilo multitarefa do homem contemporâneo, que dirige, fala ao celular, envia torpedos, tudo simultaneamente. Nesse contexto, a arte estaria infiltrada no cotidiano e seria uma arte para não ser vista. (BEIGUELMAN in http:// pphp.uol.com. br/ tropico/ html/ textos/2707, 1. shl).

Na teleintervenção urbana de Beiguelman "Poétrica" 66 , o público podia intervir nos painéis eletrônicos situados em avenidas da cidade de São Paulo via web e enviando mensagens SMS, que eram automaticamente disponibilizadas na galeria do site. A obra era vista pelos passantes enquanto estes dirigiam, caminhavam ou faziam outras coisas. Embora Beiguelman não esteja fazendo referência imediata ao VJing, é possível lançar a dúvida sobre a recepção da obra pelo público, já que nos ambientes onde ocorrem as projeções, ele vê (ou não) as imagens ao mesmo tempo em que se movimenta no espaço. É interessante observar, contudo, que é através dessa movimentação que a participação acontece.

Diferentemente de trabalhos artísticos que possuem dispositivos tecnológicos para que o público interfira diretamente na produção da obra, a participação no VJ ing é mais sutil, até mesmo sem intenção, mas não menos importante para o resultado da performance. Segundo Moran, a passividade deixa de existir no momento em

\footnotetext{
${ }^{66}$ Poétrica, um work in progress, teve início em outubro de 2003, na Galeria Vermelho, em São Paulo e término em fevereiro de 2004, no Kulturforum, em Berlim.
} 
que o espectador é convidado a se deslocar no espaço multimídia, diferentemente do que acontece em um espetáculo tradicional (MORAN, 2004:5). E "a ocupação deste espaço físico concreto cria diversos espaços e tempos em função da dinâmica e proposta das projeções", onde o espectador vivencia a relação dos telões com 0 espaço circundante, que passa a ser preenchido por luzes, cintilações e sons (MORAN, 2003: 96).

A vibração do público interfere tanto na seleção de músicas tocadas pelo DJ quanto na manipulação realizada pelo VJ, que no momento da apresentação escolhe as imagens dentre as disponíveis em acervo previamente selecionado. Silvia Laurentiz destaca "a recepção destas imagens participando ativamente de sua criação, pois a sintonia da imagem-som, o modo como ela é recebida, o 'calor da platéia', o ritmo do local, o 'aqui-e-agora', irão conduzir o desenrolar da construção sígnica nas telas" (LAURENTIZ, 2004:5).

Por serem fruto da convergência entre som, imagem, ambiente e público em tempo real, as performances se constituem em obras únicas, impossíveis de serem revividas. Essa característica tem sido apontada como diferencial ao comparar-se o VJing com outras artes que também privilegiam a sincronia entre som e imagem, como o videoclipe. Mark Coniglio acredita que "o que dá vida à performance é 0 fato dela não ser a mesma todas as noites" (2005:87 - traduzido). Segundo ele, mesmo que as imagens projetadas sejam gravadas, o fato destas serem manipuladas em tempo real, faz com que o resultado final nunca seja o mesmo. Mello afirma que o fato do VJing ser "uma arte não-objetual, transitória, impermanente, uma arte da vida, ao incluir o espectador na trama de significados por ela gerados" o diferencia de "uma arte relacionada a um produto específico ( como um videoclipe)" (MELLO, 2004:64). É importante ressaltar porém, que a participação do público não é individual. Se dá coletivamente, através da massa conectada em uma experiência compartilhada, possível somente naquela hora e lugar, onde, segundo o VJ Peter Mettler ${ }^{67}$, "o ambiente alimenta a

${ }^{67}$ Peter Mettler é VJ ocasionalmente e diretor de documentários como Pictures of Light (1994) e Gambling, Gods and LSD (2002). A declaração citada foi concedida em entrevista para o livro The VJ Book, de Paul Spinrad. Informações completas na bibliografia. 
mixagem e a mixagem alimenta o ambiente" (2005:15 - traduzido).

Nesse cenário, qualquer registro do VJing se transforma em uma tentativa frustrada de exibição da obra. Em 2005 foi lançada a coletânea VJ BR ${ }^{68}$ em DVD, com trabalhos de vinte VJ s brasileiros acompanhados por trilhas compostas, em sua maioria, por DJ S. Independentemente do valor estético dos vídeos apresentados, verifica-se que ao se eliminar o espaço, o público e o "ao vivo" dos trabalhos, perde-se a essência do VJing. O resultado é um outro tipo de obra audiovisual, onde o espectador passivamente assiste às imagens em uma única tela, uma obra acabada, mais próxima do videoclipe do que do vídeo ao vivo.

Em um futuro próximo é provável que os eventos passem a privilegiar uma interferência maior por parte do público nas imagens projetadas, pois já é possível acionar trechos de vídeos via bluetooth através de celulares, i-Phones e acessórios para videogames como a P5 game glove, uma luva para jogos de realidade virtual que no VJing pode ser usada como um controlador MIDI, associando-se os movimentos da mão ao software ou ao banco de imagens. O VJ Albuk também utilizou o MIDI para adaptar um dance pad - tapete com sensores para jogos de dança do videogame Playstation 2 - e controlar imagens e efeitos com os pés. Por enquanto, essas experimentações não foram disponibilizadas ao público presente nas apresentações. Um exemplo de interação é a "Performance-VJing-Wireless", realizada pela dupla $\mathrm{mm}$ não é confete no evento $4 \mathrm{Hype}^{69}$. Duas pessoas trajadas com roupas especiais - um monitor acoplado ao peito e uma microcâmera na mão circulavam por entre o público e registravam as imagens, transmitidas através de dispositivos sem fio para o computador onde a dupla se encontrava. Essas imagens eram então mixadas e projetadas no telão.

${ }^{68}$ O DVD VJ BR1 - Visual J ockeys do Brasil foi organizado por Lucas Margutti, Guilherme Albuquerque e Ruth Slinger.

${ }^{69}$ O 4Hype foi realizado em maio de 2005 no Sesc Pompéia, São Paulo. 


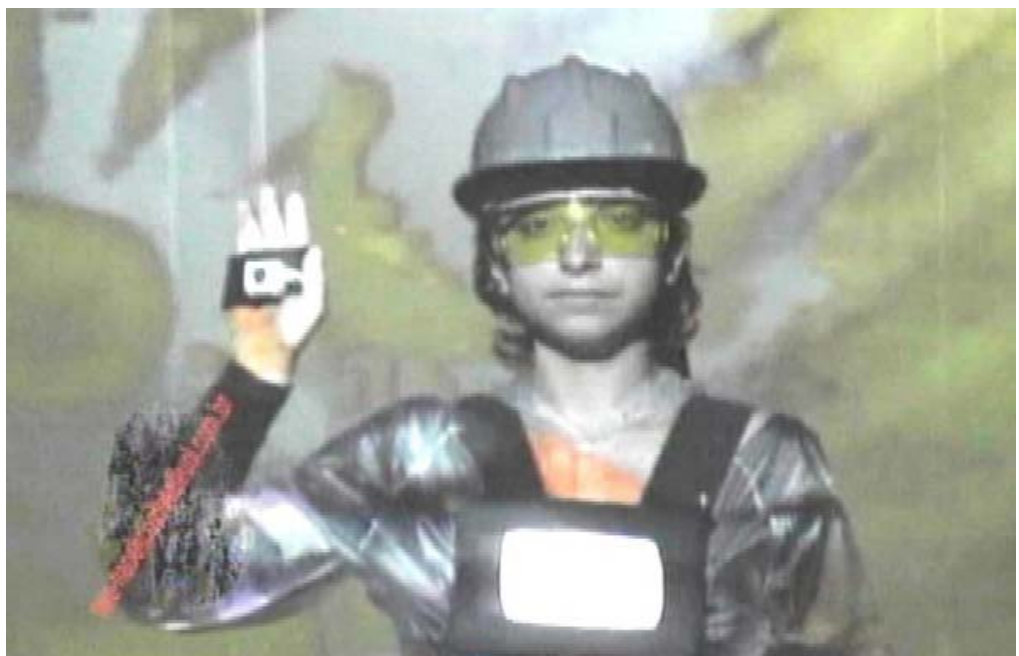

Figura 26 - "Performance-VJ ing-Wireless", da dupla mm não é confete. 


\section{O diálogo entre linguagens}

É possível estabelecer relações entre o VJing e outras linguagens artísticas contemporâneas, como a arte sonora, o grafitti eletrônico, a web art, mobile art, intervenções urbanas, games, instalações interativas e vídeos com estética similar.

O vídeo "Poses do 19"70, de Gavin Adams, Vânia Carvalho e Solange Lima, é composto por 1.338 retratos do fotógrafo Militão Augusto de Azevedo, pertencentes ao acervo do Museu Paulista. Os retratos, tirados entre 1862 e 1885, são em formato "cartão de visita" $(11 \times 6 \mathrm{~cm})$, muito popular na época. No vídeo eles foram justapostos e seqüenciados pelo alinhamento dos olhos dos fotografados, sendo que alguns foram ampliados ou reduzidos para melhor se encaixarem uns com os outros, além de serem submetidos a uma padronização de cores. Foram também organizados segundo poses - em pé, sentados, encostados -, gênero e faixa etária. A seqüência de retratos, editados em velocidade rápida no ritmo da trilha eletrônica composta por Adams, cria a ilusão de movimento e em alguns momentos os retratados parecem estar dançando. Algumas frases foram inseridas para ressaltar regras comportamentais ou padrões sociais da época, como por exemplo: "de quem é a cadeira?", seguida de fotos de casais onde os homens estão sempre sentados ao lado de suas esposas, que posam em pé. 0 ritmo acelerado das imagens e os movimentos repetitivos, seguindo a batida marcada da música, lembram a linguagem lançada na pista pelos VJ S.

\footnotetext{
${ }^{70}$ A direção artística e a trilha de Poses do 19 (2002) é de Gavin Adams. O roteiro e a direção científica, de Solange Lima e Vânia Carvalho.
} 

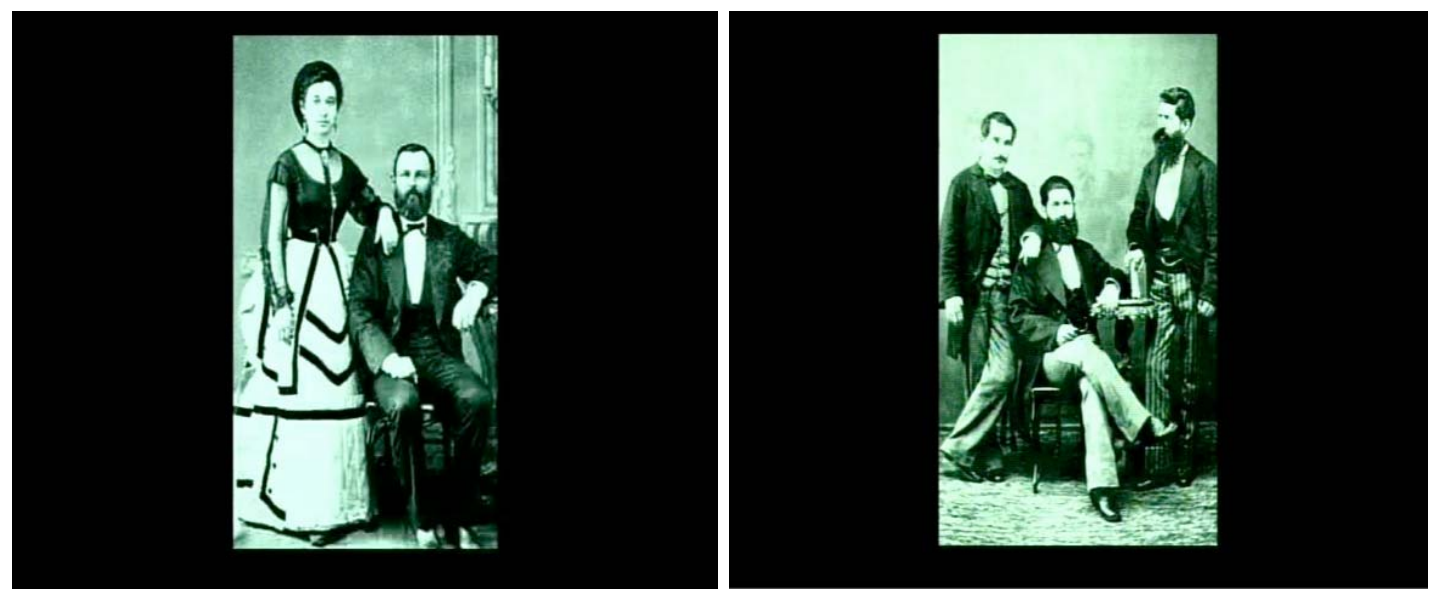

Figura 27 - "Poses do 19": de quem é a cadeira?

"Wild Life", da norte-americana Karolina Sobecka, foi exibida no FILE $2007^{71}$ como um graffiti eletrônico. Na intervenção urbana, um carro em movimento projetava a animação de um tigre nas paredes dos prédios da cidade. Os movimentos do animal eram programados para corresponder à velocidade do automóvel. 0 tigre corria, se o carro acelerava e parava, se o mesmo brecava. A obra possui semelhanças com o trabalho da brasileira Regina Silveira, "Super-Herói Night and Day" ${ }^{72}$, em que um super-herói era projetado em raios laser na fachada de edifícios em São Paulo.

O grafitti eletrônico tem sido bastante explorado pelo Graffiti Research Lab ${ }^{73}$, de Nova York. Entre outros trabalhos de intervenção urbana, o grupo grafita com caneta laser. Uma câmera capta a área de projeção, enquanto um programa instalado em um laptop reconhece a luminosidade do laser e envia o sinal para um projetor de grande potência, que reproduz a imagem na parede.

\footnotetext{
${ }^{71}$ O FILE 2007 foi realizado entre os dias 13 de agosto a 09 de setembro, sob organização de Ricardo Barreto e Paula Perissinotto, no Sesi Paulista.

${ }^{72}$ Super-Herói Night and Day foi realizada em 1997 na Av. Paulista e posteriormente em Buenos Aires (1999) e Puerto Rico (2000). Foi reapresentada na Virada Cultural, em São Paulo, em maio de 2007.

${ }^{73}$ http:// graffitiresearchlab. com, acessado em 20.jan. 2008.
} 
O VJ Alexis e o núcleo ativista TEMP também fizeram uso da projeção em um protesto contra a reintegração de posse do Edifício Prestes Maia, situado no centro de São Paulo e habitado por duas mil pessoas ${ }^{74}$.

E há ainda a TagTool ${ }^{75}$, conjunto de software e hardware open source ${ }^{76}$ desenvolvido para a criação de desenhos e animações em tempo real. Composta por PC, monitor, tablet ${ }^{77}$, um joystick de videogame, sliders de efeitos e um botão vermelho para salvar as imagens, a ferramenta é uma mistura de analógico e digital. O usuário desenha na tablet, aperta o botão vermelho para salvar a imagem e utiliza o joystick para movimentá-la. As funções são controladas por um programa chamado Nodekit. Durante as apresentações, conecta-se a TagTool a um projetor. Um de seus criadores, o austríaco Markus Dorninger, esteve em São Paulo ${ }^{78}$ e, juntamente com o VJ Spetto, "desenhou" nos prédios da cidade.

Embora não incorporem sons durante as apresentações, a efemeridade dessas projeções no cenário urbano e a multiplicidade de estímulos a que o espectador está submetido, assim como no VJing, remetem à arte infiltrada no cotidiano e ao conceito de desespetacularização apontado por Beiguelman, já mencionado no capítulo 5.

\footnotetext{
${ }^{74}$ A projeção, denominada pelos artistas de video-grafitagem, ocorreu no dia 06 de outubro de 2005.

75 tagtool.org, acessado em 20.jan. 2008.

${ }^{76}$ Programas com código aberto, criados e disponibilizados para uso do público.

${ }_{77}$ Prancheta para criação de desenhos em programas de computador.

${ }^{78}$ Visita realizada em janeiro de 2008. Informações obtidas em matéria de Fabiana Bártholo (VJ Bete Rum), disponível no http://br. noticias. yahoo.com/s/15012008/11/entretenimento-tecnologiaentretenimento-multisensorial.html, acessado em 21 de janeiro de 2008.
} 

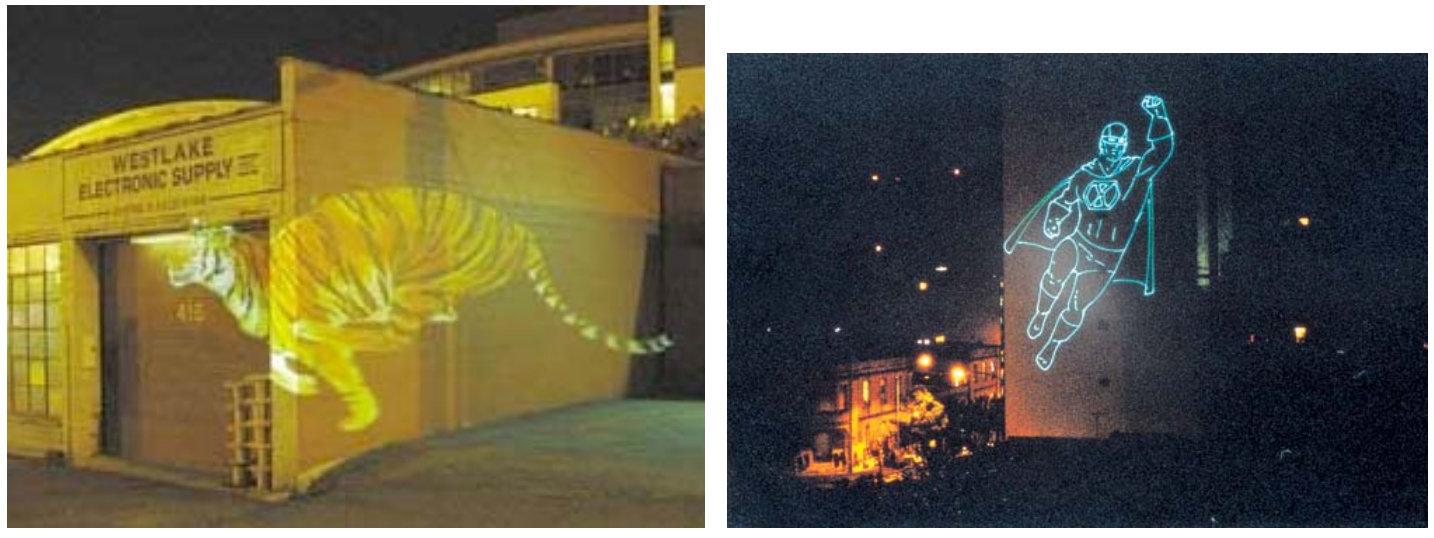

Figura 28 - "Wild Life”, de Karolina Sobecka. Figura 29 - "Super-Herói”, de Regina Silveira.
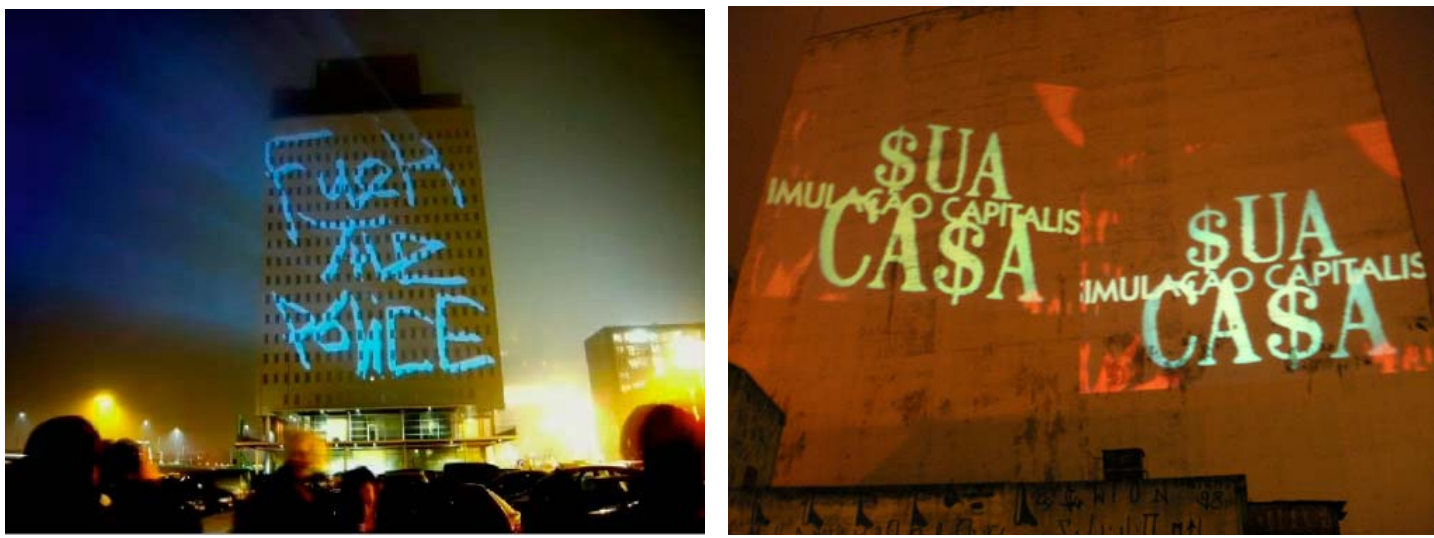

Figura 30 -"Laser Tag”, Grafitti Research Lab. Figura 31 -VJ Alexis/TEMP no Edifício Prestes Maia.

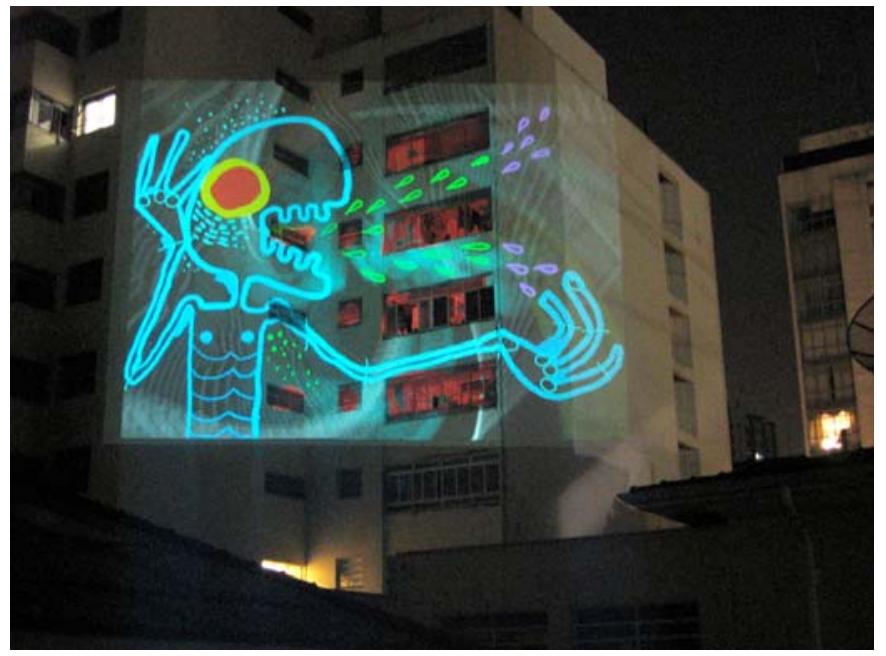

Figura 32 - VJ Spetto, Alexis e Markus Dorninger "desenhando" com a TagTool. 
"Circ_lular/mobil_izing", do grupo Preguiça Febril ${ }^{79}$, é um sistema de "webjaying" que possibilita a mixagem online de imagens, sons, trechos de filmes, vídeos e textos disponíveis em um banco de dados aberto para qualquer pessoa. O conteúdo pode ser mixado em tempo real na web e nos locais onde a obra é exposta. Em comum com o VJing, além do acervo de imagens disponível em banco de dados e a mixagem em tempo real, o trabalho suscita a questão da autoria, através da sampleagem de imagens, sons e textos de fontes diversas que recombinados, geram novos significados.

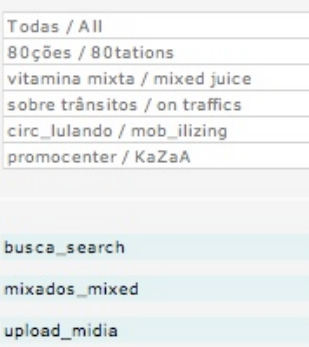

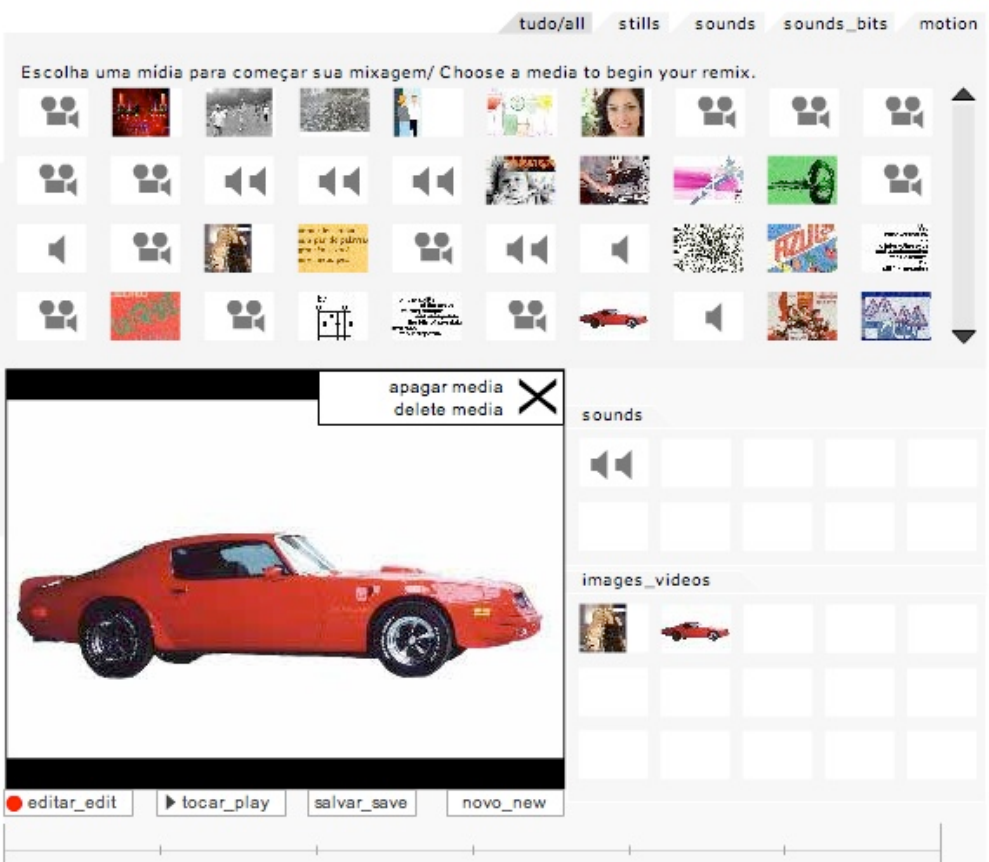

Figura 33 - Interface do "Circ_lular/ mobil_izing", do Preguiça Febril.

\footnotetext{
79 O Preguiça Febril é composto por Giselle Beiguelman, Marcus Bastos e Rafael Marchetti. A obra citada estreou no Sónar Sound, no Instituto Tomie Ohtake São Paulo, em setembro de 2004.
} 
No espetáculo "Video Games Live" 80 , promovido pelo maestro norte-americano Jack Wall e o compositor Tommy Tallarico, uma orquestra executa ao vivo trilhas de games como Tomb Raider, Zelda, Mario Bros, entre outros clássicos, acompanhadas da exibição de imagens gravadas em telões e efeitos de iluminação. Os músicos tocam em sincronia com as imagens projetadas e a apresentação conta com alguns momentos interativos, quando pessoas da platéia são convidadas a jogar com sensores acoplados ao corpo. Nesse momento de improviso, a orquestra não se esforça para acompanhar as imagens. Apesar de não haver edição ao vivo, a simultaneidade entre som e imagem no ambiente remete ao VJing. O diálogo entre as linguagens também se estabelece quando um VJ projeta imagens de games, joga ao vivo ou utiliza acessórios (como a já citada P5 game glove) durante sua performance. Como lembra Spinrad, um exemplo dessa relação é o game Auto Modellista, que possui o recurso "VJ mode" para aplicar efeitos nos jogos gravados (SPINRAD, 2005:138).

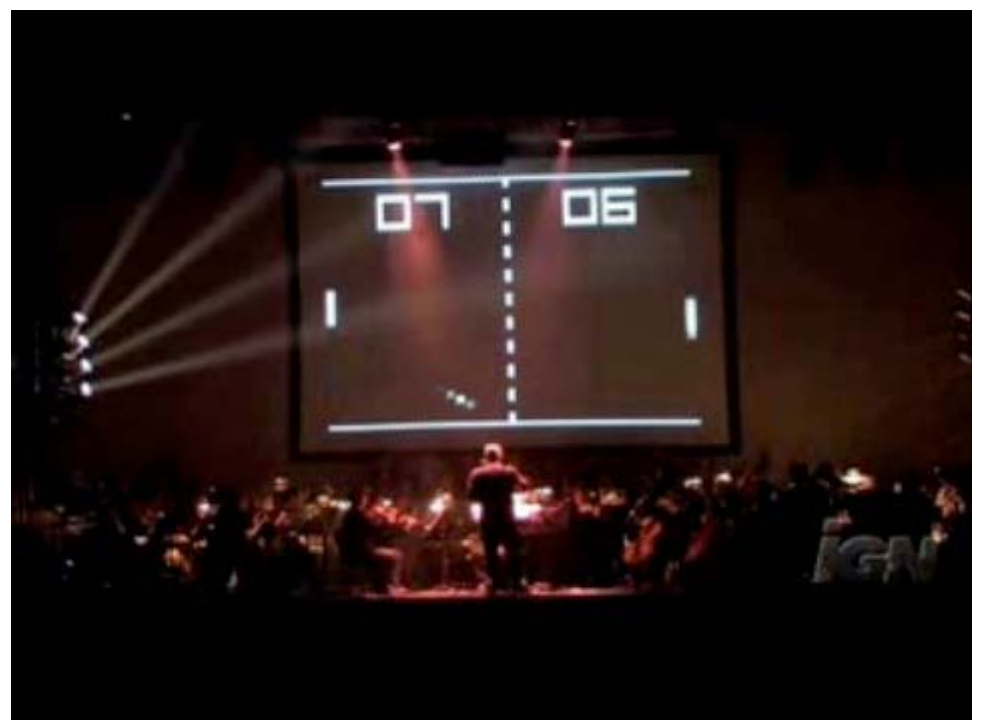

Figura 34 - apresentação do "Video Games Live"

\footnotetext{
${ }^{80}$ A 2a edição do evento no Brasil aconteceu em São Paulo, em 16 de setembro de 2007, no Via Funchal, com a participação da Orquestra Petrobrás Sinfônica e coral.
} 
"Tecnopathos" foram espetáculos apresentados pelo grupo de mesmo nome no teatro da Estação Ciência, em São Paulo ${ }^{81}$. As performances misturavam dança, teatro, artes plásticas, tecnologia e as bailarinas interagiam com imagens tridimensionais em cibercenários criados por Tânia Fraga. Em algumas apresentações, a artista manipulava os cenários em tempo real e em outras, as bailarinas Andrea Fraga e Marinês Calori carregavam um mouse sem fio, "dialogando" com as imagens. A projeção e manipulação de imagens ao vivo realizada pelos VJs também pode ser executada em espetáculos de dança. 0 coletivo Bijari, por exemplo, foi responsável pelas imagens do espetáculo "Desatino do Norte, Desatino do Sul" ${ }^{82}$, com o corpo de baile do Balé da Cidade de São Paulo e a participação do DJ Dolores e Orchestra Santa Massa executando a trilha ao vivo. O integrante Giuliano Scandiuzzi afirma que eles acompanharam vários ensaios para poderem sincronizar 0 vídeo ao balé com precisão e adequação ${ }^{83}$.
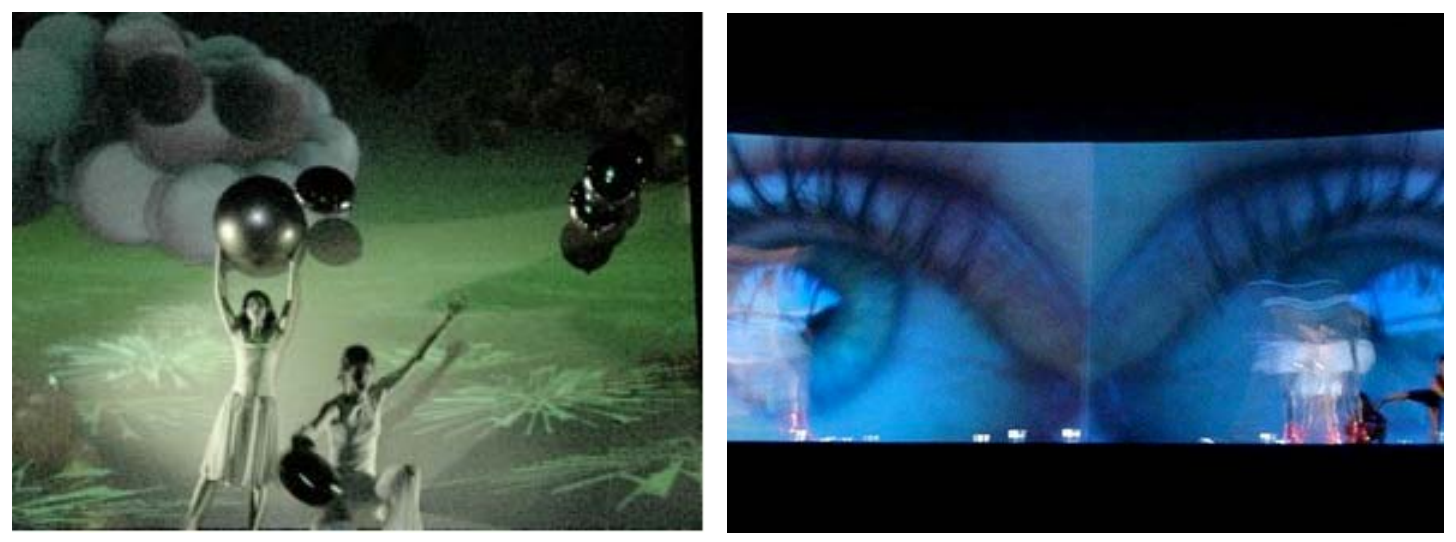

Figura 35 - "Tecnopathos", do Tecnopathos. Figura 36 - "Desatino do Norte, Desatino do Sul", com o Bijari.

\footnotetext{
${ }^{81}$ As apresentações aconteceram em novembro de 2006. O grupo Tecnopathos é formado por Tânia Fraga, criadora dos cibercenários, Andrea Fraga e Marinês Calori (bailarinas), Miguel Paladino (consultor cênico) e Cauê Matos (direção e produção).

${ }^{82} \mathrm{O}$ espetáculo foi coreografado por J orge Garcia e exibido no Theatro Municipal de São Paulo, em abril de 2003.

${ }^{83}$ Declaração para a matéria "Império dos Sentidos" - Revista Simples, n21, edição mai/jun 2003.
} 
O artista multimídia uruguaio radicado no Brasil, Fernando Velázquez, realizou a performance de live images denominada "SP_remix_2.0" na exposição coletiva "Homens Trabalhando" ${ }^{84}$, onde vários artistas exibiram suas criações em um prédio em obras na cidade de São Paulo. O público conferia os trabalhos em meio a materiais de construção e operários que circulavam pelo local. Na apresentação de Velázquez, imagens gravadas no dia-a-dia da obra foram mixadas a outras de seu acervo - composto inclusive por imagens de terceiros -, como placas, antenas, aviões, entre outros ícones urbanos e projetadas em telões. Na produção e manipulação das imagens, foram utilizados os programas Isadora e Modulat8. 0 som, a cargo do músico uruguaio Francisco Lapetina, também era manipulado em tempo real. Através de uma partitura audiovisual escrita durante os ensaios, buscava-se a sincronia entre imagens e sons, sem eliminar o improviso característico das performances ao vivo. Neste trabalho, todos os elementos do VJing estão presentes: a manipulação de áudio e vídeo em tempo real, a utilização de banco de imagens, a sincronia entre som e imagem - semelhante aos AV sets -, o improviso e os programas utilizados pelos VJs. Ao invés da pista, o prédio em construção como cenário.

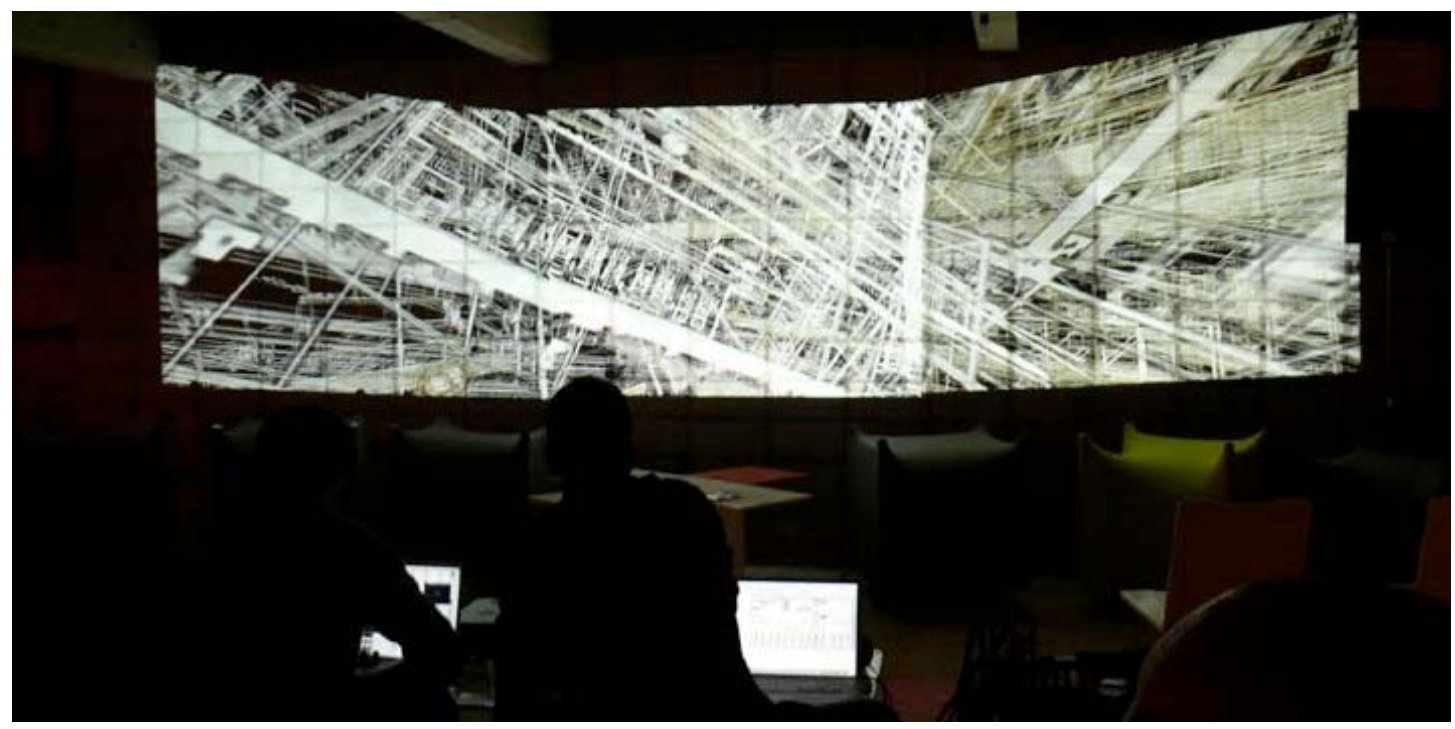

Figura 37 - "SP_remix_2.0", de Fernando Velázquez, na exposição "Homens Trabalhando".

\footnotetext{
${ }^{84}$ Exposição realizada em um canteiro de obras na Rua Harmonia, na Vila Madalena, promovida pela galerista Florence Antonio em conj unto com a Triptyque Arquitetos, em agosto de 2007.
} 
Outra obra de Velázquez, "SP_Mobile" - realizada em conjunto com o espanhol Nacho Durán e o músico Francisco Lapetina -, foi apresentada durante o Motomix $2007^{85}$. Neste trabalho, o instrumento utilizado para produção das imagens e interação com as mesmas, era o celular. O público, posicionado em frente ao telão, modificava as imagens projetadas movimentando os celulares fornecidos pelos monitores do evento. Através de um programa específico, uma câmera posicionada acima do telão rastreava as telas dos aparelhos, possibilitando assim a alteração de vídeos e sons conforme os usuários se deslocavam no espaço. As imagens que compunham o banco de dados foram captadas com câmeras de celulares pelos integrantes das ONGs selecionadas para participar do workshop que antecedeu a apresentação. Apesar da entrada das imagens na tela ser orientada por um programa, a estética de apresentação dessas imagens, resgatadas do banco de dados, dialoga com o VJing.

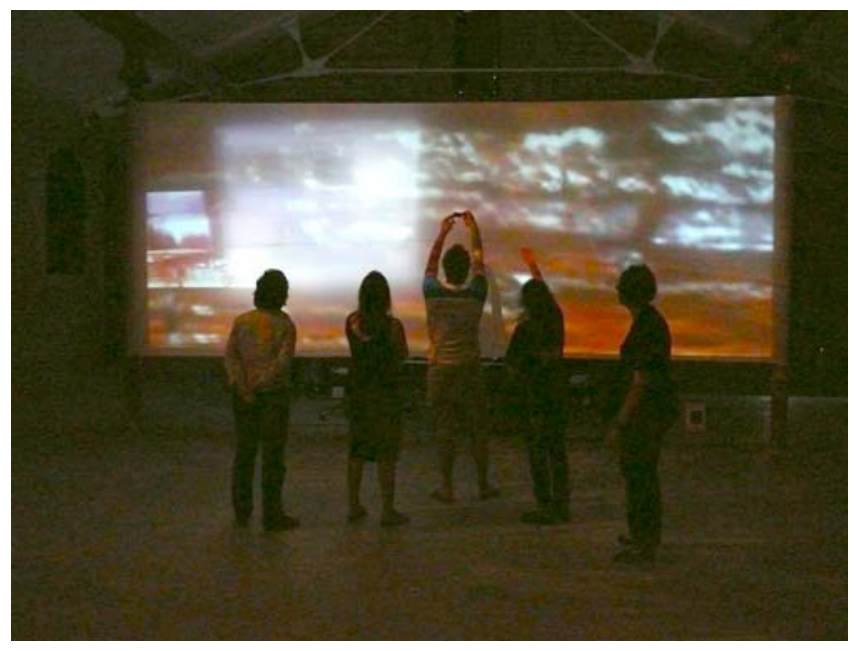

Figura 38 - "SP_Mobile", de Fernando Velázquez, Nacho Durán e Francisco Lapetina.

\footnotetext{
${ }^{85}$ A Mostra de Artes Visuais Motomix foi realizada de 28 de novembro a 03 de dezembro de 2007, na Cinemateca Brasileira, em São Paulo.
} 
Também era por meio do celular que o público interagia em "Self Cinema", trabalho de Vera Bighetti exibido no Nokia Trends $2007{ }^{86}$. A instalação lembrava uma pista de dança cercada por telões e as pessoas que entravam no espaço eram filmadas pelos celulares fornecidos pelos monitores ou pelo próprio aparelho, caso tivessem baixado o software que converte 0 aparelho em uma webcam, disponível para download no site da artista ${ }^{87}$. As imagens eram enviadas ao computador, processadas e transformadas em imagens estereoscópicas, visualizadas com o uso de óculos 3D. Fones de ouvido também estavam disponíveis e um sensor avisava o usuário se alguém no local compartilhava a mesma música. A obra buscava integrar o corpo do espectador ao ambiente e estimular a percepção sensória em um processo de rotinas auto-generativas.

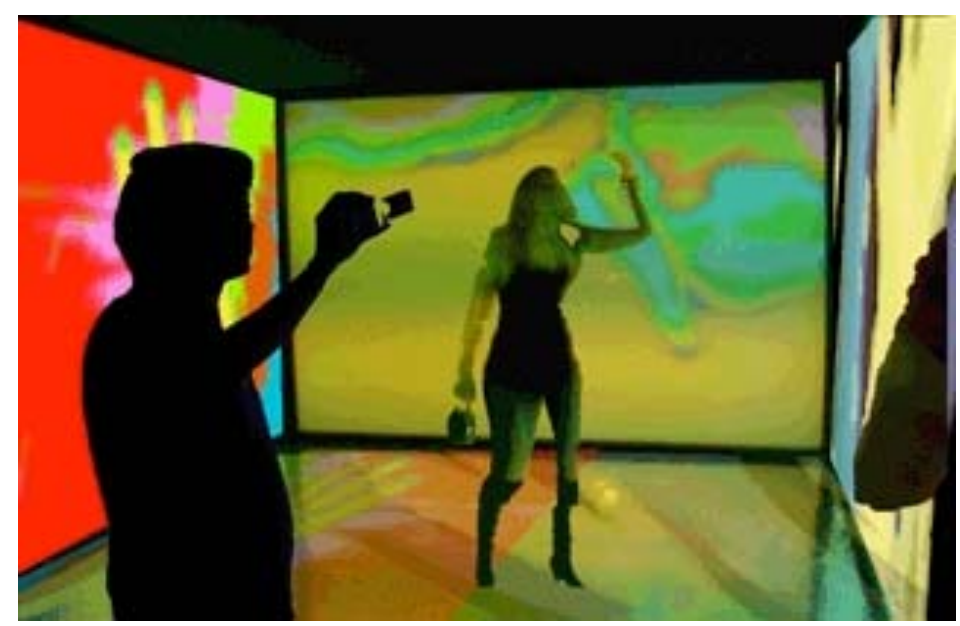

Figura 39 - "Self Cinema", de Vera Bighetti.

${ }^{86}$ O Nokia Trends foi realizado em 08 de dezembro de 2007, no Memorial da América Latina, São Paulo.

${ }^{87}$ www. artzero. net, acessado em 20.jan.2008. Para baixar o software era preciso modelo específico da Nokia. 
Outro exemplo de trabalho que incorpora o celular é "De Vez em Sempre" ${ }^{88}$, de Giselle Beiguelman. Na projeção interativa, o público captava imagens com câmeras de celular e as enviava aos telões via bluetooth. Ao passar o mouse sobre as telas disponíveis no ambiente, as imagens eram manipuladas, desconstruídas, decompostas em frames que se reordenavam através da movimentação que 0 interator realizava com o mouse. Quando o público parava de interagir, os vídeos recomeçavam, sem apagar os registros que haviam na tela - um mosaico de imagens criado pelos participantes. Este trabalho de Beiguelman, assim como "SP_Mobile" e "Self Cinema", mostram possibilidades de interação do público com as imagens que podem ser incorporadas nas performances de VJ ing.

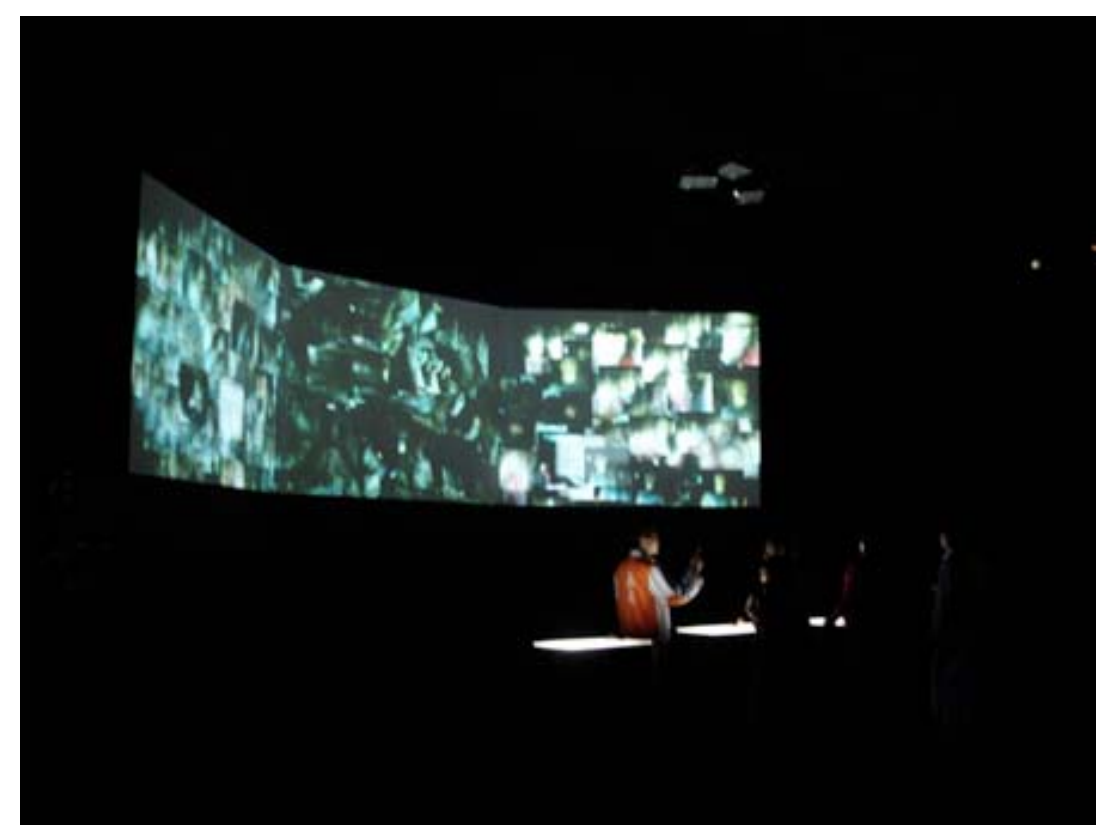

Figura 40 - "De Vez em Sempre", de Giselle Beiguelman.

88 "De vez em Sempre" foi exibida no Life Goes Mobile, evento integrante do Nokia Trends, em 2005, sob curadoria de Lucas Bambozzi. No FILE 2005 Beiguelman apresentou "De Vez em Nunca", um complemento à obra citada. 
A obra de arte sonora "Teia", do grupo m-u-r-o ${ }^{89}$, exibida no FILE 2007, teve início com a construção - realizada por dois performers - de uma "teia" de fita adesiva, em uma estrutura com formato de cubo. Os sons das fitas sendo arrancadas dos rolos e coladas na estrutura eram capturados por microfones sem fio e manipulados em tempo real no programa MAX. Quando a construção da "teia" terminava, os performers saíam do palco, mas o som das fitas continuava, através da manipulação dos sons capturados. Começava então a projeção de uma animação na estrutura, produzida com imagens da "teia" filmadas durante os ensaios e posteriormente manipuladas no software GePhex, também utilizado pelos VJs. 0 objetivo era explorar as características sonoras, como o processo de construção e o som da fita adesiva, e as visuais: o próprio objeto, as sombras provocadas pela iluminação e a imagem projetada.

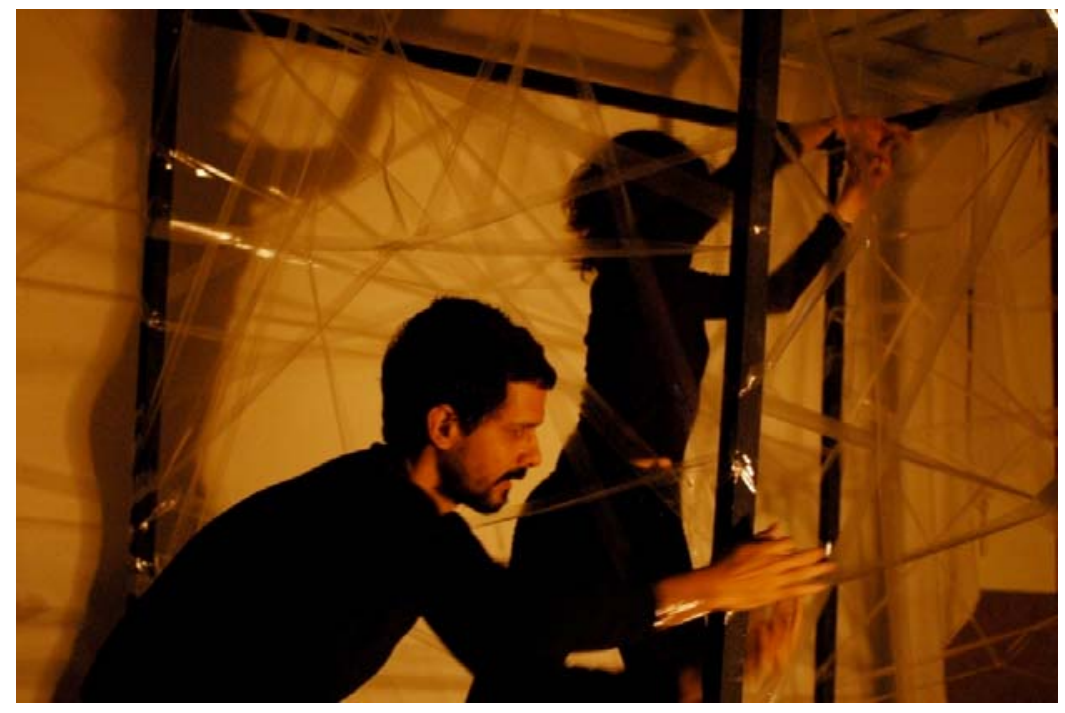

Figura 41 - Performance "m-u-r-o", no FILE 2007.

\footnotetext{
${ }^{89}$ A obra foi concebida por Alexandre Fenerich, Alexandre Porres, Andrei Thomaz, Giuliano Obici, Lilian Campesato, Patrícia Francisco, Valério Fiel da Costa e Vitor Kisil e exibida no dia 14 de agosto no Festival Hipersônica, sob curadoria de Hermano Vianna e Ronaldo Lemos. O Hipersônica fez parte da programação do FILE 2007, sob curadoria geral de Ricardo Barreto e Paula Perissinotto.
} 
"Suspensão" 90 é um trabalho de live images de Luiz Duva. A performance começa com uma ação física do próprio artista, que salta no palco. Em seguida ele assume o comando dos equipamentos - laptop, teclado, controlador MIDI - e passa a manipular imagens pré-gravadas da mesma ação no programa Isadora, acrescidas de imagens geradas ao vivo e sons simultaneamente, em tempo real. A proposta é fazer um contraponto entre a impossibilidade de um corpo se manter suspenso no ar e a viabilidade de realizar esta ação virtualmente, através da criação de novas imagens e sons a partir de uma mesma imagem original, formando assim uma composição audiovisual. Como em algumas apresentações audiovisuais de VJ S, 0 som é gerado a partir das imagens, misturados a samplers de outras músicas e ruídos diversos. A improvisação também está presente nos diálogos entre sons e imagens, fazendo com que uma apresentação nunca seja exatamente igual a outra. Duva licenciou a obra no Creative Commons ${ }^{91}$ e disponibilizou os aúdios e vídeos utilizados, assim como a vídeo-partitura, mapa de palco, entre outras informações, na galeria virtual noema ${ }^{92}$.

\footnotetext{
${ }^{90}$ Suspensão 1 - realizada no ON_OFF, no Instituto Cultural Itaú, São Paulo, como parte da exposição Emoção Artificial, com curadōia de Roberto Moreira, em junho de 2006. Suspensão 2 interconnect@between attention and imersion, no ZKM, Alemanha, com curadoria de Daniela Bousso, em setembro de 2006. Suspensão 3 - Proj eto Mutiplicidade, no Centro Cultural Telemar, Rio de J aneiro, com curadoria de Batman Zaraveze, em maio de 2007 e Suspensão 4 - 1o Festival de Curta Metragem de Direitos Humanos, no Centro Cultural São Paulo, em maio de 2007.

${ }^{91} \mathrm{O}$ Creative Commons é um proj eto que tem por objetivo expandir a quantidade de obras criativas disponíveis ao público, permitindo criar outras obras a partir destas, compartilhando-as. Mais informações: www. creativecommons. org.br

${ }^{92}$ http:// www. noema. art. br/ susp/ about. html, acessado em 20.jan. 2008.
} 


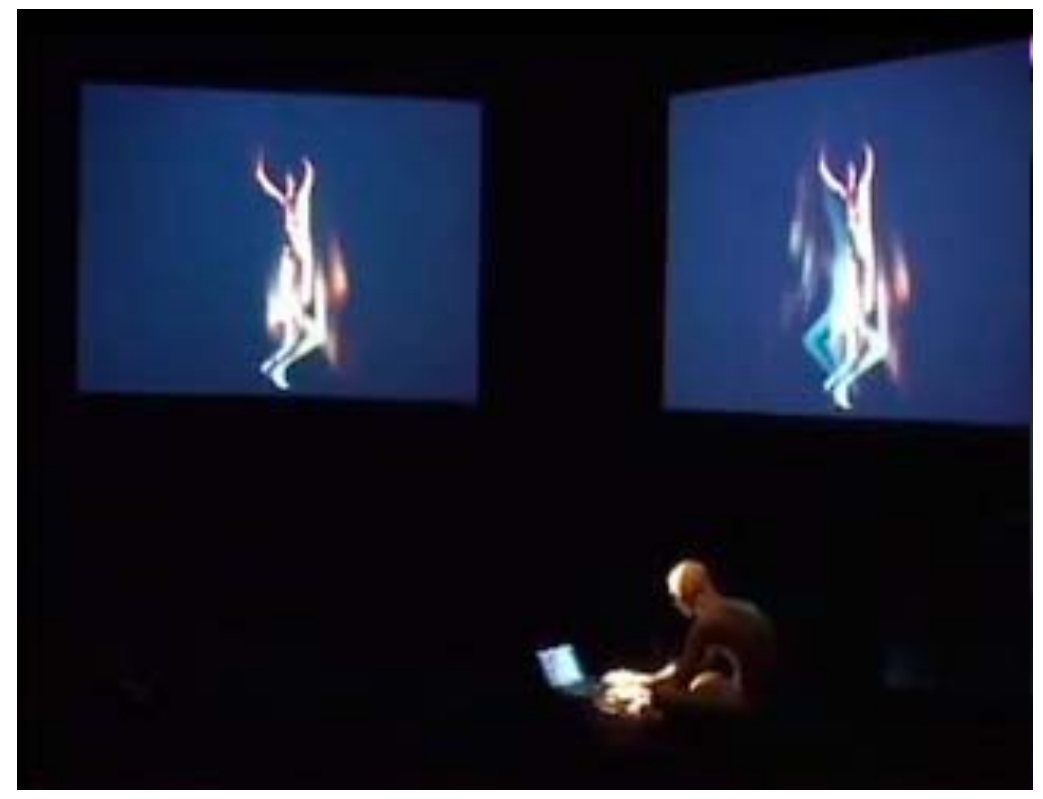

Figura 42 - "Suspensão”, de Duva. 


\section{CONSIDERAÇÕES FINAIS}

Nascida nas pistas de dança de raves e casas noturnas pertencentes ao circuito underground da música eletrônica, a arte de VJing rapidamente se expandiu e conquistou espaço em festivais patrocinados por grandes marcas e eventos próprios do circuito das artes. A facilidade de acesso a programas e equipamentos, assim como o intercâmbio de informações online via sites e listas de discussão, favoreceram a eclosão e o crescimento da cena. Mas a tecnologia por si só não garante a criação de trabalhos consistentes. As propostas de cada VJ dependem de suas referências, fontes de pesquisa, modos de captação e tratamento das imagens, intenções artísticas e posicionamentos críticos.

A análise das imagens e suas relações, baseada no contexto da arte e tecnologia e nos artigos acadêmicos existentes sobre VJing, assim como nas entrevistas realizadas com os artistas e na observação das performances ao vivo, suscitam questionamentos sobre hibridização, narrativa, autoria, recombinação, ambiente, sinestesia, improviso, compartilhamento e interação. Neste sentido, o DVD anexo com o vídeo "VJing: imagens da cena" - que sem a intenção de ser uma experimentação artística, registra algumas performances de $V$ Jing realizadas em casas noturnas, festivais e nos circuitos artísticos -, torna-se material importante de documentação e pesquisa.

Entre as características apontadas neste estudo, a hibridização se destaca por ser intrínseca à projeção e manipulação de imagens ao vivo. Hibridização entre as múltiplas influências artísticas que contribuíram para o surgimento do VJing, hibridização no processo de produção, onde imagens procedentes de diversas fontes são misturadas, na mixagem ao vivo, no diálogo com a música e nas relações que estabelece com outras linguagens contemporâneas. 
Verifica-se também que a relação entre 0 VJ ing e a linguagem musical vai além da tentativa de sincronia entre as imagens e a música tocada no momento das apresentações. A linguagem musical está presente no processo de produção das imagens, através do uso de softwares com lógicas e interfaces semelhantes aos programas musicais, na utilização de instrumentos via protocolo MIDI, nos samplers, no scratch e no remix, na recriação dos espaços onde as acontecem as apresentações, no improviso que remete às jam-sessions de jazz, onde o calor do público interfere no resultado da performance.

Diferentemente de outras linguagens, a participação do público durante as apresentações não acontece de forma individual, contemplativa ou através de algum dispositivo interativo. Ela se dá coletivamente, através da vibração da platéia, da movimentação dos corpos no espaço. E por serem resultado da convergência entre som, imagem, ambiente e público em tempo real, essas apresentações se caracterizam como obras únicas, impossíveis de serem revividas.

Com o crescimento da cena, ainda em expansão, novos modelos de projeção e manipulação de imagens ao vivo se configuram. É o caso das performances audiovisuais (AV sets) - onde vídeo e áudio são mixados em tempo real - e dos novos equipamentos e suportes utilizados para a projeção além do telão, distanciando cada vez mais o VJ ing do modelo tradicional de cinema.

As experimentações dos VJ $\mathrm{s}$, ao acionarem trechos de vídeo via bluetooth através de celulares ou utilizarem acessórios de videogame nas performances, sugerem que em breve haverá maior interferência do público nas imagens projetadas. 0 constante diálogo com outras linguagens contemporâneas como a web art, mobile art, intervenções urbanas, entre outras, indica ainda o surgimento de novas manifestações artísticas que futuramente ocuparão o lugar do VJing. E este passará a fazer parte dos antecedentes que contribuíram para a criação desses novos modelos. 


\section{REFERÊNCIAS BIBLIOGRÁFICAS}

BAMBOZZI, Lucas (2003). "Outros cinemas". In Kátia Maciel e André Parente (orgs.). Redes sensoriais: arte, ciência, tecnologia. Rio de Janeiro: Contra Capa Livraria, p. 61-75.

"O fenômeno da manipulação de imagens" in http://p. php.uol.com. br/ tropico/ html/ textos/2555, 1. shl, TRÓPICO, acesso em 23 de julho de 2006.

"A era do ready-made digital" in http:// p. php.uol.com. br/tropico/html/textos/ 1680, 1. shl, TRÓPICO, acesso em 23 de julho de 2006.

BEIGUELMAN, Giselle. "O micromínimo comum" in http:// pphp. uol.com.br/tropico/html/textos/2707,1.shl, TRÓPICO, acesso em 22 de outubro de 2006.

BELLOUR, Raymond (1997). Entre-Imagens, Foto, cinema, vídeo, São Paulo: Editora Papirus (1ed. Francesa em 1990). Tradução de Luciana A. Penna.

CALADO, Carlos (1989). J azz ao vivo. São Paulo: Perspectiva, Coleção Debates.

CASCONE, Kim (2000). "The asthetics of failure: 'post-digital' tendencies in contemporary computer music". Computer Music J ournal 24 (4), p.12-18.

COHEN, Renato (1989). Performance como linguagem. São Paulo: Perspectiva, Coleção Debates.

COSTA, Flávia Cesarino (2005). O primeiro cinema: espetáculo, narração, domesticação, Rio de J aneiro: Azougue Editorial.

COUCHOT, Edmond (2003). "A segunda interatividade. Em direção a novas práticas artísticas". In Arte e vida no séc XXI, Diana Domingues (org), São Paulo: Unesp, p. 27-38. 
(1993). "Da representação à simulação: evolução das técnicas e das artes da figuração", in: Imagem-Máquina: a era das tecnologias do virtual, André Parente (org), São Paulo: Editora 34, p.37-47.

DOMINGUES, Diana (1993). "A Imagem eletrônica e a poética da metamorfose". São Paulo: Comunicação e Semiótica/ PUC, tese de doutorado.

ECO, Umberto (2003). Obra aberta, São Paulo, 9ạedição: Perspectiva, Coleção Debates. Tradução de Giovanni Cutolo.

EMMERSON, Simon. (2001). "From Dance! To 'Dance': Distance and Digits." Computer Music Journal 25(1), p.13-20.

ENSEMBLE, Critical Art (2001). Distúrbio eletrônico, São Paulo: Conrad Editora, Coleção Baderna. Tradução de Leila Souza Mendes: "The eletronic disturbance".

FLUSSER, Vilém (2002). Filosofia da caixa preta, ensaios para uma futura filosofia da fotografia, Rio de Janeiro: Editora Relume Dumará.

FRANCIS, André (1987). Jazz, São Paulo: Martins Fontes. Tradução de Antonio de Padua Danesi.

GLUSBERG, J orge (1987). A arte da performance, São Paulo: Perspectiva, Coleção Debates. Tradução de Renato Cohen.

LAURENTIZ, Silvia (2004). Sobre "A montagem dos VJ s: entre a estimulação ótica e fisica" de Patricia Moran, Compós, texto inédito, São Paulo.

LÉVY, Pierre (1997). "Quatro obras típicas da cibercultura: Shaw, Fujihata, Davies". In A Arte no século XXI - A humanização das tecnologias, Diana Domingues (org) São Paulo: Editora UNESP, p.94-107.

LUCENA J r, Alberto (2002). Arte da animação - técnica e estética através da história, São Paulo: Editora Senac.

MACHADO, Arlindo (2000). A televisão levada a sério, São Paulo: Editora Senac. 
Papirus.

(1997). Pré-cinemas e pós-cinemas, Campinas: Editora (1988). A arte do vídeo, São Paulo: Editora Brasiliense.

MAKELA, Mia (2006). "Live Cinema: language and elements". MA in New Media at Helsinki University of Art and Design.

MELLO, Christine (2004). "Os Vjs e as imagens ao vivo, inacabadas, imersivas: 0 corpo em partilha com a obra". In: Corpo \& Tecnologia, Wilton Garcia (org), São Paulo: Editora U.N. Noj osa/ Senac.

"Imagens vivas" in http://p.php.uol.com. br/tropico/ html/ textos/ 1645, 1. shl, TRÓPICO, acesso em 24 de agosto de 2006.

MENOTTI, Gabriel (2007). "Através da sala escura. Dinâmicas espaciais de comunicação audiovisual - aproximações entre a sala de cinema e o lugar do VJing". São Paulo: Comunicação e Semiótica/ PUC, dissertação de mestrado.

"O contrário do cinema" in http://netart. incubadora.fapesp. br/ portal/ Members/ menotti/ rants/ wetware/03_ cinema/ ?searchterm=None, NET ART, acesso em 20 de janeiro de 2008.

MINARD, Robin (2002). "Musique concrète and its importance to the visual arts". In: Resonances: aspects of sound art, Bernd Schulz (org): Keher Verlag Heidelberg, p. 44-48.

MORAN, Patrícia (2004). A montagem dos VJ s: entre a estimulação ótica e a física, Compós - GT: Criação e Poéticas Digitais, Suzete Venturelli (coordenação), texto inédito, São Paulo.

(2003). "Rostilidades: os sentidos do rosto". São Paulo: Comunicação e Semiótica/ PUC, tese de doutorado.

PEACOCK, Kenneth (1988). "Instruments to Perform Color -Music: Two Centuries of Technological Experimentation". Leonardo 21 (4), p.397-406. 
POISSANT, Louise (2003). "Ser e fazer sobre a tela". In Arte e vida no século XXI: tecnologia, ciência e criatividade. Diana Domingues (org), São Paulo: Editora UNESP, p.115-123.

SPINRAD, Paul (2005). The VJ Book. Inspirations and pratical advice for live visuals performance, Los Angeles, Feral House.

TORDINO, Daniela (2003). "Império dos Sentidos". In Revista Simples, São Paulo: Wide Publishing, p.58-65.

VELÁZQUEZ, Fernando (2007). "Auto-retrato, o corpo desmaterializado". São Paulo: Moda, Cultura e Arte/ Centro Universitário Senac, dissertação de mestrado.

VIEIRA, Guilherme (2007). "O Visual J ockey e o hacking do vídeo". São Paulo: Escola de Comunicação e Artes/ USP, trabalho de conclusão de curso superior de audiovisual.

YOUNGBLOOD, Gene (1970). Expanded Cinema. NY: E.P. Dutton \& CO., Inc. 


\section{USTA DE FIGURAS}

Figura 1 VJ Alexis: remix de filmes no Skol Beats 2006.

(fonte: frame de vídeo institucional da Visual Farm)

Figura 2 VJ Spetto no Instituto Cultural Itaú, 2005.

(fonte: www. visualradio. com. br, em 20.jan.2008) 15

Figura 3 Proj eção de Palumbo.

(fonte: frame de vídeo - DVD VJ BR)

.16

Figura $4 \quad$ "Vermelho Sangue", de Duva.

(fonte: www. liveimages. com. br, em 20.jan. 2008). 17

Figura 5 Embolex no show do Afrika Bambaataa, Skol Beats 2007.

(fonte: www. youtube. com/ watch?v=VsE31kawtLY, em 20.jan. 2008). 18

Figura 6 Projeção do Bijari no Red Bull Live Images

(fonte: www. bijari.com. br, em 20.jan.2008).

Figura 7 "Dziga Vertov reenquadrado", do Feitoamãos/ FAQ

(fonte: www. sescsp. org. br/ sesc/ videobrasil/ site/ dossier013/ obras. asp,

em 20.jan. 2008)

Figura 8 "Arpoador", da Azóia Lab.

(fonte: frame de vídeo - DVD VJ BR) 20

Figura 9 Coletivo Desconstrução no Skol Beats 2007.

(fonte: imagem fornecida pelo VJ Erms, do Desconstrução) 
Figura 10 "Estofado robô felpudo", do projeto audiovisual ADDD.

(fonte: www.addd.com. br, em 20.jan.2008).

Figura 11 Apresentação do Laborg, Hipersônica 2006.

(fonte: http:// myspace. com/ laborg, em 20.jan. 2008).

Figura 12 Addictive TV mixa o filme "Cidade de Deus", no Mube, São Paulo.

(fonte: frame de registro em vídeo) .25

Figura 13 Clavilux - Thomas Wilfred, 1922

(fonte: www.iotacenter.org, em 20.jan.2008) 28

Figura 14 "Music Plays Images x Images Play Music" - Toshio Iwai e Ryuichi Sakamoto, 1966.

(fonte: www. aec. at/fleshfactor/flesh.html, em 20.jan. 2008).

Figura 15 "Pas de deux", de Norman McLaren.

(fonte: www. sensesofcinema.com/ contents/ cteq/ 05/ 35/ norman_mclaren. html, em 20.j an. 2008)

Figura 16 "Global Groove", Nam J une Paik, 1973.

(fonte: www. eai. org/ eai/ artist.j sp?artistID=481, em 20.jan. 2008)

Figura 17 "Uma idéia sem dono. Um coletivo sem estrela", projeção do Coletivo Virtual.

(fonte: www. youtube. com/ watch?v=vum2e_IQ8fk, em 20.jan. 2008). 36

Figura 18 "Tulse Luper Live Performance" no 16o Videobrasil, São Paulo". (fonte: http:// blogdovideobrasil. blog.uol.com. br/, em 20.jan. 2008)

Figura 19 Coletivo Desconstrução no show do DJ Erick Morillo, Brasília. (fonte: imagem fornecida pelo VJ Erms, do Desconstrução) 
Figura 20 Quadrilátero de projeção.

(fonte: frame de vídeo institucional da Visual Farm).

Figura 21 VJ Alexis e Visual Farm, Fonte do Pão de Açúcar, Parque do Ibirapuera.

(fonte: frame de vídeo institucional da Visual Farm) .43

Figura 22 Projeções do VJ Spetto no Royal Festival Hall, Londres.

(fonte: http:// blog. visual radio. com. br/ index. php?s=londres\&sbutt $\Rightarrow$, em 20.jan. 2008) .44

Figura 23 DVJ-1000, da Pioneer.

(fonte: www. pioneer. eu/ eur/ content/ press/ news/ dvj 1000. html, em 20.jan. 2008)......

Figura $24 \quad$ Interface do programa Isadora.

(fonte: www.troikatronix.com/ isadora.html, em 20.jan. 2008)

Figura 25 Interface do programa Modulat8.

(fonte: frame extraído do software). .48

Figura 26 "Performance-VJ ing-Wireless", da dupla "mm não é confete". (fonte: frame de vídeo - DVD VJ BR 55

Figura 27 "Poses do 19": de quem é a cadeira?

(fonte: frame do vídeo "Poses do 19"). 57

Figura 28 "Wild Life", de Karolina Sobecka.

(fonte: www.flightphase.com/ about.html, em 20.jan. 2008. 
Figura 29 "Super-Herói", de Regina Silveira.

(fonte: http:// reginasilveira.uol.com.br/ projecoes. php\#, em 20.jan. 2008).

Figura 30 "Laser Tag", do Grafitti Research

(fonte: www.graffitiresearchlab.com, em 20.jan.2008.

Figura 31 VJ Alexis/TEMP no Edifício

(fonte: www. videoguerrilha.com, em 20.jan.2008.

Figura 32 VJ Spetto, Alexis e Markus Dorninger "desenhando" com a TagTool. (fonte: www. fotolog.com/lalaisp/ 42534542, em 20.jan. 2008). 59

Figura 33 Interface do "Circ_lular/ mobil_izing", do Preguiça Febril.

(fonte: http:// pfebril.net, em 20.jan. 2008) 60

Figura 34 Apresentação do "Video Games Live"

(fonte: www. youtube.com/ watch?v=J VHGy9XEF9I, em 20.jan. 2008).....

Figura 35 "Tecnopathos", do Tecnopathos.

(fonte: imagem fornecida por Andréa Fraga)

Figura 36 "Desatino do Norte, Desatino do Sul", com o Bijari.

(fonte: www. bijari.com.br, em 20.jan.2008). 62

Figura 37 "SP_remix_2.0", de Fernando Velázquez, na exposição "Homens Trabalhando".

(fonte: www. blogart.com, em 20.jan. 2008). .63

Figura 38 "SP_Mobile", de Fernando Velázquez, Nacho Durán e Francisco Lapetina.

(fonte: imagem fornecida por Fernado Velázquez) 
Figura 39 "Self Cinema", de Vera Bighetti.

(fonte: www.artzero. net, em 20.jan. 2008)...

Figura 40 "De Vez em Sempre", de Giselle Beiguelman.

(fonte: www. desvirtual.com/ sometimes/ index.htm, em 20.jan. 2008)

Figura 41 Performance "m-u-r-o", no FILE 2007.

(fonte: imagem fornecida por Andrei Thomaz).

Figura 42 "Suspensão", de Duva.

(fonte: www. liveimages. com. br, em 20. jan. 2008). 
ANEXO

O DVD "VJing: imagens da cena" é um registro de performances de VJ $s$ realizadas em casas noturnas, festivais e eventos artísticos. Com o intuito de mostrar as apresentações em sua plenitude, o áudio original foi preservado.

Apresenta os seguintes conteúdos:

- Bijari e Kiko Ferraroni (Brasil)

Triângulo Music Telemig - set. 2005

Estádio J oão Havelange

Uberlândia

- Spetto e Kiko Ferraroni (Brasil)

Circuito 4 anos - out. 2005

Espaço M

São Paulo

- Bijari, Spetto, Akira, Nirvana, Kiko Ferraroni (Brasil)

TIM Festival - out. 2005

MAM

Rio de J aneiro

- News (Holanda)

Agosto 2006

Club 11

Amsterdã

- Addictive TV (Reino Unido)

Motomix - set. 2006

Mube

São Paulo

- Modeselektor (Alemanha)

Motomix - set. 2006

Espaço das Américas

São Paulo

- Peter Greenway (Reino Unido)

Tulse Luper Live Performance

Videobrasil - set. 2007

Sesc Paulista 